Historic, Archive Document

Do not assume content reflects current scientific knowledge, policies, or practices. 

䓞

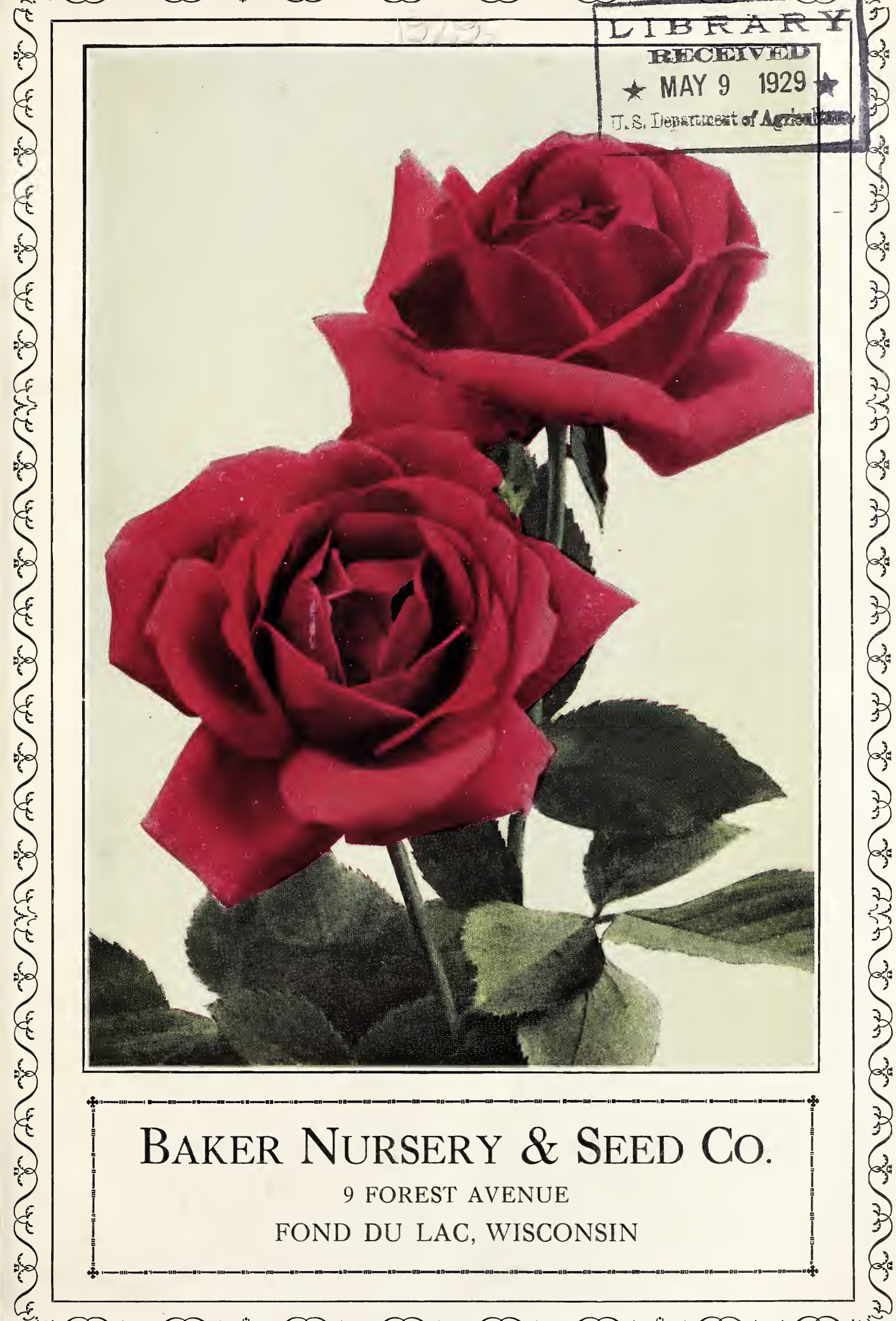

"थ 


\section{EIGHT POPULAR SHRUBS}
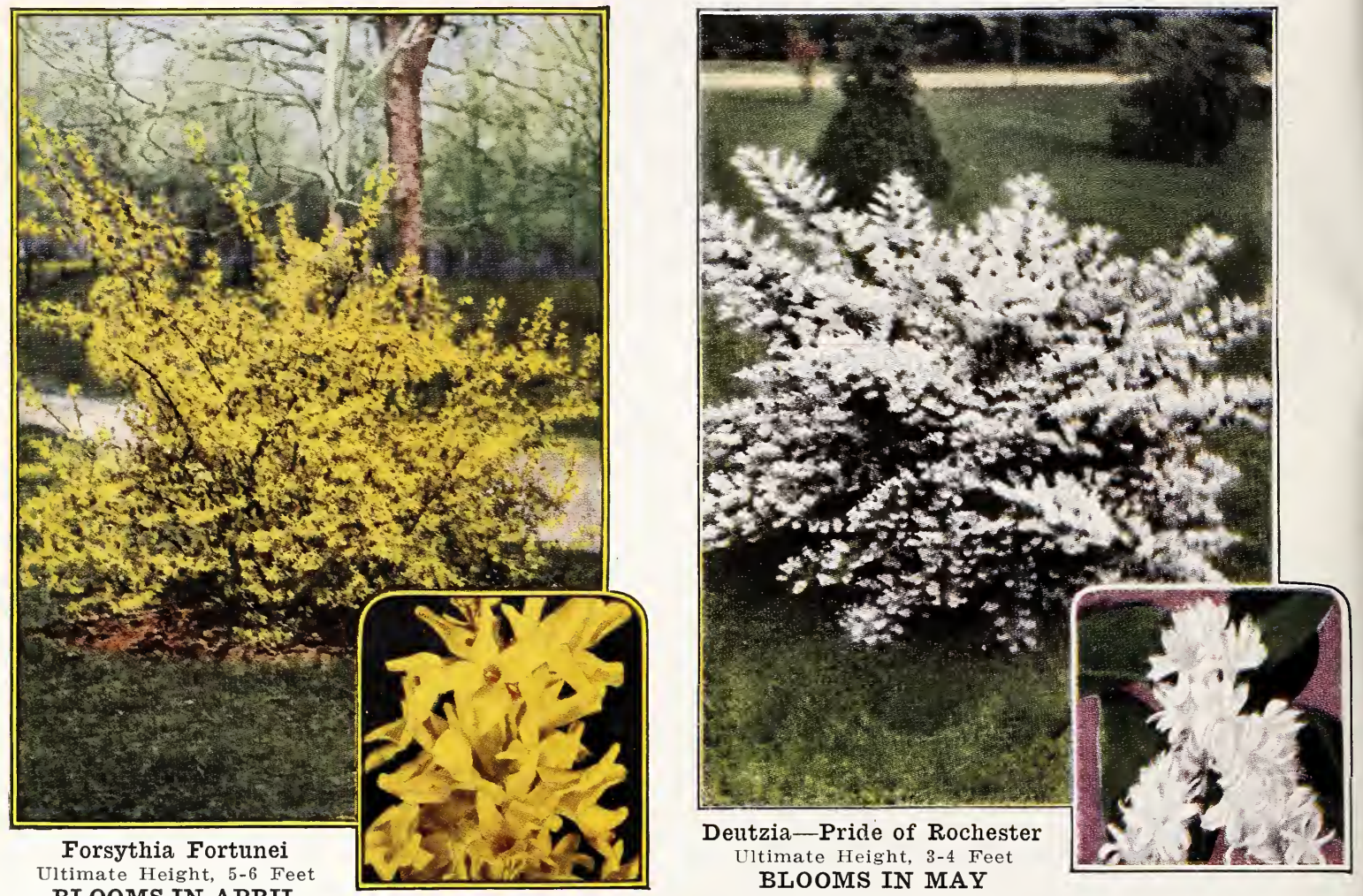

BLOOMS IN APRIL

BLOOMS IN MAY

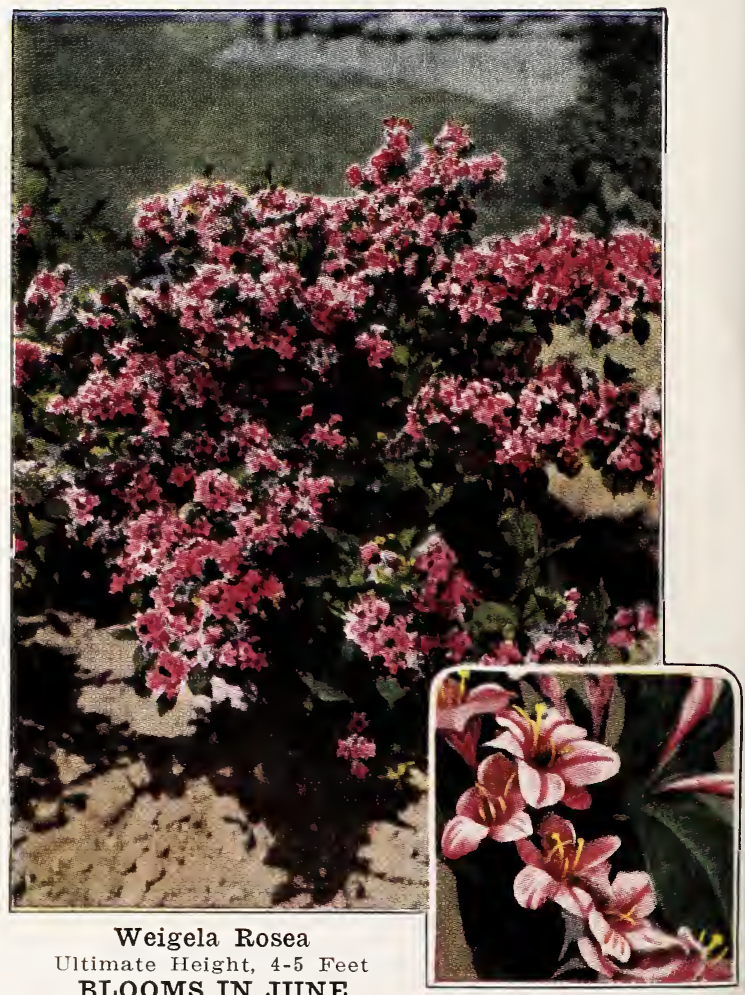

Refer to Page 12 for Planting Plans for These 8 Shrubs. 


\section{Dignity and Beauty Are Expressed in These Simple Items}

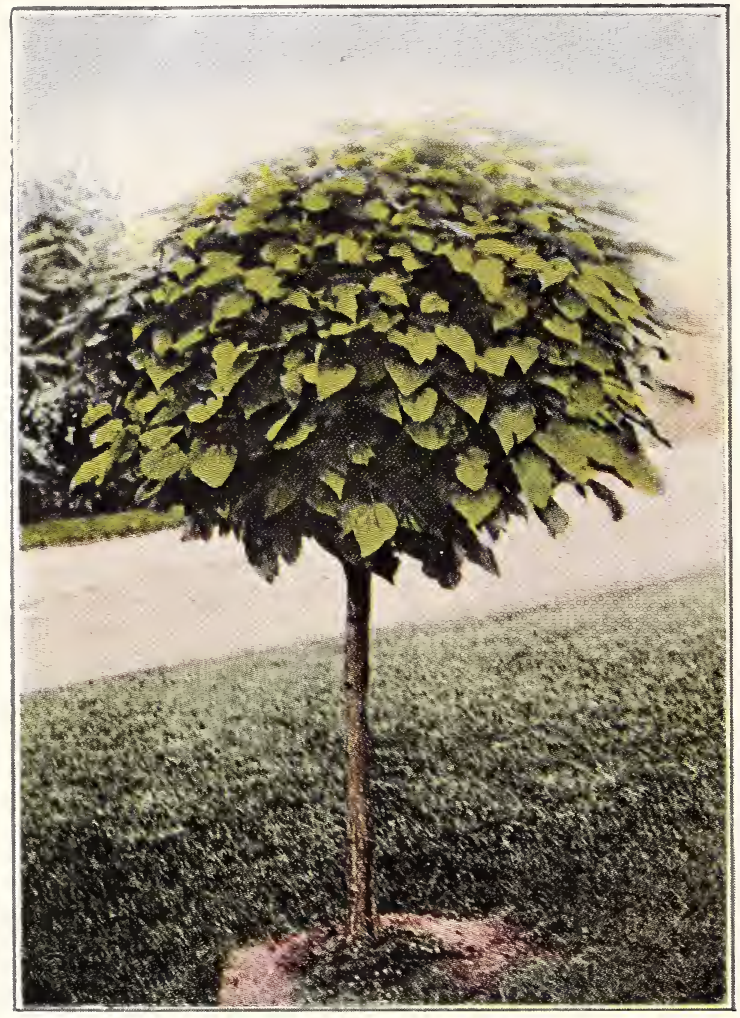

CATALPA BUNGEII-Catalpa bignonioides, var. nana or Bungeii. For formal planting, generally used in pairs. Refer to page 23.

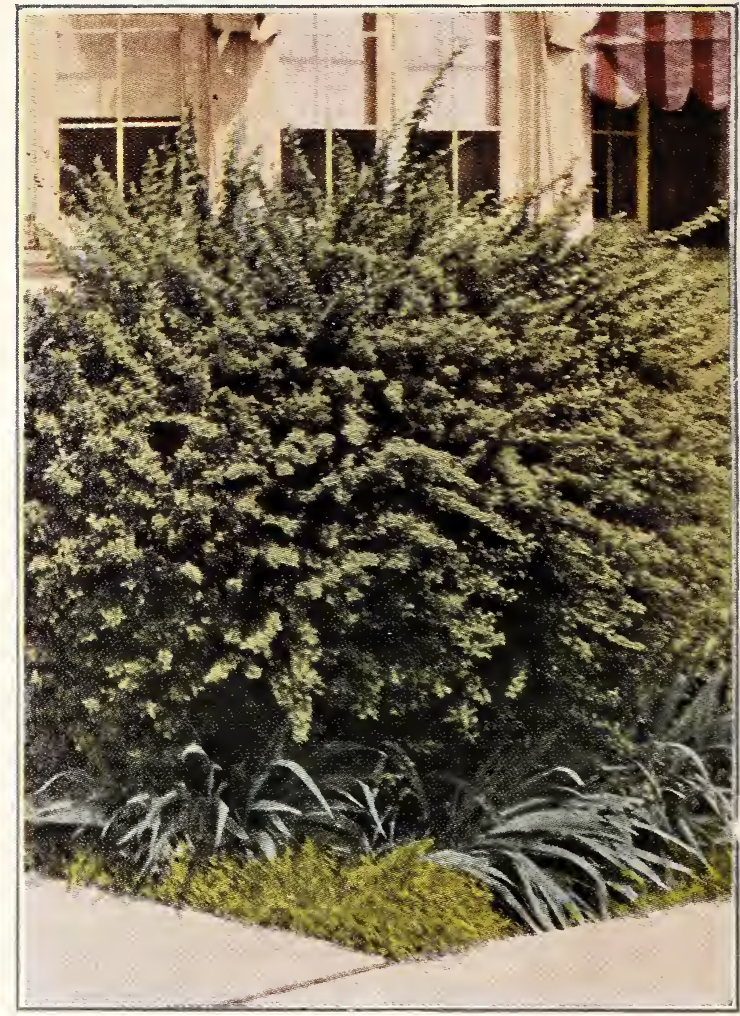

JAPANESE BARBERRY-Berberis Thunbergii. Makes an excellent hedge, either natural or formal. Flowers in June; scarlet berries in fall and winter. Refer to page 15.

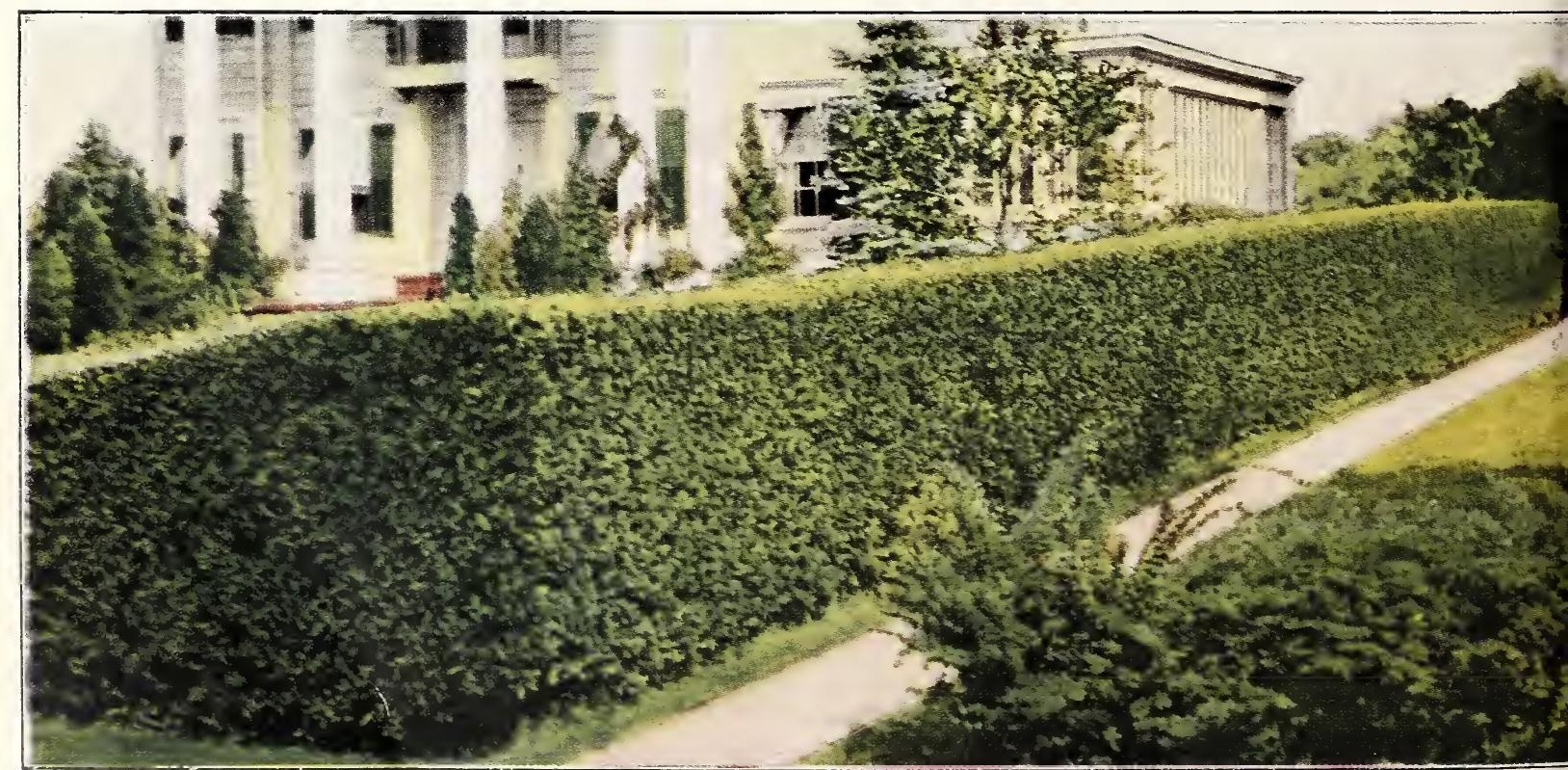




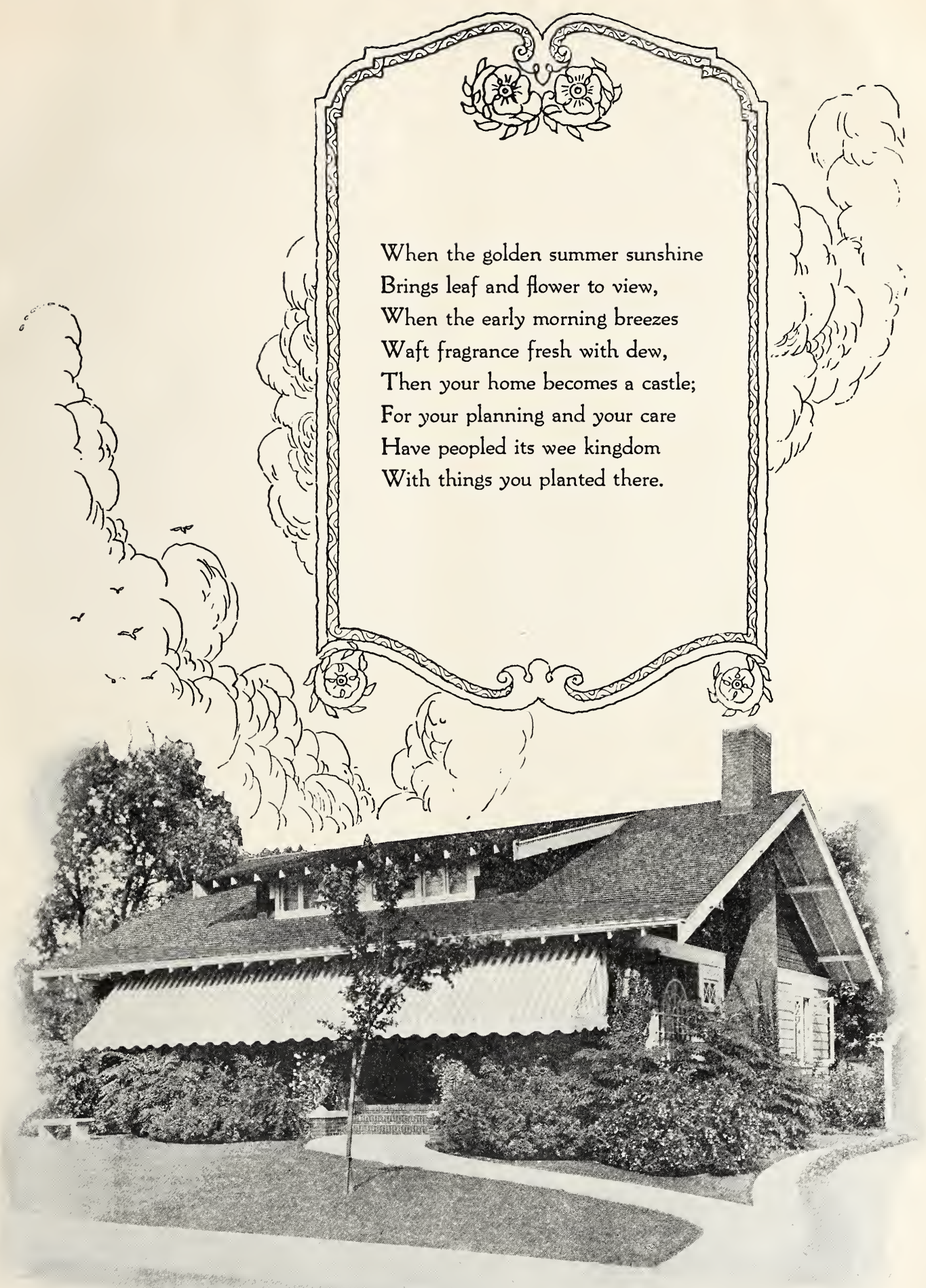




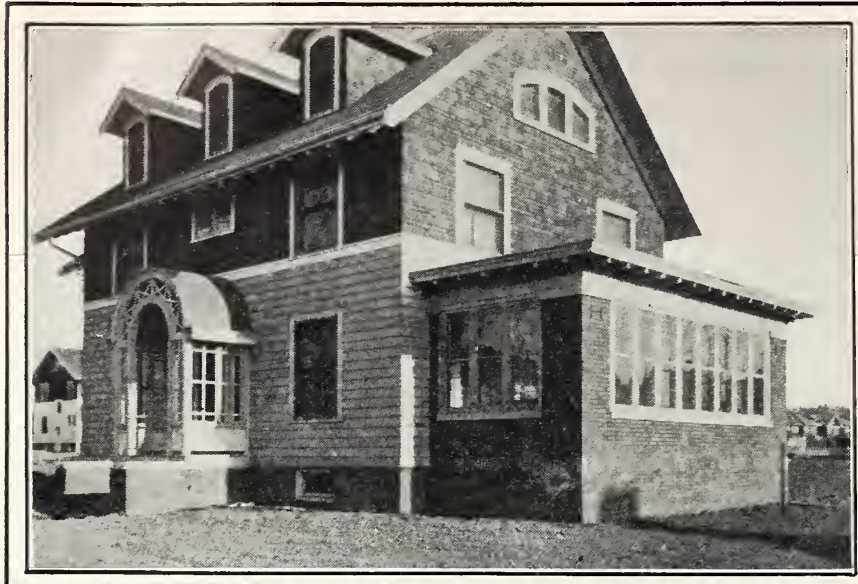

What a difference a few shrubs make. Two pictures of the same house-one bare, un. finished, uninviting - the other a picture of tasteful planning that reflects an enjoyable homelife within.

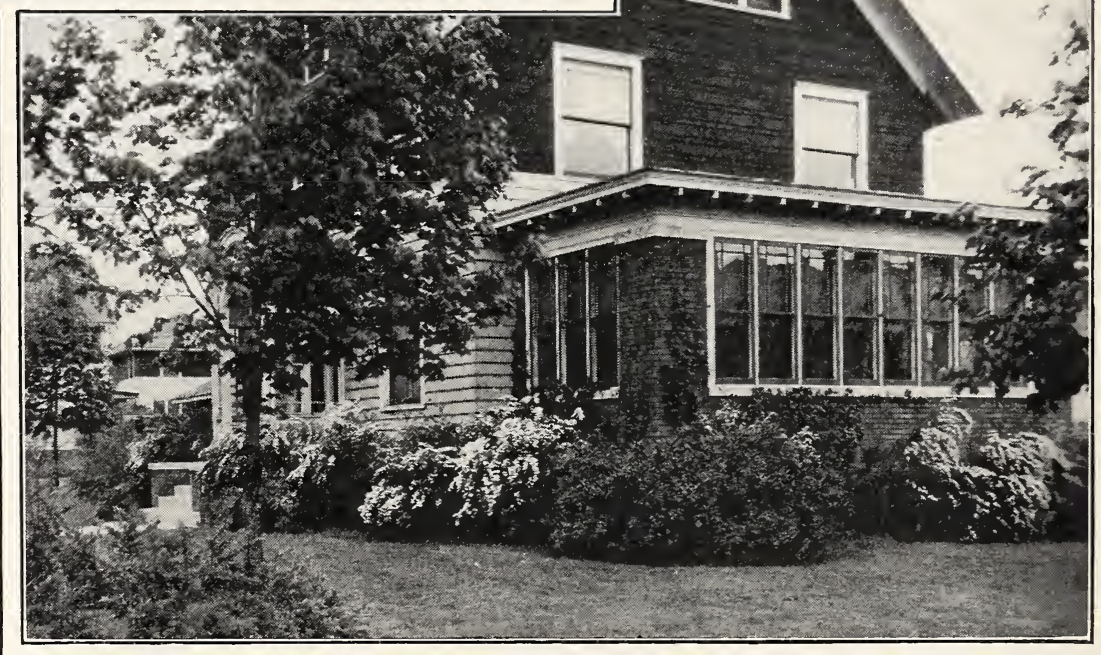

Ho

OMEMAKING does not end with building a house and furnishing the interior. The grounds, too, must be furnished with trees and shrubs to beautify the surroundings - to blend stark foundation lines with the lawn-to lend that air of permanency and contentment that makes a really delightful home. All the planting plans in this book were prepared by experienced landscape Nurserymen. Select one suitable to your own home and let us supply the materials required. You will be delighted with the results.

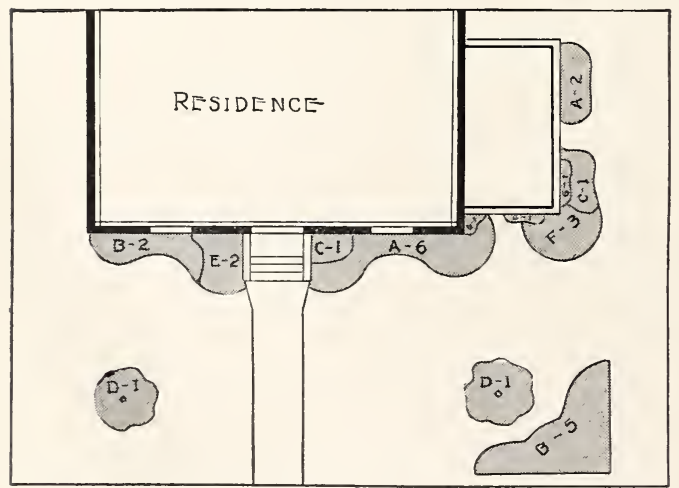

List of Shrubs and Planting Plan
A 8 Spirea Van Houttei
B 7 Barberry Thunbergii
C. 2 Snowberry
D 2 Maple Trees
E 2 Bush Honeysuckle
F 3 Deutzia-Pride of Rochester
G 3 Vine Ampelopsis 


\section{Practical Landscape Designs}

Suitable shrub types in selected varieties, assigned to particular locations against the various foundation facings of typical modern houses. The next preceding pages direct exact computation of quantities. Best quality stock in normal shipping sizes is considered in the succeeding plans, which you can order by number.

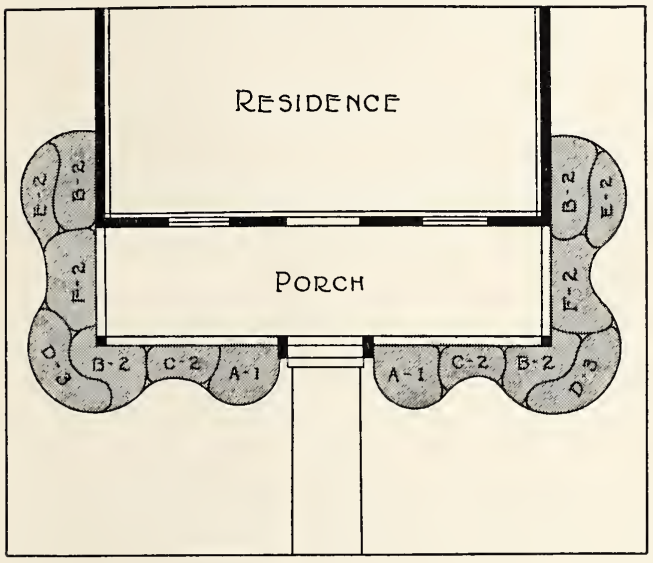

\section{PLAN No. 1 WITH THE PORCH}

Whether this porch is covered or merely a terrace, the planting characteristics would correspond. The tall types are at the corners; the steps are treated both sides alike.

No.

SUNNY:

Plants Color Bloom

A-2 Honeysuckle Morrowii . . White May-June

C-8 Snowberry Houttei : : : White May-June

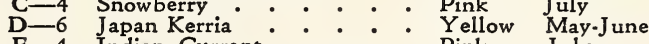

E-4 Indian Currant

\section{SHADED:}

A-2 Honeysuckle Morrowii . . White May-June

B-8 Regel's Privet . . . : White June-July

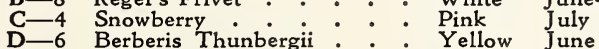

D-6 Berberis Thunbergii . . Yellow June

$\begin{array}{ll}\text { E-4 } & \text { Indian Currant } \\ \text { F-4 } & \text { Snowberry . : : : Pink July }\end{array}$

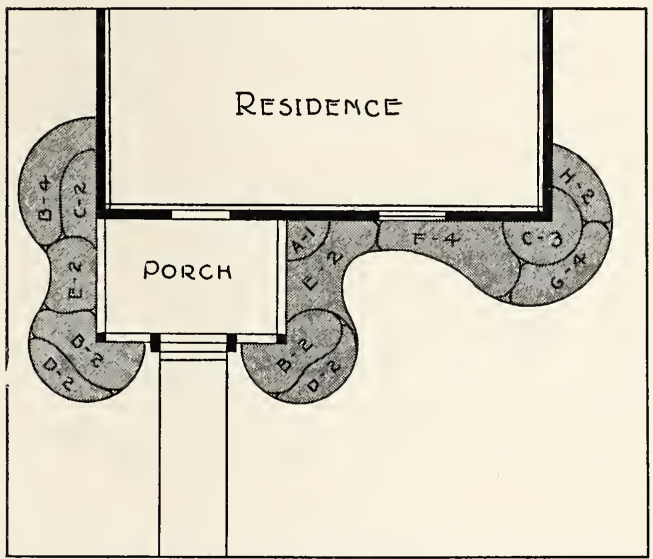

\section{PLAN No. 2 PORCH PART WAY}

A balanced entity, although focused on the off-side porch.

No.
Plants
A-1
B-8
C-5
D-4
E-4
F-4
H-4
H-2

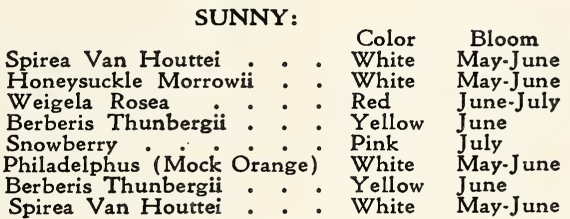

SHADED:

\begin{tabular}{|c|c|c|c|c|}
\hline $\begin{array}{l}\mathrm{A}-1 \\
\mathrm{~B}-8 \\
\mathrm{C}-5 \\
\mathrm{D}-4 \\
\mathrm{E}-4 \\
\mathrm{~F}-4 \\
\mathrm{G}-4 \\
\mathrm{H}-4\end{array}$ & $\begin{array}{l}\text { Dogwood } \\
\text { Honeysuckle Morrowi } \\
\text { H. B. Cranberry } \\
\text { Berberis Thunbergii } \\
\text { Snowberry } \\
\text { Indian Currant } \\
\text { Berberis Thunbergii } \\
\text { Snowberry }\end{array}$ & & : & $\begin{array}{l}\text { White } \\
\text { White } \\
\text { White } \\
\text { Yellow } \\
\text { Pink } \\
\text { Pink } \\
\text { Yellow } \\
\text { Pink }\end{array}$ \\
\hline
\end{tabular}

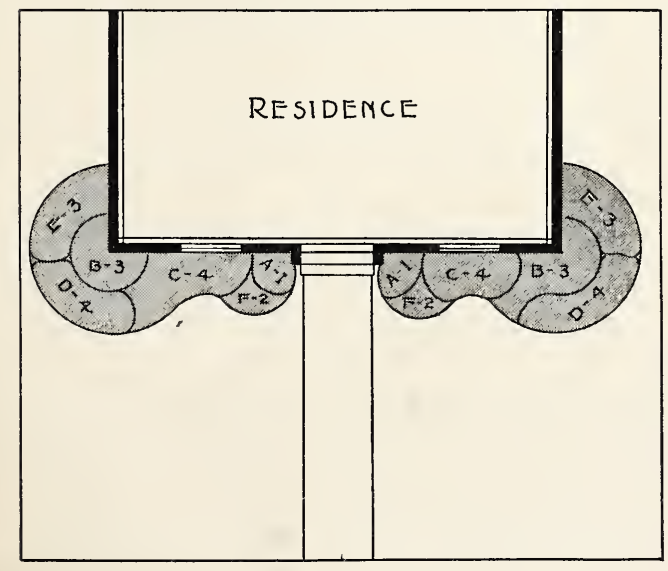

\section{PLAN No. 3 DOOR IN CENTER.}

Conventional colonial type-no porch, entrance door at center. Being so balanced, the door is the dominant feature emphasized by tall planting. Both sides should be alike; the outside corners also tall, the connecting lines comparatively low.

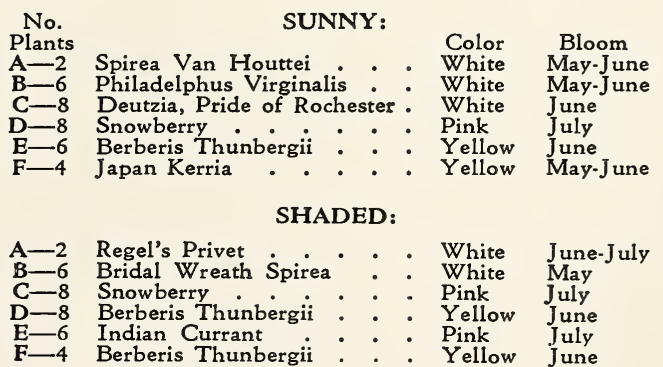




\section{Practical Landscape Designs}

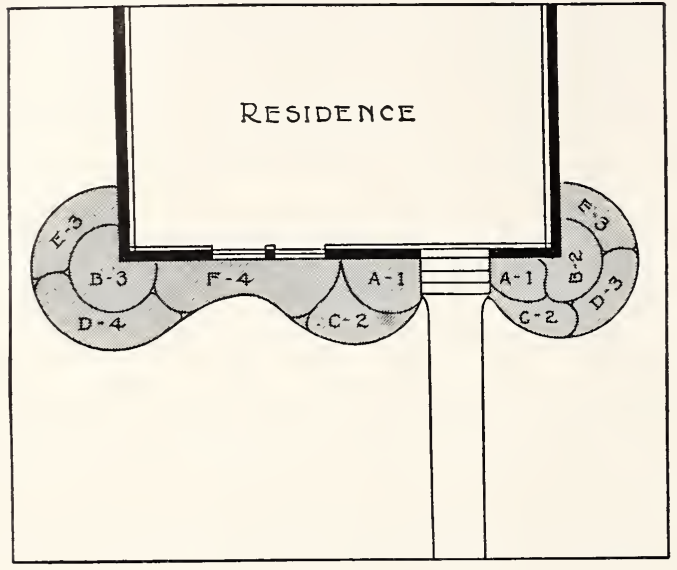

\section{PLAN No. 4 NO FRONT PORCH.}

Similar to No. 3 except the door is to left or right of center, creating an unsymmetrical problem which is perhaps one of the most awkward and difficult to properly landscape: We believe our layout successfully covers the situation.

No.
Plants
A-2
B-5
C-4
D-7
E-6
F-4

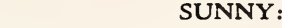

Plants
B-2
C-4
D-7
E-6
F-4 Spirea Van Houttei . . . White Weigela Rosea . . • . . Red Japan Kerria • $\cdot * \cdot$ : Yellow Berberis Thunbergii June-July

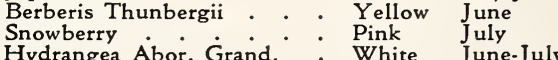

\section{SHADED:}

A-2 Honeysuckle Morrowii . . White May-June

B-5 Cornus Siberica . . : White May

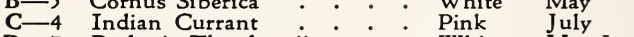

D-7 Berberis Thunbergii : $:$ White May-June

E-6 Indian Currant . . . . Pink July

Snowberry $\cdot \cdot \cdot \cdot \bullet^{\circ}$ Pink July

\section{PLAN No. 5 HOUSE WITH A}

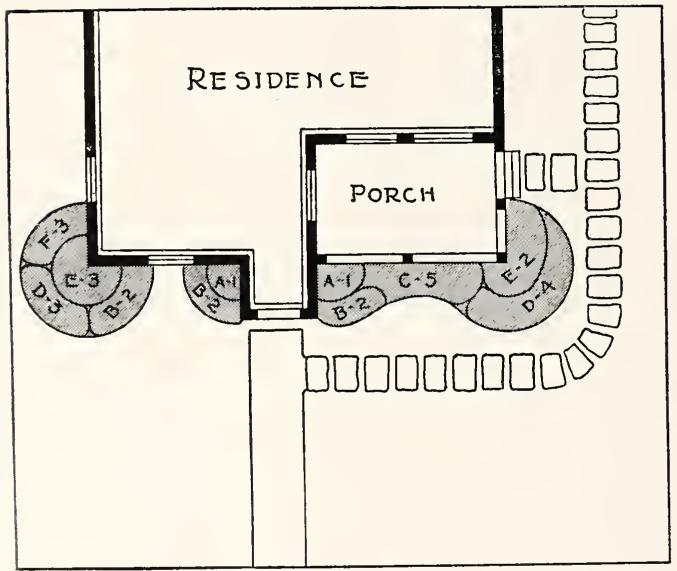

This plan presents a pleasingly balanced effect; although the open recessed porch requires low-growing shrubs so as not to interrupt vision, while the house proper beyond the door has wall space allowing a higher growth. This type can be treated successfully in widely varied combinations.

No.

Plants

A-2

C-5

D-5

F-5

A-2. Regel's Privet

B-

D-5

Pink July

F-3 B. B. Cranberry . . White May-June

. . . White May-June

\section{SHADED:}

\section{PLAN No. 6 CENTRAL FRONT DOOR.}

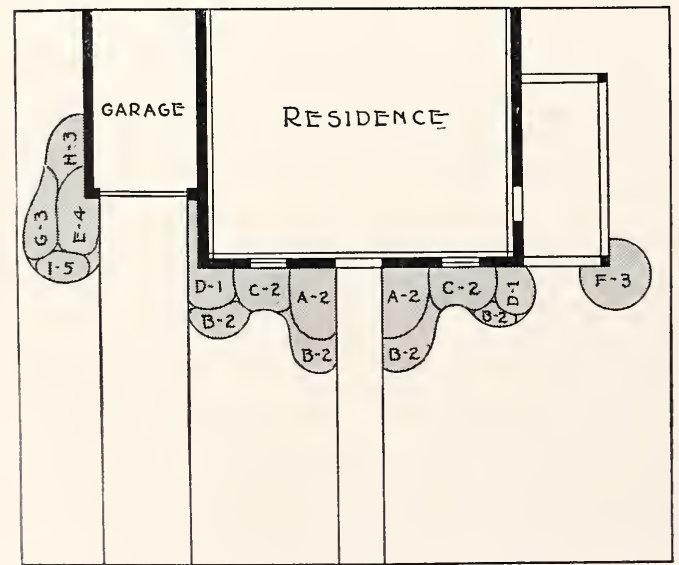

A house of this type requires quite symmetrical treat ment each side of the central door, with a variation at either end where Garage and Porch express different characteristics.

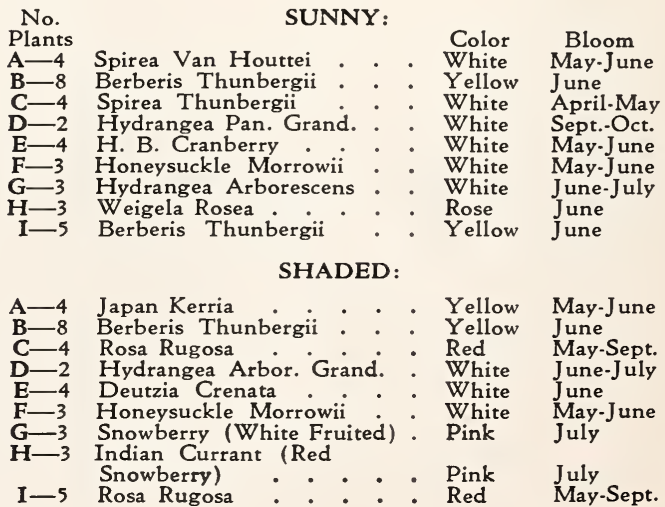




\section{Practical Landscape Designs}

\section{PLAN No. 7 THE HOUSE WITH A}

In considering this plan, it must be borne in mind that a rear planting is absolutely opposite as to sun or shade to the front, and must be given the alternative selection of material. In small back yards, as in small front lawns, it is best to confine the plantings to compact groups against the building, rather than to spread them out here-and-there without correlation.

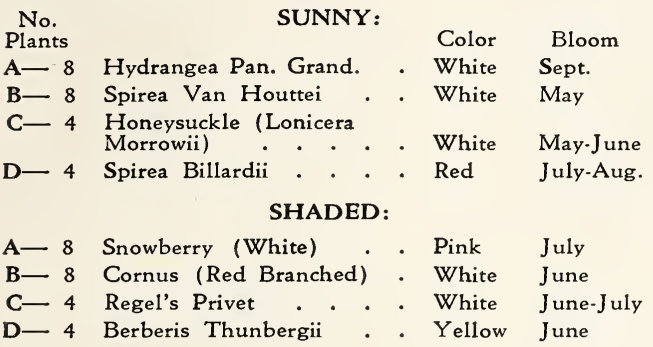

\section{PLAN No. 8 SMALL UNCOVERED}

This rear-door condition is prevalent, where the small, raised, uncovered platform near one corner leads directly to the kitchen. You will note wc establish the tallest shrubs at he with the medium and low-growing types. This is necessary with the medium and low-growing types. This is necessary for proper balance, the porch structure otherwise creating an
over-prominent heaviness. In Plan No. 10, you will find a variation to take care of this porch when covered.

No.

Plants

SUNNY:

Color Bloom

B-16 Berberis Thunbergii . . Yellow June

C- 2 Japan Kerria . . . Yellow May-June

D- 4 Spirea Van Houttei . . White May-June

E- 3 Spirea, Anthony Waterer . Red July-Aug.

\section{SHADED:}

A- 1 Honeysuckle Morrowii . . White May-June

B-16 Berberis Thunbergii . . Yellow June

C- 2 Regel's Privet . . . . White June-July

D- 4 Spirea Van Houttei . . White May.June

E- 3 Rosa Rugosa . . . . Red May-Sept.
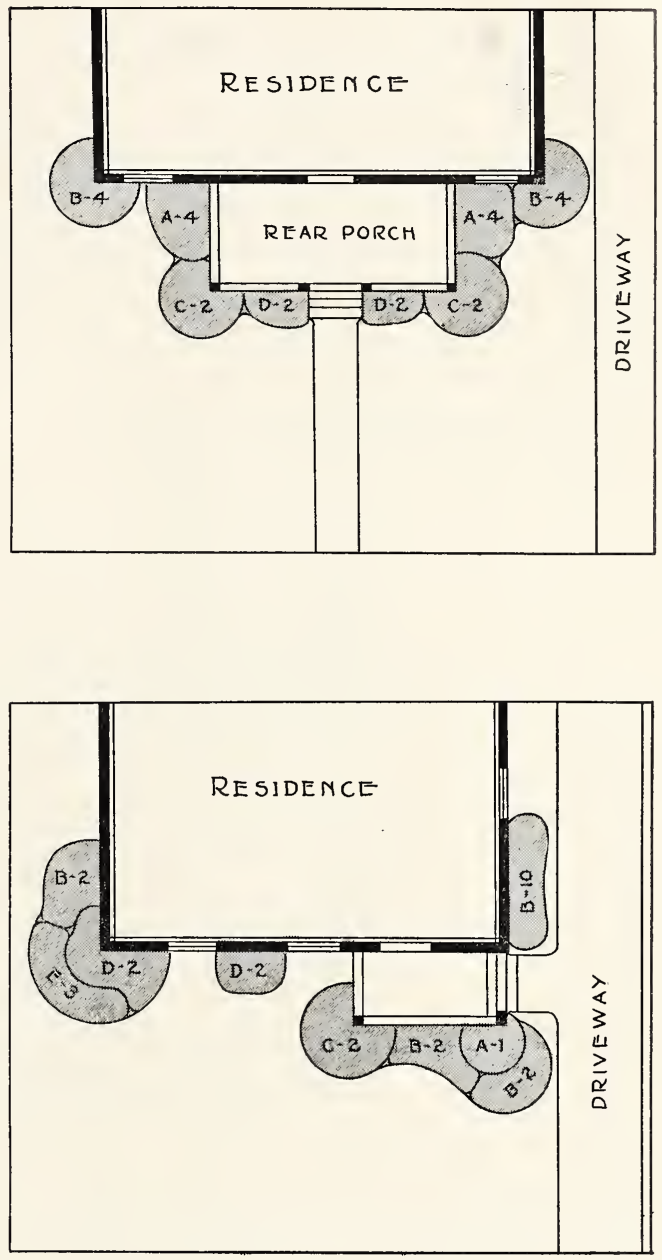

\section{PLAN No. 9 THE HOUSE WITH}

The utility of the house plan is obvious in the picture, but ornamentally its landscaping is particularly adapted to mergence with the scheme outlined in No. 12, for converting the back yard into a well shaded, leafy, secluded outdoor living room. In this case, no planting should be door living room. In this case, no planting should be lawn, unless it be a low clipped hedge. As illustrated, the planting masses against the house itself, are confined to the outer corners; thus balancing the entire area.

No.

Plants

A- 4 Spirea Van Houttei . . White

B- 6 Weigela Rosea . . Rose

C- 6 Spirea Anthony Waterer . Red

D-10 Snowberry (White) . . Pink

\section{SHADED:}

A- 4 Spirea Van Houttei . . White

B- 6 Snowberry (White) . . Pink

C- 6 Rosa Rugosa Rubra . . Red

D-10 Indian Currant (Red

Snowberry)
Pink
Bloom

June-July

June

July-Aug.

July

June-July July

May-Sept.

July

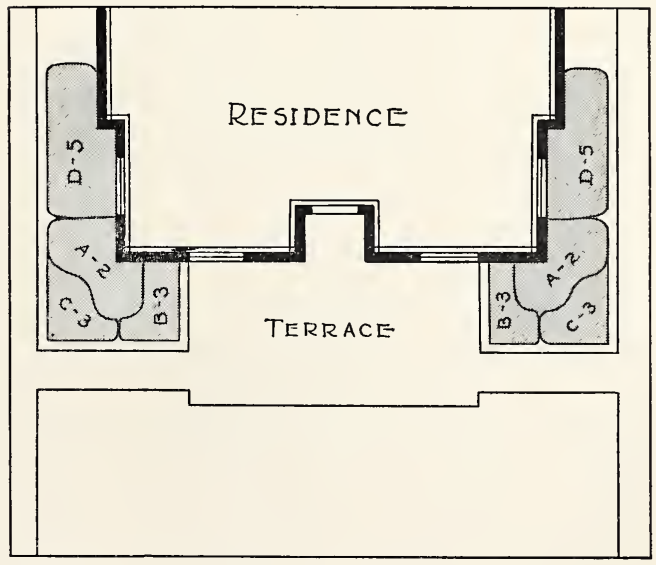




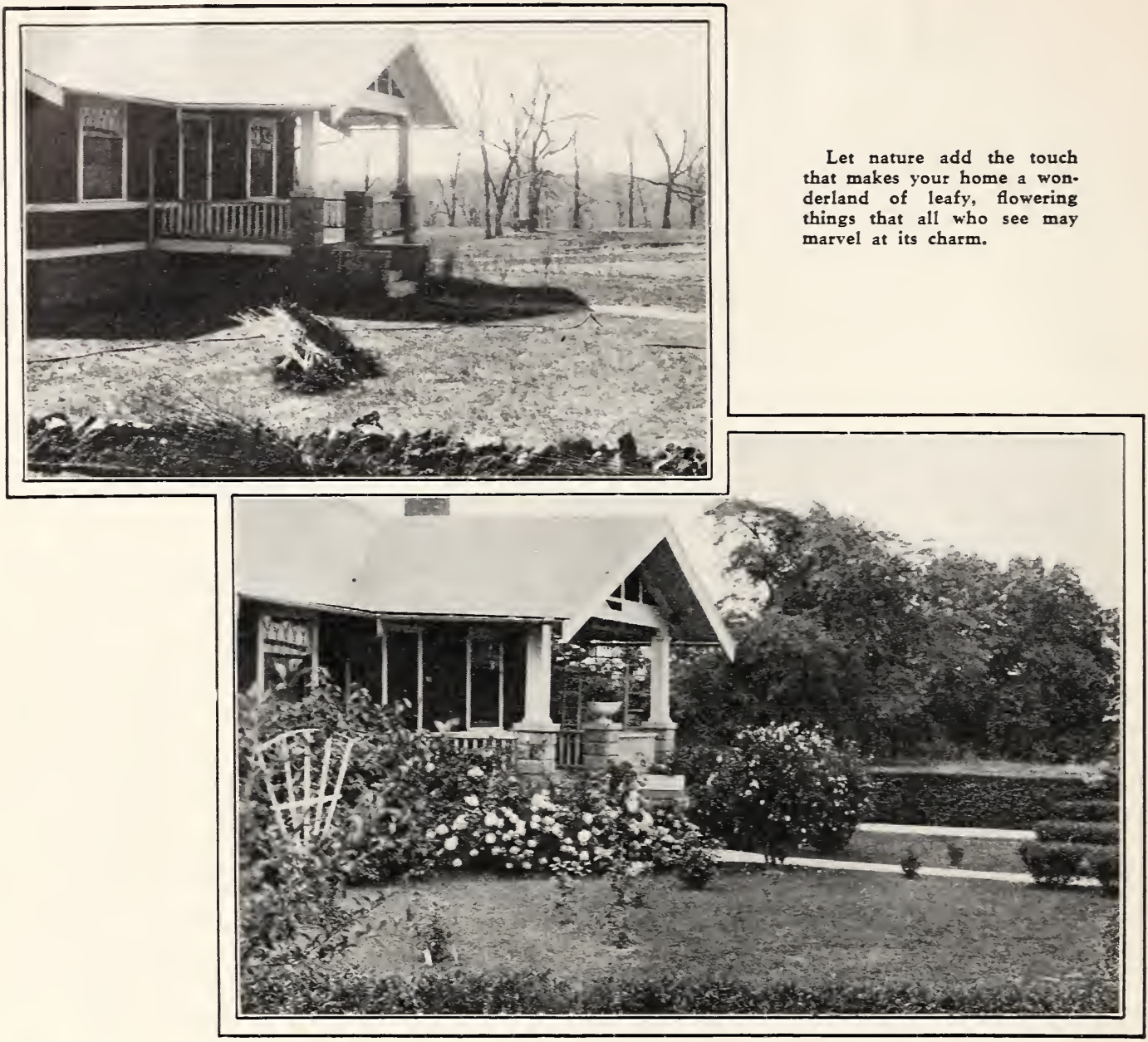

$P$

LANTING the home surroundings should be planned and provided for as any other necessity of a well ordered home. In the foreground of the top picture is shown the bundled shrubs ready for setting out according to a planting plan like the one shown below. Every shrub strong, healthy and sure of vigorous growth. Don't buy a shrub here and there with questionable results. Use only guaranteed nursery stock and your success is assured.

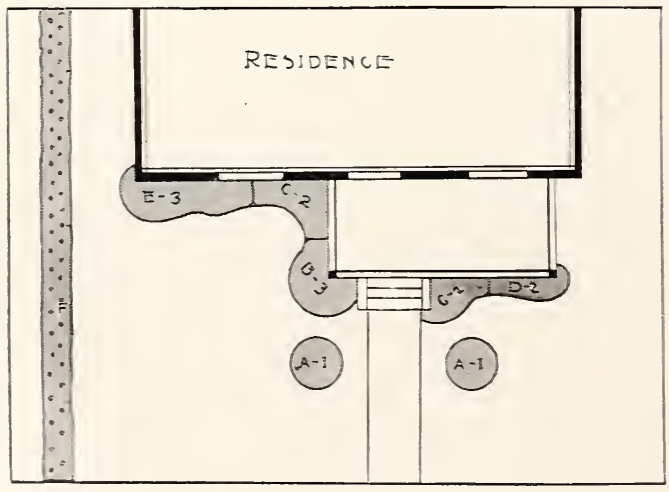

\section{List of Shrubs and Planting Plan}
A 2 Rose of Sharon
B 3 Hydrangea P. G.
C 4 Red Branched Dogwood
D 2 Honeysuckle
E 3 Viburnum Dentatum
F California Privet Hedge

$10^{\prime \prime}$ apart, double row 


\section{Practical Landscape Designs}

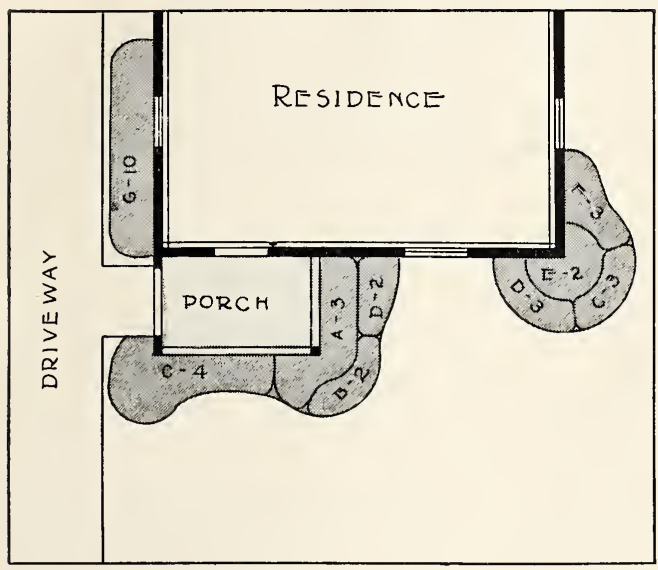

\section{PLAN No. 10 WITH SMALL COVERED}

Here is a covered rear porch, similar to No. 8 as to location, but differently treated on account of the covering. The principles featuring the other layout maintain here as well; the addition of vines on porch being quite allowable.

No.

SUNNY:

Plants
A- 3
B二 2
C二 7
DE 5
E- 2
F二 3
G-10

Color Bloom

- 3 Philadelphus Virginalis - White May-June

- 7 Spirea Billardi $\vdots \vdots \vdots$ Red July.Aug.

- Snowberry (White Fruited) Pink July

F- 3 Philadelphus (Mock Orange) White May.June

-10 Regel's Privet . . . White June-July

\section{SHADED:}

A- 3 Bridal Wreath Spirea . White May

B- 2 Berberis Thunbergii - Yellow Jun

C- 7 Rosa Rugosa Rubra Red May-Sept.

D二 5 Snowberry (White Fruited) Pink July

E- 2 H. B. Cranberry . . White May-June

F- 3 Indian Currant (Red . . Pink July

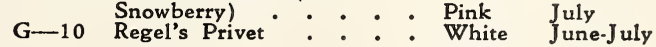

\section{PLAN No. 11 REAR PORCH AND}

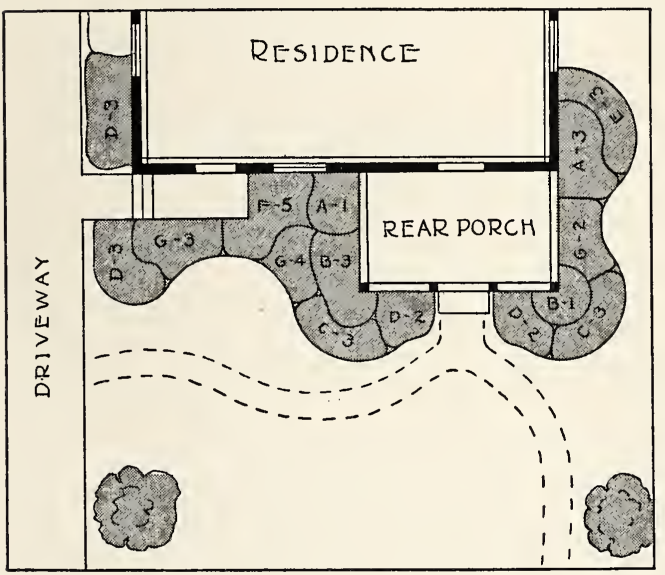

In this case, the taller plants are located against the building, with the medium and dwarf types planted about them; thus saving the vertical lines of the house. Broken stone paths are artistic as well as useful, their location regulated by objectives to be reached.

No.

SUNNY:

Plants

- 4 Spirea Van Houttei Color Bloom

$\begin{array}{ll}\text { A- } 4 & \text { Spirea Van Houttei } \\ \text { B- } 4 & \text { Forsythia Fortunei } \\ \text { C- } 6 & \text { Philadelphus (Mock }\end{array}$

C- 6 Philadelphus (Mock

D-10 Orange) - $^{\circ} \dot{0}^{\circ}$ - White May-June

E-10 Berberis Thunbergii * Yellow June

E- 3 Spirea Anthony Waterer - Red July-Aug.

G- 9 Hydrangea Pan. Grand. - White Sept.-Oct.

\section{SHADED:}

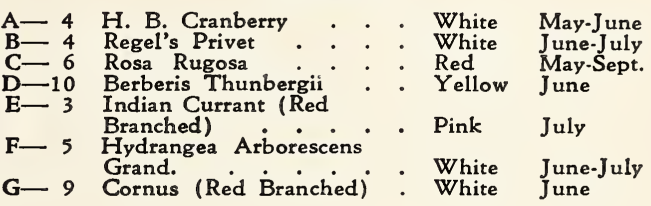

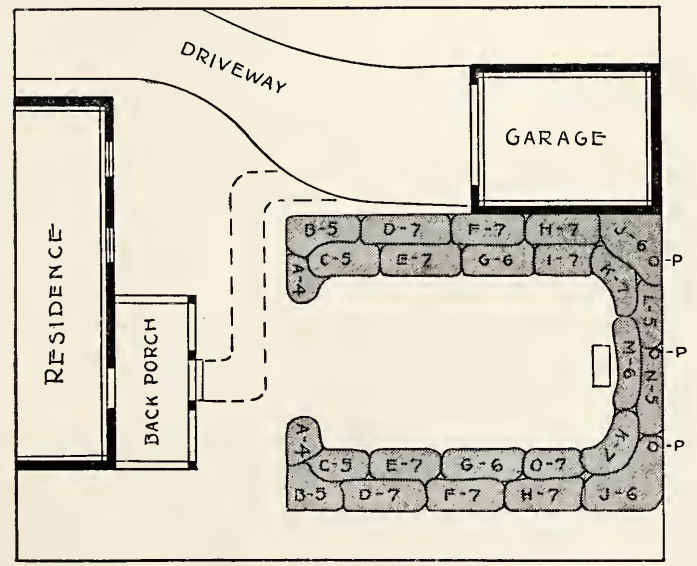

\section{PLAN No. 12 THE BACK YARD AS AN}

This planting serves not only to delight the eye, but the tall-growing outer fringe effectually screens from view possibly obnoxious neighboring conditions; throws refreshing summer shade, and maintains a desirable privacy for enjoyment by your family. The inner lines inject bright color and piquant foliage types; and being of low growth, add to variety without detracting from your complete view. No.

Plants
A- 8
B-10
C-10
D-14
E-14
F-14
G-12
H-14
I- 7
J-12
K-14
L- 5
M- 6
N- 5
D- 7
P- 3

Berberis Thunbergii

\section{Spirears Thunb}

Weigela (Eva Rathke)

Weigela Rosea

Spirea Anthony $\dot{W}$ aterer

Tartarian Honeysuckle

Rosa Rugosa Rubra

Forsythia Fortunei . .

Deutzia, Pride of Rocheste

Common Purple Lilac.

Rhiladelphus Virginalis

Spirea Van Houttei

H. B. Cranberry

Deutzia Lemoinei :

Lombardy Poplar (10 to

\section{Color Bloom}

Yellow June

White June

Crimson June-July

Pink June

Crimson July-Aug.

Pink May-June

Red May-Sept.

Yellow April

White June

Purple May

White June-July

White May-June

White June-July

White May-June

June 


\section{Shrubs that Bloom Throughout the Summer}

A few planting plans calling for only eight varieties of Flowering Shrubs, whose succession of bloom will mean floral display from April to October. See them in full color on inside front cover.
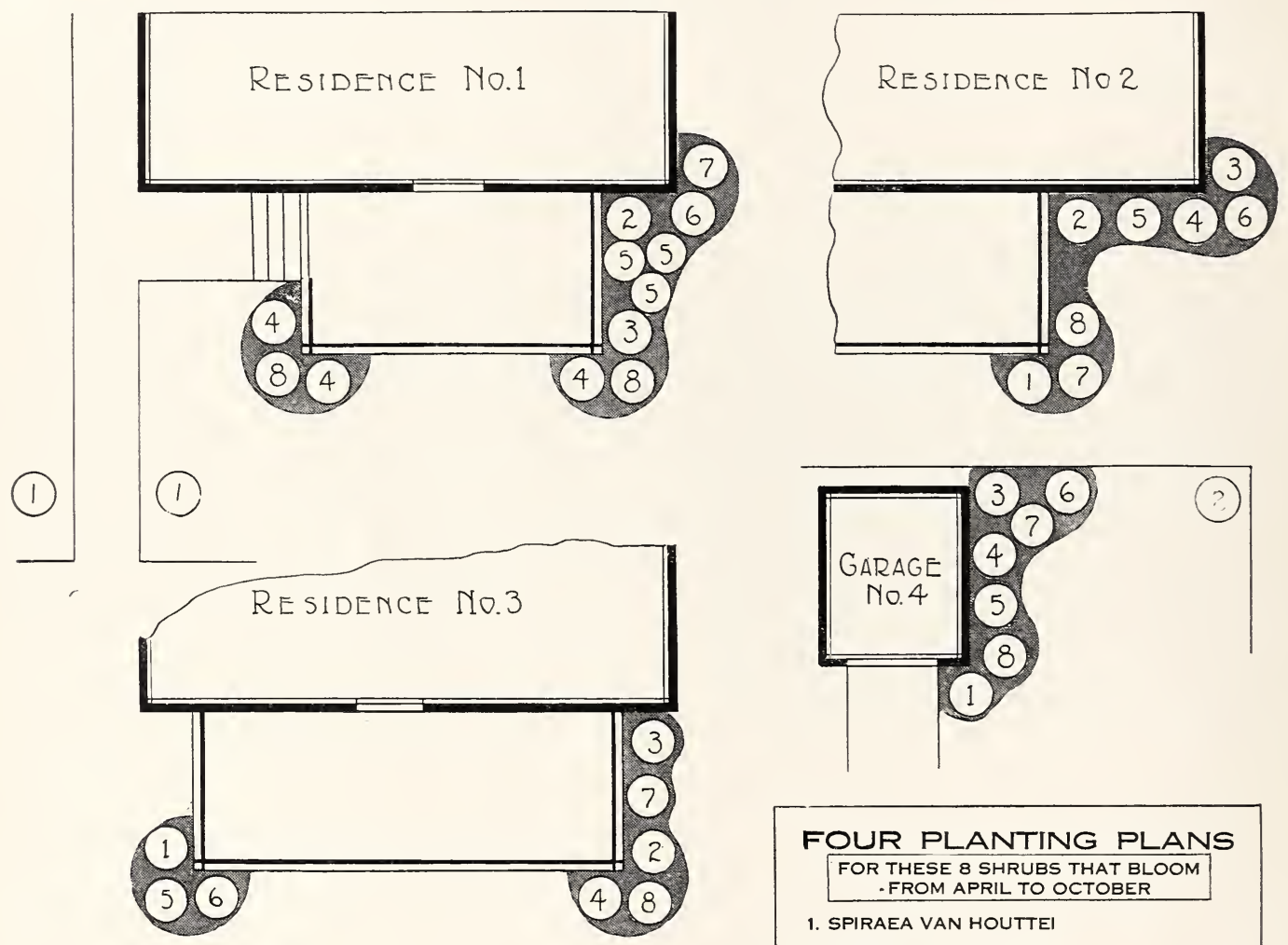

\footnotetext{
FOUR PLANTING PLANS FOR THESE 8 SHRUBS THAT BLOOM -FROM APRIL TO OCTOBER

1. SPIRAEA VAN HOUTTEI

2. FORSYTHIA FORTUNEI

3. DEUTZIA PRIDE OF ROCHESTER

4. SYRINGA MOCK ORANGE

5. HYDRANGEA P. G.

6. TARTARIAN HONEYSUCKLE

7. SPIRAEA ANTHONY WATERER

8. WEIGELA ROSEA
}

Plan No. 1 embraces the same eight varieties, but duplicates certain items for a more extended display.

Plans Nos. 2, 3 and 4 require only one each of the eight varieties of flowering shrubs listed in this special collection. 


\section{Practical Perennial Planting Plans}

Prepared by Landscape Architect to aid you in getting a well balanced showing, both as regards variety of colors and duration of bloom.

PLAN No. 30

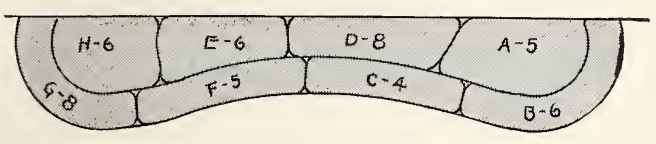

SUGGESTION No. 1

\section{A-5 Coreopsis}

B-6 Sweet William

C-4 Shasta Daisy

D-8 8 Larkspur

E-6 Foxglove

E-6 Foxglove

F-5 Pyrethrum

$\mathrm{G}-8$ Columbine
SUGGESTION No, 2

A-5 Phlox-in variety

B-6 Gaillardia

C-4 Pinks (Dianthus)

D-8 Foxglove

E-6 Larkspur

F-5 Shasta Daisy

G-8 Achillea

\section{PLAN No. 31}

SUGGESTION No. 1

\section{A-6 Pinks (Dianthus)}

B-4 Pyrethrum

D-6 Sweet William-in variety

F-4 Veronica (Bluebird Flower)

G-6 Shasta Daisy

H-4 Larkspur

$\mathrm{J}-4$ Achillea

\section{SUGGESTION No.}

A-6 Candytuft

B-4 Shasta Daisy

D-6 Gaillardia (Blanket Flower)

E-2 Foxglove

F-4 Larkspur

G-6 Sweet William-in variety

$\mathrm{H}-4$ Phlox-in variety

I-6 Veronica (Bluebird Flower)

J-4 Chrysanthemum - in variety
E-2 Aconitum (Monkshood)

I-6 Phlox-in variety

C-6 Coreopsis

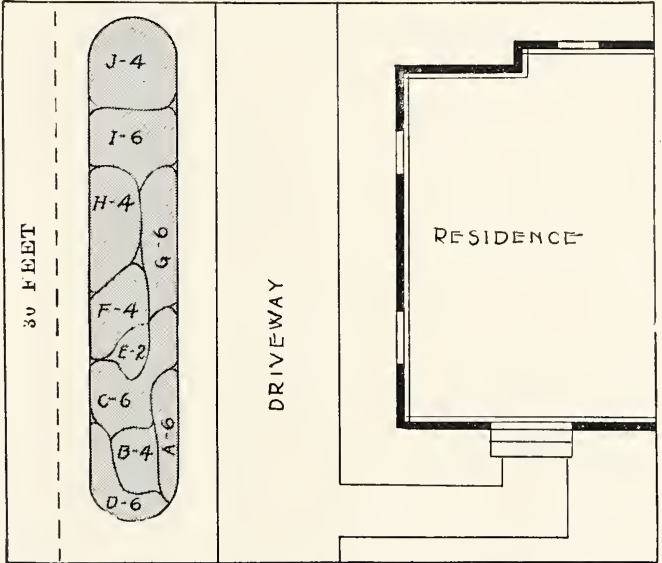

\section{Convertible Planting Plan No. 33}

Two oblong shapes $4 \times 20$ feet, form the basis of this plan and they may be employed in a variety of ways in 1 a y ing out the Perennial Garden.

SUGGESTION No. 1

A-1 Hypericum

B-2 Coreopsis

C-3 Hollyhock-in var.

D-4 Sweet William-

in variety

E-3 Foxglove

(Blanket Flower)

G-4 German Iris-in var.

H-4 Aconitum (Monkshood)

I-2 Larkspur

$\mathrm{J}-3$ Phlox-in variety

SUGGESTION No. 2

A-1 Yucca

B-2 Achillea

C-3 Golden Glow

D-4 Gaillardia (Blanket Flower)

E-3 Larkspur

F-4 German Iris-in variety

$\mathrm{G}-4$ Anemone

H-4 Foxglove

I-2 Aconitum (Monkshood)

J-3 Coreopsis

Japan Iris-in variety
A Center Entrance 20 feet long for each side of the walk.

A Cosy Corner Planting Plan, L Shape

By combining either one or two of these plans, adaptable for front or rear garden.

A Long Perennial Bed By combining the two plans suitable for a border planting paralleling the driveway or the property line.
PLANTING SUGGESTIONS FOR PLAN No. 33
A-6 Pinks (Dianthus)

C-4 German Iris-Purple

F-6 Larkspur

G-4 Veronica

$\mathrm{K}-3$ Garnation
B-6 Arabis

D-6 Candytuft

E-3 Achillea

I-7 Sweet William

J-4 German Iris-Yellow
L-6 Blanket Flower

M-3 German Iris-Lavender

$\mathrm{N}-6$ Dwarf Phlox

$\mathrm{O}-3$ Coreopsis

p-6 Coreopsis

P-4 Japan Iris-Pink

$\mathrm{Q}-4$ Japan I

-6 Alyssum

S-6 Primrose

T-3 German Iris-Blue
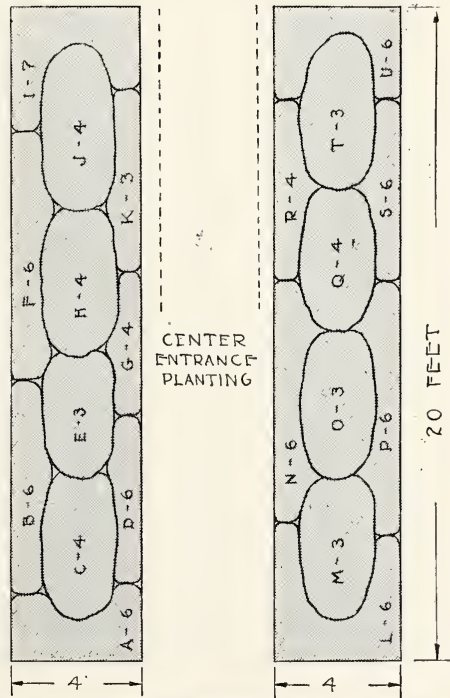

REAR YARD PLANTING

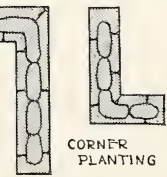




\section{CLASSIFIED SHRUBS—Adapted to City Lot-SPECIAL USES}

The succeeding lists of shrubs and vines are in no sense complete under the various headings, but denote the types and varieties most generally known and used for certain special requirements of the average lot. Planting intervals of shrubs can be varied to meet individual requirements.

\section{SHRUBS FOR FOUNDATION PLANTING}

I. Sunny Exposure

A HIGH.GROWING:

Deutzias-Crenata, etc.

Exochorda Grandiflora

Bush Honeysuckles-in variety

Common Lilacs

Philadelphus-in variety

Lantana (Viburnum)

Lantago (Viburnum)

Tomentosum (Viburnum)

Weigelas-Candida floribunda

Colutea (Bladder Senna)

Daphne (Cneorum)

Ruprechtiana

Spirea-Douglassi

Syringa-Grandiflora

Tamarix-African, etc.

B MEDIUM HEIGHT:

Cornus Elegantissima Variegated

Hydrangeas-A. G., and P. G.

Honeysuckle Morrowii

Philadelphus Aureus,

Privet-Ibota, Regel's

Spireas-Prunifolia, Van Houttei,

Symphoricarpus-Indian Currant,

Weigelas-Rosea Amabilis, Variegated-lf.

Flowering Raspberry

Honeysuckle (Bella Albida)

\begin{tabular}{llll}
\multicolumn{3}{c}{ Planting } & \\
interval & Page \\
4 & -5 & ft. & 16 \\
4 & -5 & ft. & 18 \\
4 & -5 & ft. & 17 \\
4 & -5 & ft. & 18 \\
4 & -5 & ft. & 20 \\
4 & -5 & ft. & 19 \\
4 & -5 & ft. & 19 \\
4 & -5 & ft. & 19 \\
4 & -5 & ft. & 21 \\
4 & -5 & ft. & 15 \\
8 & -24 & in. & 15 \\
4 & -5 & ft. & 17 \\
3 & -4 & ft. & 20 \\
4 & -5 & ft. & 20 \\
4 & -5 & ft. & 20 \\
& & & \\
3 & -4 & ft. & 16 \\
3 & -4 & ft. & $17-18$ \\
4 & -5 & ft. & 17 \\
3 & -4 & ft. & 20 \\
3 & -4 & ft. & 26 \\
3 & -4 & ft. & 20 \\
3 & -4 & ft. & 19 \\
3 & -4 & ft. & 21 \\
3 & -5 & ft. & 16 \\
4 & -5 & ft. & 17
\end{tabular}

C LOW-GROWING:

Barberry, Thunberg's

Callicarpa Purpurea

Deutzias-Gracilis and Lemoinei

Kerria Japonica fl. pl.

Baby Rambler Roses-in variety

Spireas-A. Waterer, Callosa Alba

Weigela- Thunbergii, etc.

Potentilla Fruticosa

Spirea-Bumalda

Spirea-Froebeli

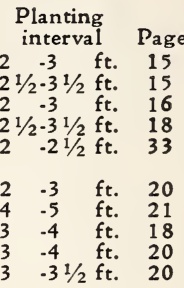

II. Shady Exposure

A HIGH GROWING:

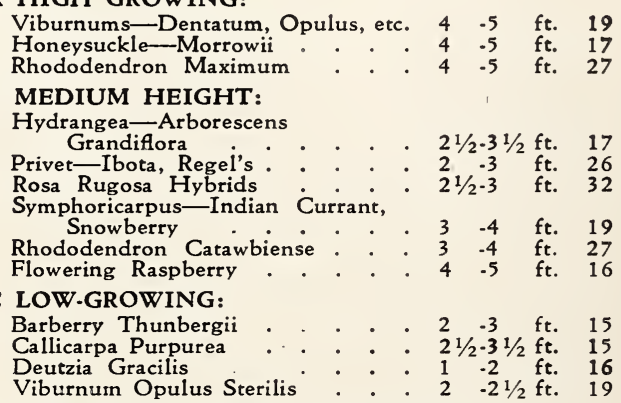

\section{SHRUBS FOR BACK-YARD OR BORDER PLANTING}

\section{Sunny Exposure}

A HIGH GROWING:

All shrubs in Group I-A.

$\begin{array}{ccc}\begin{array}{c}\text { Planting } \\ \text { interval }\end{array} & \text { Page } \\ 1 / 2-41 / 2 & \mathrm{ft} . & 15 \\ 1 / 2-41 / 2 & \mathrm{ft} . & 16 \\ -5 & \mathrm{ft} . & 16 \\ -5 & \mathrm{ft} . & 16 \\ -5 & \mathrm{ft} . & 16 \\ -5 & \mathrm{ft} & 18 \\ -4 & \mathrm{ft} & 20 \\ -5 & \mathrm{ft} . & 20\end{array}$

C LOW.GROWING:

All plants in I.C.

Clethra Alnifolia

Forsythia Suspensa

interval Page

All the dwarf Spireas

$21 / 2-31 / 2 \mathrm{ft} . \quad 15$ $21 / 2 \cdot 31 / 2 \mathrm{ft}$. $\quad 16$

Shady Exposure

A HIGH-GROWING:

All plants in II-A.

Cornus-in variety . . . . . . $\begin{array}{llll}3 & -5 & \mathrm{ft} . & 16\end{array}$

Bush Honeysuckles-in variety. $\begin{array}{llll}4 & -5 & \mathrm{ft} . & 17\end{array}$

Viburnums-in variety

$B$ MEDIUM-HEIGHT:
All plants in II-B.

C LOW-GROWING:

All plants in II.C.

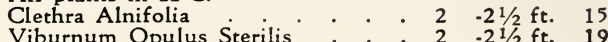

Buddleia Magnifica (Butterfly Bush) $3{ }^{-4}$ ft. 15

Deutzias-Lemoinei, etc. $2 \frac{1 / 2-3}{\mathrm{ft} .} 16$

\section{CLIMBING AND GROUND-COVERING VINES AND SHRUBS}

For Ground-Covering

\begin{tabular}{|c|c|c|c|c|c|c|}
\hline BANKS AND & & 10 & & & & Page \\
\hline $\begin{array}{l}\text { Indian Currant } \\
\text { Barberry, Thunberg's : } \\
\text { Forsythia Suspensa } \\
\text { Flowering Raspberry : }\end{array}$ & $::$ & $::$ & $\begin{array}{l}21 / 2 \\
21 / 2 \\
3 \\
4\end{array}$ & $\begin{array}{r}2-3 \\
2-3 \\
2-3 \\
.4 \\
.5\end{array}$ & $\begin{array}{l}\text { ft. } \\
\text { ft. } \\
\text { ft. } \\
\text { ft. }\end{array}$ & $\begin{array}{l}19 \\
15 \\
16 \\
16\end{array}$ \\
\hline ANKS AND & ERR & RACES: & & & & \\
\hline $\begin{array}{l}\text { Ampelopsis } \\
\text { Bittersweet } \\
\text { Honeysuckles-Halleana, } \\
\text { Matrimony Vine } \\
\text { Rosa-Wichuriana type } \\
\text { All in group A (above). }\end{array}$ & : etc. & $::$ & $\begin{array}{l}4 \\
4 \\
4 \\
5 \\
4\end{array}$ & $\begin{array}{l}-5 \\
-5 \\
-5 \\
-6 \\
-5\end{array}$ & $\begin{array}{l}\text { ft. } \\
\text { ft. } \\
\text { ft. } \\
\text { ft. } \\
\text { ft. }\end{array}$ & $\begin{array}{l}22 \\
21 \\
22 \\
22 \\
34\end{array}$ \\
\hline
\end{tabular}

\section{For Climbing}

On porch, trellis, fence or wall. Those types which cling to wood, stone, brick or stucco-are designated by a star $(*)$; the rest twine or need support.

*Ampelopsis-in variety (Veitchii,

*Bignonia Radicans (Trumpet Vine) 6 - 6 ft. 22

Evergreen Bittersweet $: 0.10 \mathrm{ft} .21$

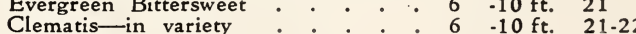

Dutchman's Pipe (Aristolochia

Dutchman's Pipe (Aristolochia
Sipho)

Honeysuckles - in variety : : 8 - $10 \mathrm{ft} .22$

$\begin{array}{lllll}\text { Climbing Roses - in extensive variety } & 6 & -8 & 8 \mathrm{ft} . & 33-34 \\ \text { Wistarias-in variety . } & 0 & -10 \mathrm{ft} . & 22\end{array}$

\section{HEDGES: SHRUBS MOST COMMONLY USED}

Informal Lines-Not Clipped

Barberry, Thunberg's

Privets-in variety

Altheas-in variety

Indian Currant

Mock Orange-in variety

Dwarf Spireas -in variety

Spirea Van Houttei

Japan Quince
Planting

interval Page

$1-11 / 2 \mathrm{ft} . \quad 15$

8 - 12 in. 26

2 - $21 / 2 \mathrm{ft} . \quad 19$

$21 / 2 \mathrm{ft} . \quad 20$

$11 \frac{1}{2} \mathrm{ft} . \quad 20$

$\begin{array}{lll}11 / 2-2 & \mathrm{ft} . & 20 \\ 1 & -11 / 2 \mathrm{ft} . & 19\end{array}$

\section{Clipped-Formal Design}

Barberry, Thunberg's California Privet

Amoor River Privet

Regel's Priver

Lodense Privet

and various Evergreen types are used with fine effect, but these greatly increase the expense of first cost, and maintenance. 


\section{Hardy Flowering Shrubs}

$\mathrm{T}$ HOSE who desire flowers about their home lawn and garden during the summerblooming from April to October-may select from the following list. The varieties flower in the order named.

APRIL-Daphne-Cneorum.

May-Forsythia in variety, Japan Quince, Prunus Pissardi, Prunus triloba, Almond, Spirea prunifolia flore pleno, Lilacs, Spirea Van Houttei, Viburnum lantana, Bush Honey. suckle, Wistaria.

JUNE-Deutzia gracilis, Deutzia Lemoineii, Spirea lanceolata, Viburnum opulus, Weigela, Cornus alba, Lilac Japonica, Hydrangea arborescens grandiflora alba, Syringa, Rhododendrons, Paeonies Herbaceous, Clematis Jackmanni, Elder, Deutzia, Pride of Rochester.

JULY-Spirea Billardii, Spirea Anthony Waterer, Amorpha, False Indigo.

AUGUST AND SEPTEMBER-Althea, Hydrangea paniculata grandiflora, Clematis paniculata.

For the shady places: Barberry, Ceanothus, Cornus, Deutzia, Forsythia, Honeysuckle, Kalmia, Myrtle, Privet, Rhododendron, Rhus, the Viburnums, Yew.

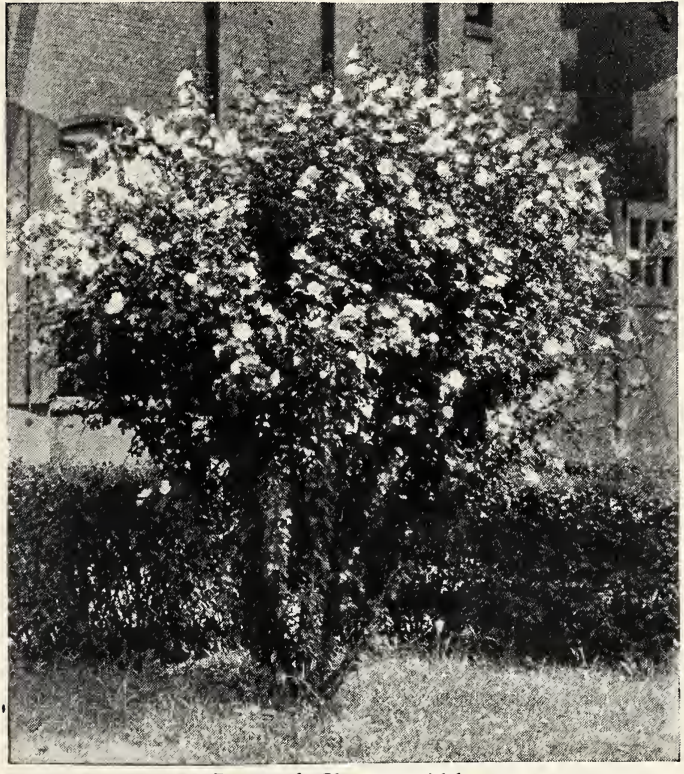

Rose of Sharon-Althea

ALMOND (Amygdalus)-The flowers are very showy, produced in great abundance and useful for their earliness. Fine plants to use in grouping or for lawns.

Double Pink-Small, double pink flowers borne in abundance in May.

Double White-Small, double white flowers borne in abundance in May.

ALTHEA (or Rose of Sharon or Hibiscus)-The altheas are free growers and not particular as to soil. Large, bell-shaped flowers of striking colors in August and September, when but few other sorts are in blossom. They attain a height of from six to ten feet.

Double Purple, Double Red, Double Pink, Double White-Very large and double, with reddishpurple center.
TREE ALTHEAS-Flowers are the same as bush form. Grown on a single stem instead of being branched from ground as bush form.

AMORPHA (Lead Plant)-Low-growing, dense, with silvery foliage. Bears heavy clusters of light blue flowers in June. Fine for rock gardens, growing only two or three feet high.

BUDDLEIA (Everblooming Butterfly Bush) - This shrub, set out in spring, will mature to full size the first year. A single plant will show, the first season, as many as fifty flower spikes of beautiful lilac color. Both foliage and blooms very attractive. Desirable for specimen planting. (IIlustrated on page 16.)

BARBERRY (Thunberg's) - From Japan. A pretty species of dwarf habit and small foliage changing to a beautiful coppery red in autumn. Valuable as an ornamental hedge.

CALYCANTHUS (Sweet Scented Shrub)-Very desirable. Wood is fragrant, foliage rich, flowers of a chocolate color having an agreeable odor. They blossom in June and at intervals afterward.

CALLICARPA PURPUREA (Beauty Fruit)-This splendid shrub has dark green leaves 2 to 3 inches long. The flowers are pink, produced about mid-summer, and are followed by violet. purple fruit. It is quite distinct and very ornamental.

CLETHRA ALNIfOLIA (Sweet Pepper Bush)A pretty little shrub that blooms freely for several weeks in summer; very fragrant, white flowers.

COLUTEA (Bladder Senna) Arborescens. C.-A large shrub, with small, delicate foliage, and yellow, pea-blossom-shaped flowers in June, followed by reddish pods or bladders. 2 to 3 feet.

DAPHNE-CNEORUM (Garland Flower)-Handsome, dwarf, evergreen shrub, growing 15 to 18 inches in height, excellent for foreground planting in the shrub border. Fragrant pink flowers and glossy green foliage. 


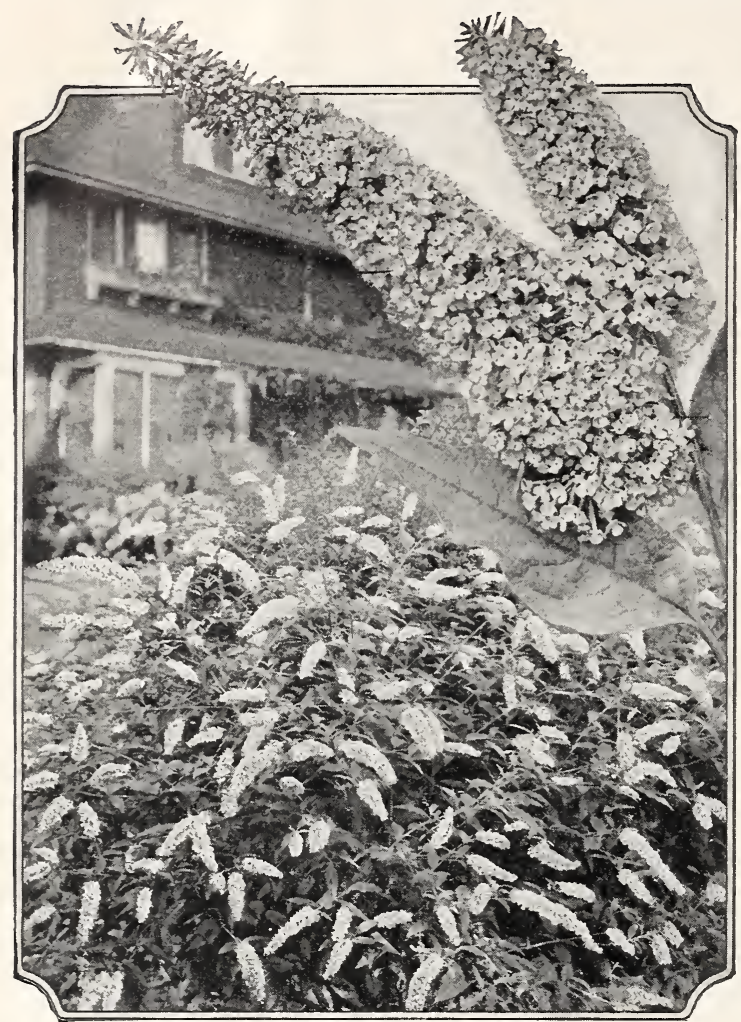

Butterfy Bush

A Beautiful Summer Lilac

\section{DEUTZIA}

Showy Japanese shrubs of the highest ornamental merit, and adapted to all good soils.

Their clean foliage, upright dense growth, free-flowering nature, render them especially valuable.

CRENATA-The beautiful, white, single-flowered species that is a mass of bloom in June.

GRACILIS (Dwarf)-Slender, branched variety, dwarf habit and very early flowering. Flowers pure white. Blooms in June.

LEMOINE-Flowers pure white, borne in profusion on stout branches which are of upright growth. Habit dwarf and free-flowering. Blooms in June.

PRIDE OF ROCHESTER-Produces large, double white flowers in June. The best of the Deutzias; very vigorous growth; profuse bloomer.

See colored illustration in front.

\section{DOGWOOD-Cornus}

CORNUS ELEGANTISSIMA (Variegated)-One of the finest variegated shrubs; of rapid growth, the leaves are broadly margined with white, while some are entirely white.

CORNUS SANGUINEA (Red Branched)-Very conspicuous and ornamental, especially in winter when the bark turns to a blood-red.

Refer to Ornamental Trees for larger growing varieties.
ELDER (Elderberry)-Sambucus

COMMON ELDER-Broad panicles of white flowers in June; reddish purple berries in autumn. Fruit fine for pies and makes an excellent drink.

CUT-LEAVED ELDER-One of the best cutleaved shrubs. Blooms in June.

GOLDEN ELDER-Leaves bright green when they first appear, but if planted where they will get the sun, they change to a golden green. Best effect is had when planted with other shrubs, when the foliage will appear more conspicuous. June.

\section{ELEAGNUS-Oleaster}

E. LONGIPES (Japan Oleaster) - In July the plant is covered with red berries. The bush is highly ornamental, the leaves remaining fresh till late autumn.

\section{EUONYMUS-Strawberry or Spindle Tree}

AMERICAN BURNING BUSH-Very conspicuous in the autumn and winter when loaded with scarlet seedpods, from which the orange-colored berries hang on slender threads.

EUROPEAN BURNING BUSH-From Europe, and a favorite in old gardens; of good size, with rosy-red pods.

\section{EXOCHORDA-Pearl Bush}

GRANDIFLORA-One of the most distinctly ornamental shrubs in cultivation, a leader in its season. It grows vigorously to a height of 6 to 10 feet, and can be trimmed to any desirable shape. Stands our severe winters well. Has never failed to bloom yet. The early buds look like pearls strung on slender threads; May opening them up to long, gleaming sprays of pure white. One of the best.

\section{FILBERT-Hazel-nut}

ENGLISH-Makes a 10 to 12 foot tree in time; useful for its fine "Hazel" nuts in fall.

\section{FLOWERING RASPBERRY}

Of bushy growth, growing 4 to 5 feet high, with fine, large leaves and clusters of beautiful pink and purple fragrant flowers all summer.

\section{FORSYTHIA-Golden Bell}

These splendid shrubs, growing 8 to 15 feet tall, eventually light up the garden with glinting masses of yellow very early in spring before the leaves appear. Their bright golden flowers, often appearing before the snow is gone, vie with the Crocus as harbingers of spring.

INTERMEDIA-The earliest blooming.

VIRIDISSIMA-Resembles the Fortunei in height and blossom, but is more compact, with darker leaves and branches.

SUSPENSA-Very long, curving branches, giving a weeping appearance; ultimate height of the variety about 4 feet.

FORTUNEI - Growth upright; foliage deep green; flowers bright yellow, appearing before the leaves. Very showy.

See colored illustration in front. 


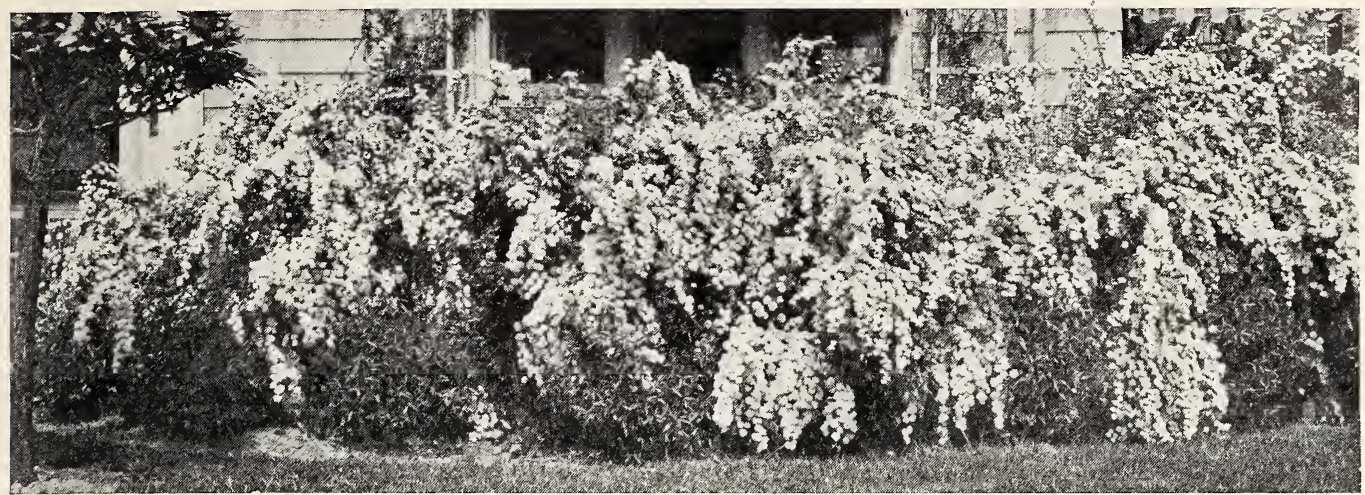

A Foundation Planting Showing Spirea Van Houttei

\section{FRINGE TREE}

PURPLE (SMOKE TREE) (Rhus Cotinus)-A conspicuous spreading shrub or small tree, with large, clusterly round leaves; overhung in midsummer by mist-like clouds of tiny flowers. These billowing panicles are a light lavender when fresh, very persistent, and give the impression of smoke at a distance.

WHITE (Chionanthus) - A very desirable tall growing shrub; foliage dark green, turning yellow in autumn. Flowers pure white, in loose, drooping panicles, appear in May and June fol. lowed by small, plum-like berries of bluish color.

\section{HONEYSUCKLE-Bush}

BELLA ALBIDA-A strong, rapid growing shrub. White flowers in May and scarlet berries in mid-summer. Fine shrub for high foundation plantings or shrub borders.

FRAGRANTISSIMA (Upright)-Foliage bright green, almost an Evergreen. A large, spreading shrub with sweet, creamy white flowers. Blooms in April to May.

LONICERA MORROWII-A species from Japan. It is a strong, upright grower. Creamy white flowers followed by deep red berries, which ornament the bush until autumn. Blooms in May and June.

PINK TARTARIAN (Upright Lonicera Tartarica)-The best known of all the Bush Honey- suckles, and in our estimation the finest variety of all. Grows to a height of 8 to $10 \mathrm{feet}$, with upright, somewhat spreading branches and bright green foliage. The flowers are borne freely in May and June, are of bright pink color, followed by showy red berries, which ripen in mid-summer, and cling to the bush for several weeks. One of the shrubs for Northern latitudes as it withstands the severest winters. Blooms in May and June.

RUPRECHTIANA - A vigorous, upright shrub, growing 7 to 8 feet high. White flowers appear in May and June followed by bright red fruit in autumn. Fine for masses and screen effects.

WHITE TARTARIAN (Upright) - About the same as the above except that the flowers are white.

\section{HYDRANGEA}

HYDRANGEA ARBORESCENS, Hills of Snow or Everblooming-Becomes a good-sized shrub to which the name Hills of Snow may well be applied-a profusion of large, snow-white flow. ers turning green instead of bronze as do other hydrangeas. Easily grown in ordinary garden soil and thrives in partial shade, but does best in full sun. It blooms from June till August, when the Paniculata begins. Strong, field-grown plants.

See colored illustration in front.

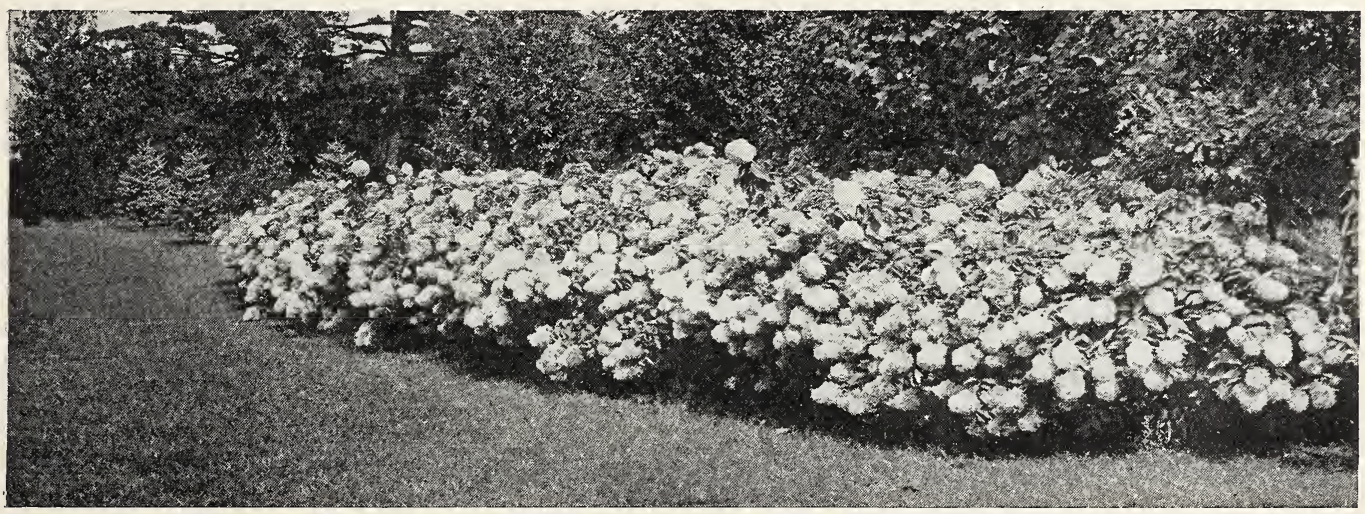

Luxuriant Bloom of Massed Hydrangeas with Leafy Background 


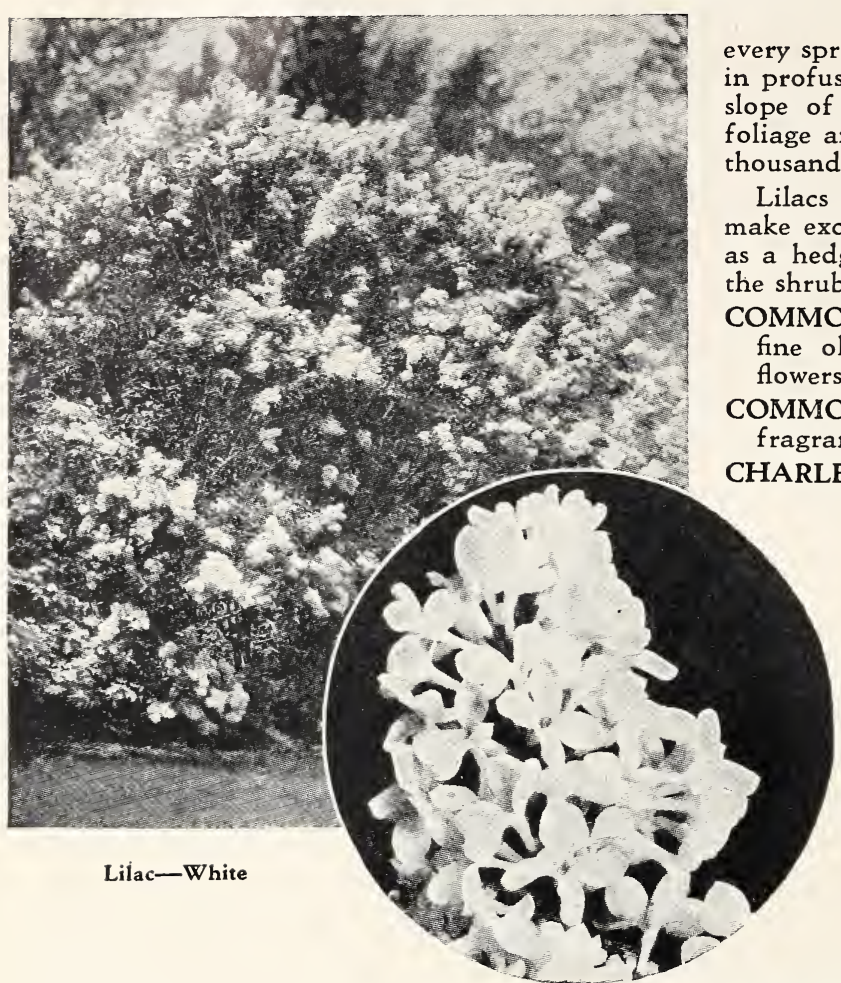

every spring at Highland Park, Rochester. Planted in profusion along the paths of the shrub covered slope of this natural park, the heavy masses of foliage and wealth of blooms bring visitors by the ands for miles around.

acs usually attain a height of 6 to 8 feet and ake excellent screens for unsightly fences as well shrubbery border.

ON PURPLE-The familiar species of all fine old gardens, with dense panicles of lilac flowers, and the most fragrant of them all.

OMMON WHITE-Pure white in color, very fragrant flowers.

CHARLES X-Reddish purple.

FRAU DAMMANN-This is the best white lilac grown. The panicle or truss is immense, flowers of medium size and pure white. This and Ludwig Spaeth are the two best lilacs of recent introduction.

LUDWIG SPAETH-New, and believed to be the finest of its class. Color purplish-red. A great acquisition.

MARIE LE GRAYE-A free grower, producing magnificent large trusses of purest white flowers, which are very fragrant and showy. Highly recommended as perhaps the best of the white lilacs.

HYDRANGEA P A N I C U L A T A GRANDIFLORA - A good variety to follow Hills of Snow, blooming profusely in August and September when few other shrubs are in bloom. It produces the largest flower heads of any of the hardy shrubs. Allowed to grow naturally it assumes stately proportions, reaching a height of seven feet, and during the hot months is covered with its green pyramidal panicles, white on opening, assuming rose and bronze tints on the sunny side and drooping gracefully of their own weight.

See colored illustration in front.

HYDRANGEA PANICULATA in Tree FormIt is very effective for the lawn or park, or planted along the sidewalks or driveways, about 10 feet apart; it makes a most beautiful sight when in full bloom. Is particularly effective when planted in pairs, one on either side of a formal entrance. Blooms in August and September.

\section{KERRIA-Corchorus Globe Flower}

JAPONICA (Japan Corchorus) - A handsome green-leaved shrub, growing 3 to 5 feet. Graceful, slender, drooping branches, painted with a wealth of rich, dark yellow flowers in June, and to some extent, all summer.

FLORE PLENO (Double-Flowered Corchorus)Of medium size; double yellow flowers.

\section{LILAC}

Lilacs are always popular and thrive almost anywhere. With very little care they can be depended upon each May for a profusion of delightfully fragrant, colorful blooms, flowering long before many other varieties of shrubs.

Probably the finest collection of lilacs to be found anywhere forms the center of attraction

MADAME LEMOINE-New and very promising. Flower double white.

PERSIAN, PURPLE-Foliage resembles the Privet more than the lilac. Flowers are most abundant.

Write for additional list of named varieties.

\section{POTENTILLA FRUTICOSA}

A low growing shrub, not over 3 feet high, with bright yellow flowers through the summer and dense narrow gray-green foliage. Fine for moist places, rockeries and shrub borders.

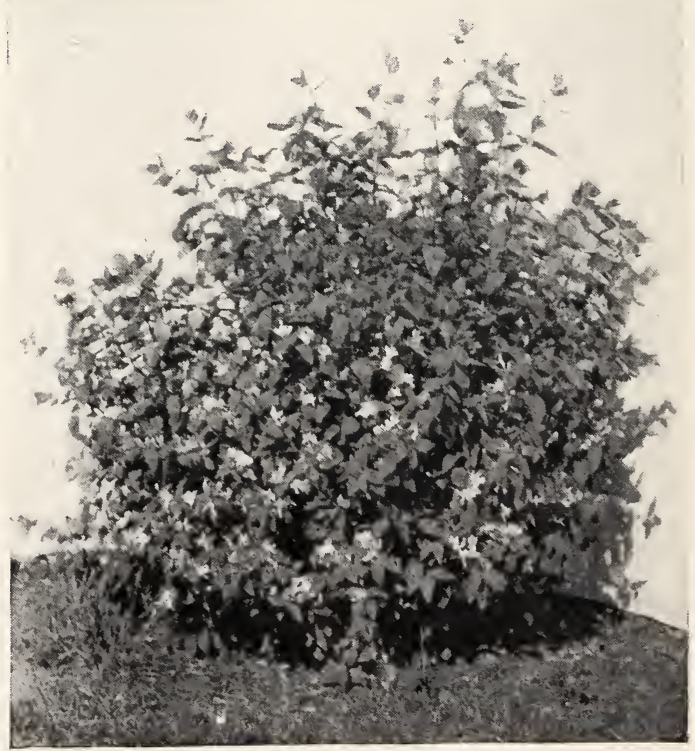

Honeysuckle Tartarian 


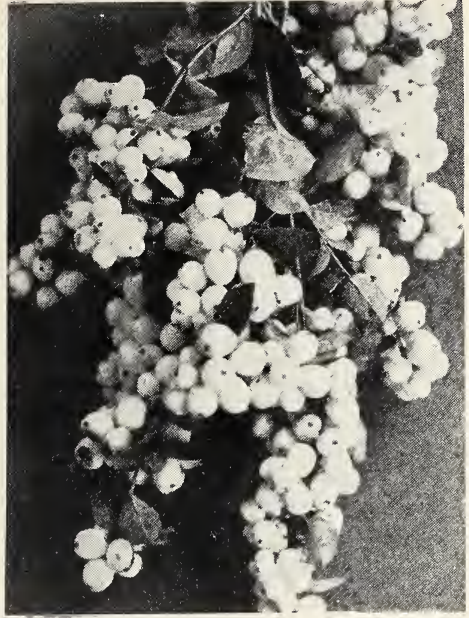

Snowberry, White

\section{PLUM-Prunus}

PURPle Leaved PlUM, Prunus PissardiA purple leaved small tree of recent introduction. The young branches are a very dark purple. Leaves when young are a lustrous crim. son, changing to dark purple, and retain this beautiful tint until they drop late in the autumn; no other purple-leaved tree or shrub retains its color like this. Flowers, small, white, single, covering the tree. May.

TRILOBA (Double-Flowered Plum)-A charming shrub of vigorous growth. Very early in spring, before its leaves appear, the whole tree is decked in a fleecy cloud of very double, light-pink blossoms. Its effect on a still, leafless landscape is very bright. Blooms in May.

\section{PRIVET}

IBOTA-See Hedges, page 26.

REGEL'S-See Hedges, page 26.

\section{QUINCE-Pyrus Japonica}

JAPONICA-Very ornamental in early spring, as its bright, scarlet flowers completely cover the branches before the leaves are formed. Makes a good hedge. Blooms in early May.

\section{SNOWBALL-Viburnum}

DENTATUM-Has glossy green foliage, white flowers in June; crimson berries turning blue in autumn. One of the best shrubs for landscape planting.

LANTANA-Upright shrub growing 10 to 12 feet high with rough, light green foliage. Large heads of white flowers in June, followed by bright red fruit.

LANTAGO - Tall growing shrub with glossy green leaves. Fragrant white flowers in June and blue-black fruit in autumn.
PLICATUM (Japan Snowball) -A rare and exceedingly beautiful species of Japan; flowers in large, globular heads; pure white, hanging long on the bush; a very choice and desirable shrub. Blooms in May.

OPULUS (Cranberry, High Bush)-A very decorative native shrub, growing 8 to 10 feet high, with white flowers in May followed by beautiful, showy clusters of scarlet fruits.

TREE FORM SNOWBALL-These are very attractive and different from the average shrub. Have been carefully grown and have large, well developed tops. Blossoms May and June.

OPULUS STERILIS (Common Snowball) Grows 6 to 8 feet high, the old-fashioned Snowball; its large, globular clusters of pure white flowers are produced in May and June, and make a very attractive appearance.

TOMENTOSUM-A most beautiful and useful shrub used as a specimen or in the shrubbery border. Grows 8 to 12 feet high. White flowers appearing in June.

\section{SNÓWBERRY—Symphoricarpus}

RACEMOSUS (White)-Small, rose-colored flowers in June and July, followed by large clustered, milk-white fruits, which remain far into winter. The combination of pink flowers and white berries on the same twig is charming. July to October.

VULGARIS (Red) Indian Currant-A low-growing, graceful shrub. Its fruits are red, and the smaller red berries cluster in thick ropes along the weighted down stems. August.

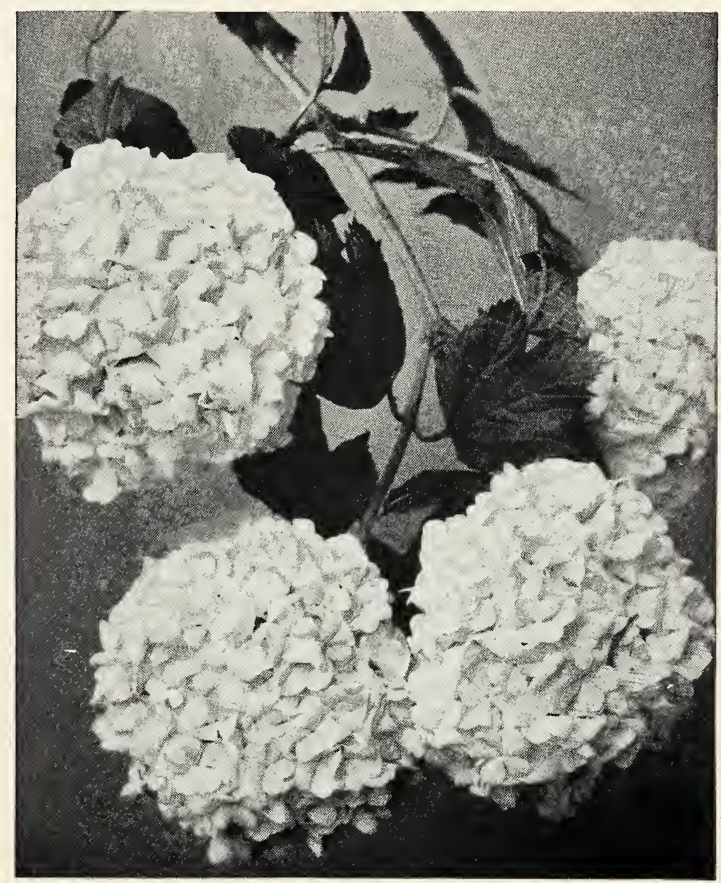

Common Snowball-Viburnum opulus sterile 


\section{SPIREA-Meadow Sweet}

Few shrubs lend themselves to every situation or condition as well as Spireas; showy, free flowering shrubs of easiest culture and covering a considerable blooming period from spring to summer. They are valuable for garden, lawn and landscape planting, being graceful, compact and hardy, preferring sunny situations.

ANTHONY WATERER-A new dwarf, compactgrowing shrub. Blossoms in broad flat heads of beautiful deep red color. A perpetual bloomer. July and August.

See colored plate in front.

ARGUTA or Garland-One of the finest of early spring blooming shrubs; of light, open habit of growth, with small, deep green foliage; of minute, purest white flowers. Early May.

AUREA (Golden) - The leaves are bordered with golden-yellow, particularly in June, when the branches are covered with small, double, white flowers.

BILLARDII-Blooms nearly all summer; rosecolored; fine, showy. July to September.

BUMALDA (Bumalds Spirea)-A dwarf, bushy plant rarely growing more than 3 feet in height, with large, flat heads of rosy-pink flowers from July until October. A good shrub for the low border.

CALLOSA ALBA-A white flowering variety of dwarf habit. Remains in flower all summer.

CALLOSA RUBRA-Desirable because it blooms nearly all summer. The flowers are rose-colored, borne in panicles. A very free grower. June and July.

DOUGLASI - Taller than Billardii in growth. Deep pink flowers in July. Excellent plant for tall shrub borders and dry places.

FROEBELI-A taller form than Anthony Waterer, growing 3 to 4 feet high, with broader leaves and bright crimson flowers over a long period.

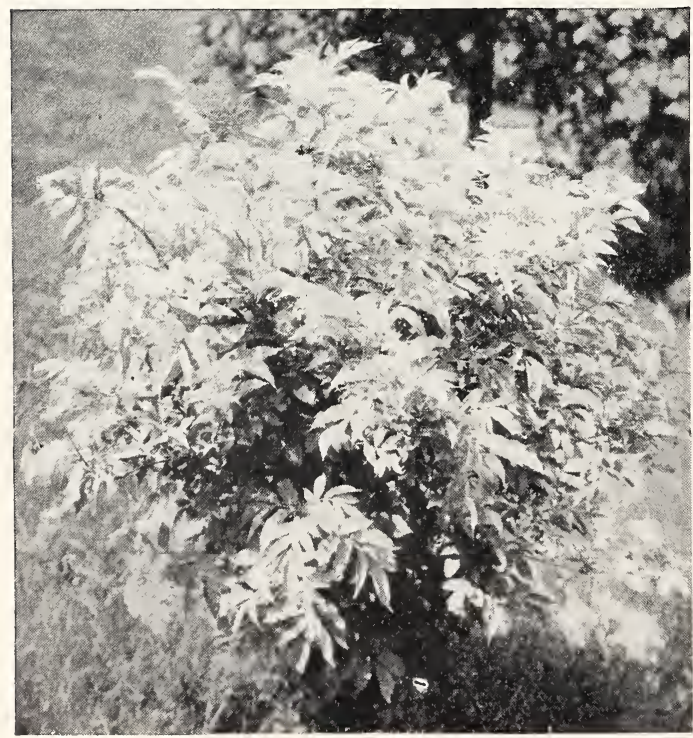

Golden Elder
PRUNIFOLIA (Bridal Wreath)-Beautiful white flowers, double and very profuse. Blooms in May. Foliage, scarlet in autumn.

REEVESII - A charming shrub, with narrow, pointed leaves, and large round clusters of white flowers that cover the whole plant. July and August.

THUNBERG'S (Thunbergii) - A Japanese species of small size, with narrow, linear leaves and small, white flowers; one of the best. Early May. Branches slender and somewhat drooping. First Spirea to bloom.

VAN HOUTTEI-The finest of all Spireas, a most charming and beautiful shrub; having pure white flowers in clusters. Extraordinarily profuse in bloom, and the plant is a vigorous grower and very hardy. May and June.

\section{SUMAC-Rhus}

CUT-LEAVED SUMACH-A very striking plant, of moderate size, with deeply cut leaves, resembling fern leaves; dark green above and glaucous below, and turning to a rich red in autumn.

STAGHORN SUMACH-A large shrub or tree, brilliant foliage and scarlet fruit in autumn.

\section{SYRINGA OR MOCK ORANGE- Philadelphus}

For grouping with other shrubs, forming large screens or hedges which may not require pruning, or used as single specimen lawn plants, they are desirable. They will bear heavy pruning and quickly resume their free, semi-pendulous, picturesque effect.

CORONARIUS-Early June. Fragrant, pure white flowers in dense clusters, so numerous as to bear the branches down when flowering. One of the best. May and June.

See colored plate in front.

AUREUS (Golden Syringa) - A dense growing form, with clear, golden-yellow foliage well retained in color all summer. One of the best golden-foliaged shrubs offered.

VIRGINAL-One of the most beautiful new varieties. A vigorous, tall grower, with very large, double-crested flowers, with round petals. Pure white, sweetly scented clusters of five to seven blossoms. May and June.

GRANDIFLORA-A vigorous variety, with large, creamy-white flowers in June. Upright in growth with good foliage. It merits a place in every shrub border.

\section{TAMARIX}

AFRICAN (Africana)-Thrives in any soil. The foliage is handsome. The flowers are small, borne in spikes in May. Its habits are upright.

CHINENSIS-A vigorous, upright grower; delicate light green foliage; flowers rose-colored in September. 


\section{WEIGELA-Diervilla}

Beautiful shrubs that bloom in June and July. The flowers are produced in so great profusion as almost entirely to hide the foliage. They are very desirable for the border or for grouping, and also as specimen plants for the lawn.

AMABILIS-Of robust habit, large foliage and pink flowers; blooms freely in the autumn; distinct and beautiful.

CANDIDA - Of vigorous habit; flowers pure white and produced in great profusion in June, and continues to bloom at intervals through the summer.

EVA RATHKE-A charming, new Weigela; flowers, brilliant crimson; a beautiful, distinct, clear shade; mid-summer.

FLORIBUNDA-Beautiful, dark crimson flowers. Profuse bloomer in June.

VARIEGATED-An exceedingly pretty variety, the variegation being very distinct. Of dwarf habit; finely variegated foliage which lasts the entire season. Flowers rose-colored. Leaves bordered with yellowish-white. June.

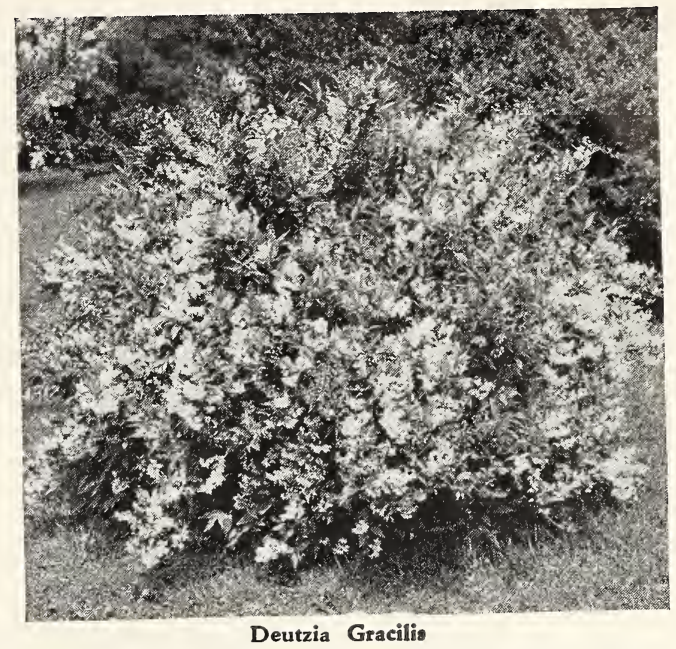

ROSEA-Has beautiful, rose-colored flowers. Dis. tinctive; very hardy. Blooms in June.

See colored illustration in front.

\section{Hardy Climbing Vines}

$\mathrm{V}$ INES always add grace and beauty. Some are prized for the color and fragrance of their flowers, while others are valuable for covering brick or stone walls. Vines rank as the most beautiful plants for training on fences, on old trees, over porches and windows. In spring and summer their foliage is a mat of green leaves, and turns to rich yellow, gold and bronze in autumn.

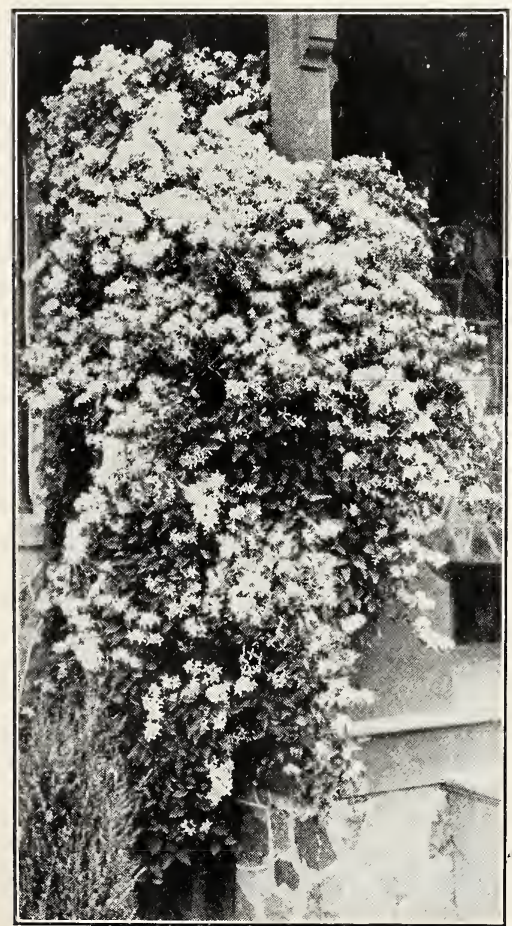

Clematis Paniculata

\section{EVERGREEN BITTERSWEET}

EUONYMUS VEGETUS-A vine that is beautifully green the year 'round. Will thrive most anywhere, but the fruiting is best when exposed to the sun. Strong, robust climbers that bear a profusion of orange-red berries in fall and winter.

\section{CINNAMON VINE}

A strong, hardy climber from China. 10 to 30 feet. Leaves heart-shaped; flowers small, white, cinnamon-scented. Very fragrant. Impervious to insects and blight. One of the best.

\section{CLEMATIS}

This is one of the most attractive and effective of the hardy flowering climbing vines. Especially adaptable for covering trellises, fences, walls and pillars, also suitable as a bedding plant, covering a bed quickly if fastened down occasionally.

COCCINEA-A bright, scarlet color, heavy petaled flower, bell shaped. In bloom over a wide season from July to October.

DUCHESS OF EDINBURGH-One of the double, pure white varieties; deliciously scented. July to September.

HENRYII-Flowers large and creamy white, from six to eight petals. Fine bloomer from July to October.

JACKMANI-Covered from July to October with a dense foliage of purple flowers. A strong grower and popular variety.

MADAME EDW. ANDRE-Flowers bright, velvety red. Larger and continuous bloomer. July to September. 
PANICULATA-Flowers are medium in size, but exceptionally fragrant, with fine foliage in late summer.

RAMONA-This magnificent new Clematis is an American seedling, and consequently extremely hardy. The Ramona is a strong, rampant grower, fully three times as strong as the Jackmani, of ten growing ten or twelve feet the first season. It is a perpetual bloomer, giving an abundance of flowers through the season. In color it is a very deep sky-blue.

\section{DUTCHMAN'S PIPE-Aristolochia}

A native species of climbing habit and rapid growth, with magnificent light green foliage, 10 to 12 inches in diameter, and curious pipe-shaped, yellowish-brown flowers.

\section{HONEYSUCKLES}

HALL'S JAPAN HONEYSUCKLE-A strong, vigorous, almost evergreen sort, with pure white flowers, changing to yellow. Covered with fragrant flowers from July to December. Holds its leaves till January. The best bloomer of all.

MONTHLY, FRAGRANT OR DUTCH HONEYSUCKLE-Blooms all summer; red and yellow. Very fragrant flowers.

SCARLET T R UM P E T HONEYSUCKLEStrong, rapid grower. Produces scarlet inodorous flowers. June to September.

\section{IVY-Ampelopsis}

AMERICAN IVY, WOODBINE OR VIRGINIA CREEPER-A very desirable vine for covering walls, verandas, and tree trunks. Leaves are beautiful in summer, turning a rich crimson in autumn. A fast grower.

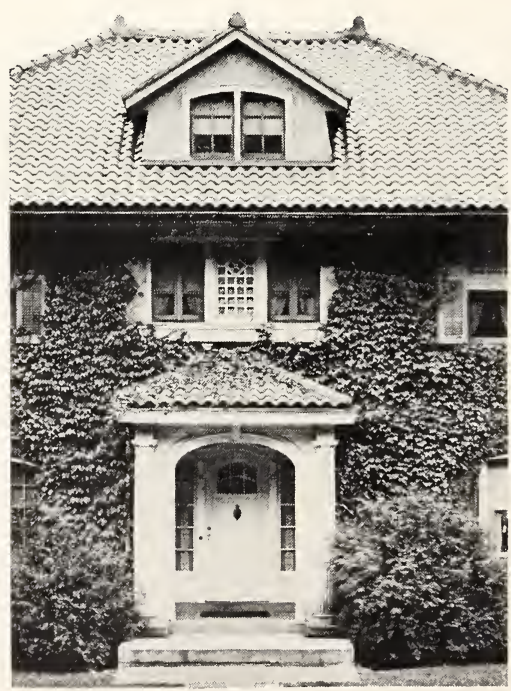

Ampelopsis Veitchi (Boston Ivy)

This Foliage is Restful-Increasing the Charm and Value of Your Property

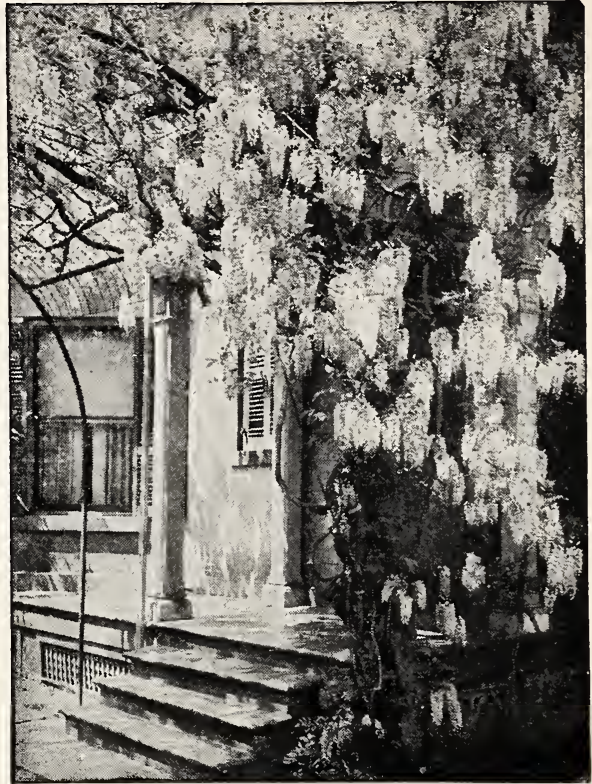

Wistaria (Purple)

BOSTON IVY (Japan)-A tight climber; among the best as a basket or vase plant. Leaves attain a brilliant crimson in autumn. Hardy. Japanese in origin.

ENGELMANNI-Similar to Quinquefolia. A good climber, growing from six to ten feet in a season.

ENGLISH IVY - Used extensively for covering brick and stone walls. A good small leaved variety but not very hardy north of Philadelphia.

\section{MATRIMONY VINE}

A vigorous climber, branching freely and covered with brightly purple, star-shaped flowers, succeeded by brilliant scarlet berries. Fine for porches.

\section{TRUMPET VINE-Bignonia}

Flowers large, trumpet-shaped, orange red in summer. Recommended for arbors, rocks, brightening of hedges or over old trees or logs. A strong, high grower.

\section{WISTARIA, Chinese}

Produces excellent effect; a very heavy climber unless frequently pruned, when first planted are likely to be slow growers.

WISTARIA WHITE-An attractive and strong grower with a large number of hanging peashaped, white flowers. June.

WISTARIA PURPLE-A beautiful climber of very rapid growth, producing long, pendulous clusters of pale, blue flowers in June, also in fall; is perfectly hardy and one of the most superb climbing vines ever introduced. 


\section{Ornamental and Shade Trees}

B $Y$ all means plant shade trees. They are effective ornamentally from the time they are set out and soon their spreading growth will create a sheltered environment for the home that will be a pride and joy with the passing years. Contrast the heat and glare of downtown streets on a hot summer day with the inviting coolness and beauty of a well shaded residential avenue. Shade trees make the difference and the nominal outlay for planting is returned a hundredfold in greater property value and the enjoyment of pleasant surroundings.

AILANTHUS (Tree of Heaven)-A native of Japan. A rapid growing tree with feathery, tropical foliage. Will thrive in poor soil. Excellent for city planting.

AMELANCHIER (June Berry or Shad Blow) A great profusion of white flowers early in April, followed by small purple fruit ripe in July. One of the best early flowering trees.

ASH, AMERICAN WHITE-A well known native tree. Desirable for lawn and street planting.

BIRCH (Canoe)-A native tree with brilliant white bark. Leaves large and handsome.

BIRCH (European White)-A fine tree of moderate size. Bark silvery white; spray-like branches.

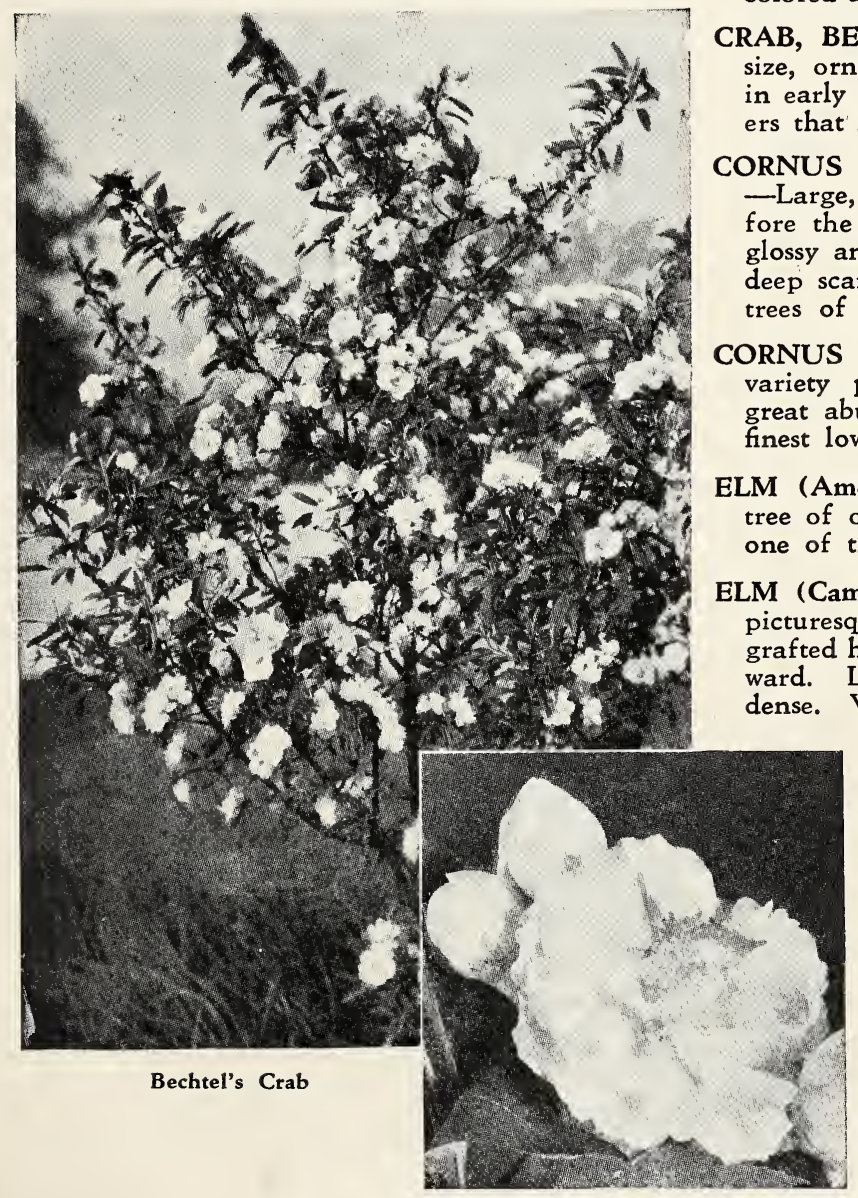

CATALPA BUNGEI (Umbrella Tree)-Grafted on stems 4 to 7 feet high it makes an umbrella shaped top without pruning; perfectly hardy and flourishes in almost all soils and climates. Leaves large, glossy, heart-shaped, deep green; always making a symmetrical head. A very unique tree. Very desirable for formal effects, or for lawn, park and cemetery planting.

CATALPA SPECIOSA - A highly desirable tropical appearing tree with large, fragrant, purple and white flowers. Flowers abundantly in June. The trunk is straight and smooth.

CHERRY, JAPAN WEEPING (Rose Flowered) -One of the finest pendulous trees for lawns or small grounds. Branches are slender and fall gracefully to the ground. Flowers are rose colored and appear before the leaves. May.

CRAB, BECHTEL'S FLOWERING-A medium size, ornamental tree of great beauty, covered in early spring with double pink fragrant flowers that look like roses at a distance. May.

ORNUS (Dogwood-Florida White-Flowering) -Large, white flowers produced in spring before the leaves appear. Foliage grayish-green, lossy and handsome; in the fall turning to a deep scarlet; one of the most beautiful colored rees of that season. May.

CRNUS (Red Flowering) - A rare and beautiful ariety producing deep, rose-pink flowers in great abundance in early spring. One of the nest low growing trees.

A noble drooping, spreading tree of our native forests; a rapid grower and one of the finest trees for street and park.

Camperdown Weeping)-One of the most prafted high, the top spreads outward and downward. Leaves are large, dark green and very dense. Very popular for the lawn.

HORSE CHESTNUT-A beautiful, well-known tree, forming a round, compact head, with dark green foliage and large spikes of white flowers, slightly marked with red. A very hardy and desirable tree for shade.

JUDAS TREE or RED BUD-Very ornamental native tree, medium size with heart-shaped leaves, glossy green above and grayish green beneath. Derives its name from profusion of reddish purple flowers which bloom before foliage appears. April. 


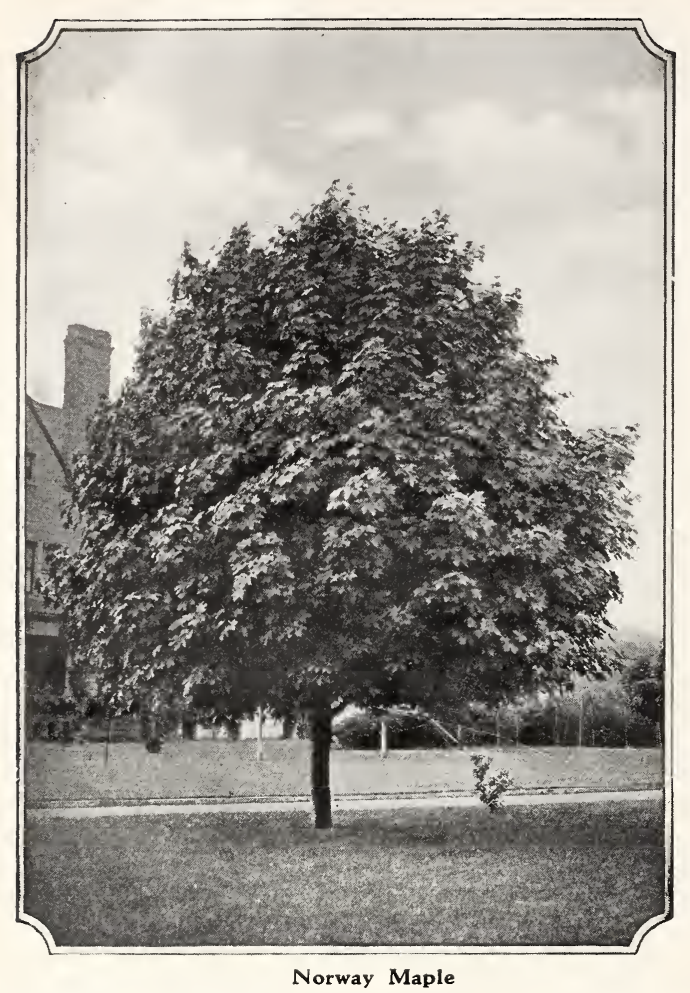

LARCH EUROPEAN-A beautiful, rapid-growing tree, of irregular, pyramidal form, with small drooping branches; valuable for timber.

LABURNUM (Golden Chain) - This is a native of Europe with smooth, shining foliage. It bears long, pendent racemes of golden flowers in June. Showy.

LINDEN, AMERICAN (Basswood)-A rapidgrowing, open head or spreading tree with large leaves and fragrant flowers. Very desirable on account of its fine, luxuriant foliage.

LINDEN, EUROPEAN-Pyramidal in form. Its abundant foliage forms a dense shade. Flowers fragrant. Valuable for street and lawn planting.

LOCUST (Black)-An ornamental tree of rapid growth. Bears pendant racemes of yellowish. white flowers in June.

LOCUST (Honey)-A rapid growing native tree with delicate foliage. Yellowish-green flowers ap. pear in early summer, followed by flat pods 8 to 10 inches long. Excellent for tall hedges.

LOCUST (Moss)-A low growing variety of spreading growth with long, elegant clusters of rose-colored flowers in June.

MAPLE, ASH-LEAF (Box Elder)-A fine, rapid growing variety with handsome light green foliage and spreading head; very hardy, desirable for street planting and succeeds in many places where other varieties do not thrive.

MAPLE (Ginnala)-A graceful small tree or shrub, native of China and Japan. Bright green foliage, turning to a brilliant red in autumn. Handsome and desirable for a lawn specimen.

MAPLE, NORWAY-A distinct foreign variety, now very popular here on account of its clean, broad foliage of deep green. Has a round, com. pact head. A stout, vigorous grower. Very desirable and universally planted.

MAPLE, SILVER-LEAF-If a quick growing tree is desired, we recommend the Silver-Leaved Maple. This is a hardy, rapid growing native variety of the largest size; foliage bright green above and silvery beneath. Excellent for street planting.

MAPLE, SCARLET (Red)-Another native tree, but of medium size. Red blossoms appear in the spring before the leaves. Foliage green, changing in the autumn to most gorgeous tints. Highly ornamental.

MAPLE, SUGAR OR ROCK-This is a wellknown native tree, valuable alike for its production of sugar and wood. Its stately form and rapid growth make it desirable as an ornamental shade tree.

MAPLE, WIER'S CUT-LEAVED-A beautiful variety with delicately cut leaves and graceful, drooping branches. Vigorous grower. While it makes a large tree if undisturbed, it will bear any amount of pruning and may be easily adapted to small lawns.

MOUNTAIN ASH (American) - A favorite, erect growing tree of medium size, producing white flowers early in the spring followed by clusters of bright red berries which remain on the tree through the winter months.

MULBERRY, DOWNING-The beauty of this as a street or lawn tree is quite enough to com. mend it, but in addition it yields an abundant supply of its large, refreshing berries for about three months.

MULBERRY, RUSSIAN-A hardy, rapid grow. ing tree. Foliage abundant; valuable for windbreak. Fruit of little value.

MULBERRY, TEA'S WEEPING - The most graceful and hardy tree in existence. Wholly unlike anything heretofore introduced. Forms perfect umbrella-shaped head with long, slender willowy branches, drooping to the ground. All who have seen it agree that in light, airy grace. fulness, delicacy of form and motion, it is without a rival. One of the foremost among the weeping trees; has beautiful foliage and is wonderfully vigorous and healthy. Safe and easy to transplant. Admirably adapted for orna. menting large or small grounds and also for cemetery planting.

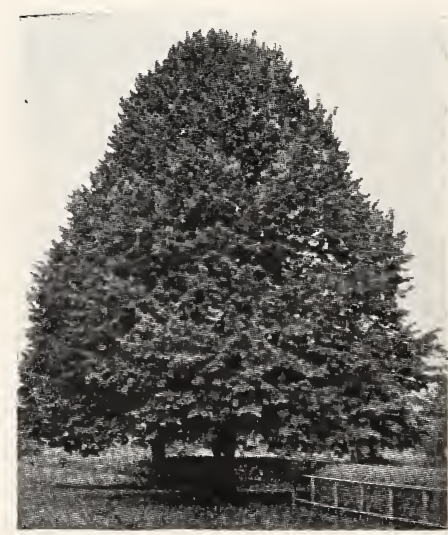

American Linden 


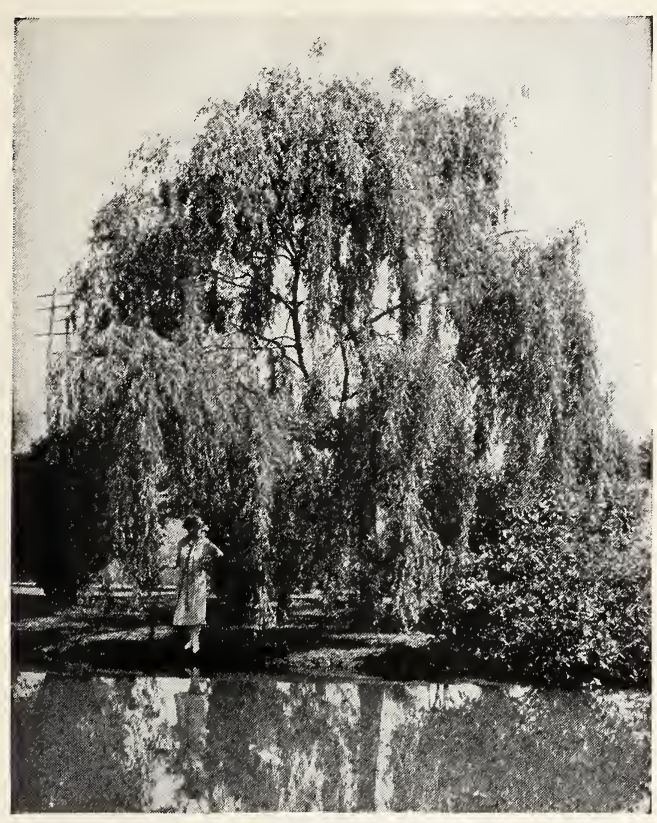

Wisconsin Weeping Willow

OAK, AMERICAN WHITE-One of the finest of our native trees; of massive size and spreading branches. Leaves lobed, green above and glaucous beneath, turning purple in autumn.

OAK, SCARLET-Another native tree of quick growth, pyramidal in form. The leathery leaves turn to a bright scarlet in autumn. A good street tree.

OAK, PIN-Foliage deep green, finely divided; assumes a drooping form when it acquires age. One of the most valuable; fine for streets.

PEACH (Double Rose Flowering) - Flowers double, pale rose colored, like small roses. Very attractive.

PLANE, ORIENTAL-One of the most popular and picturesque trees in America for street or park planting. It is a large tree, symmetrical in contour of head with large, deep-green, heartshaped leaves. Withstands city dust and smoke and seems to be particularly resistant to insect pests and twig blight. The bark, which gives the tree its winter beauty, is mottled by dark blotches of older bark which peels off, leaving a creamy white beneath. An excellent tree for planting in new streets where rapid growth is desired.

POPLAR, CAROLINA-Rapid, luxuriant grower. Large, dark, glossy leaves. Thrives in any soil.

POPLAR, LOMBARDY-Well known' for its erect, rapid growth and spike-like form; not as good for shade as the Carolina.

SALISBURIA (Maiden Hair Tree)-From Japan. One of the most beautiful of lawn trees. Of medium size, rapid growth and rich, glossy, fern-like foliage. Rare and elegant.

THORN, PAUL'S DOUBLE SCARLET-Flowers bright carmine red. Superior to any of its color. Very fine for small grounds. Fruit very ornamental. Will thrive in any soil. May.

THORN, DOUBLE WHITE-Has small, white flowers. A highly ornamental variety on account of both foliage and flowers. Makes a very striking contrast when planted with double scarlet. Strong trees. May.

TULIP TREE-A magnificent native tree with broad, glossy, fiddle-shaped leaves and beautiful tulip-like flowers. Allied to the Magnolias and like them difficult to transplant unless of small size. June.

WILLOW, GOLDEN-For winter effect the Golden Willow is unsurpassed. Its yellow branches very conspicuous; light green leaves.

WILLOW (Laurel Leaf)-Foliage bright shining green, holding well into the autumn. A valuable tree for seashore planting.

WILLOW, Wisconsin Weeping-A common, well known weeping variety. Forms a large, roundheaded, graceful tree. Requires plenty of room and is highly desirable where space is available.

\section{Nut Trees}

BUTTERNUT-A fine, native tree producing a large, longish nut which is prized for its sweet, oily, nutritious kernel.

AMERICAN FILBERT - Smaller and with a thicker shell than the English but of good flavor; hardy and productive.

ENGLISH FILBERT-Succeeds on almost any soil, bears early and abundantly. Larger and better than the native American variety.

HICKORY (Shell-bark or Shag-bark) - The most ornamental and valuable of the genus. The nuts are whiter and the shell thinner than those of other species.

BLACK WALNUT-The common well-known variety, the wood of which is most beautiful and valuable. Very productive in nuts.

ENGLISH WALNUT-One of the largest, most delicious meaty nuts. Not entirely hardy, but trees are bearing nuts in open ground at Geneva, N. Y. It is safe to plant as far north as Philadelphia. Can generally be grown in any climate where peaches are grown.

JAPAN WALNUT - Perfectly hardy; a rapid grower, handsome leaves, bears young and abundantly. One of the finest ornamental trees. Nuts produced in clusters, the shell a little thicker than the English Walnut. Worthy of extensive planting. 


\section{Decorative Hedges}

T

HERE is an unfailing distinction in the appearance of a properly planted and well kept hedge. It outlines in an artistic manner all or a portion of one's private domain and makes an admirable setting for an attractive home and the flowered culture within its borders. When allowed to grow tall it serves as a windbreak for cozy rustic corners and excludes unpleasant views that would otherwise mar the fullest enjoyment of the home and surroundings. It is ideal, when neatly trimmed, for outlining lawns and formal gardens and it implies a privacy that cannot be overlooked.

A good hedge is the result of careful planting. Dig a wide, deep trench and work the soil thoroughly into the roots. Stamp the ground firmly so that each plant will be solidly set and then mulch heavily with loose manure for a foot or more on either side according to the size of the plants.

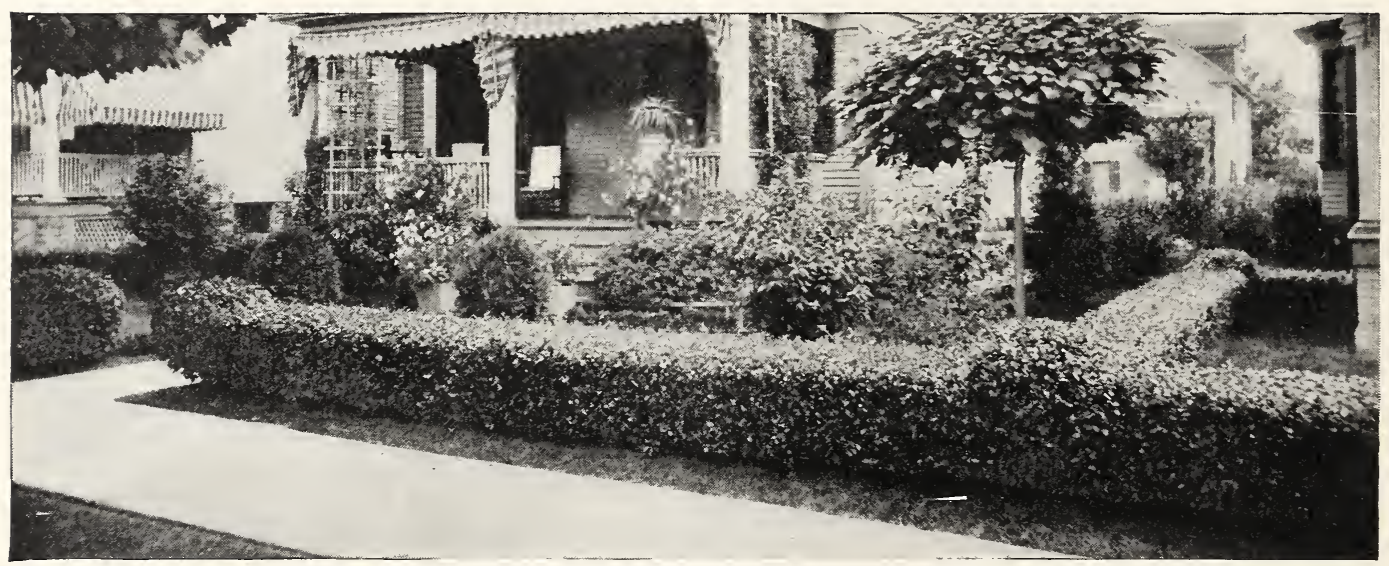

A Hedge of California Privet and a Catalpa Bungei or Umbrella Tree

\section{BARBERRY - Thunberg's}

This popular dwarf shrub deserves particular mention owing to its adaptability and widespread use in lawn groups and boundary hedging. It is sufficiently compact to look well in its natural form, but thrives just as well under the shearing necessary for close cropped formal effects. Yellow flowers in June; scarlet berries in fall that generally last throughout the winter.

CARAGANA (Siberian Pea)-An attractive, small weeping tree, with yellow pea-shaped flowers in clusters.

\section{HONEY LOCUST-Gleditschia triacanthos}

An ornamental tree sometimes planted for defensive hedge. Produces small pink flowers in racemes in May, followed by pods often $1 \frac{1}{2}$ feet long.

\section{JAPAN QUINCE-Cydonia japonica}

One of the most attractive of the spring flowering shrubs. On account of its glossy green foliage and compact habit it makes a fine ornamental hedge. Scarlet flowers in May.

\section{OSAGE ORANGE-Toxylon pomiferum}

A small tree or shrub, semi-hardy in the North, used as a hedge. It is somewhat thorny and bears inedible orange-like fruits.

\section{PRIVET-Ligustrum}

CALIFORNIA (Ovalifolium)-This is the most glossy-leaved and rapid growing of all the halfevergreen plants used for low hedges around private lawns and is the universal favorite at Newport and other fashionable seaside resorts.

AMOOR RIVER NORTH-A distinct type which has been hardy in the North. Foliage and habit of growth almost identical with the variety grown in the South. Flowers white, fruit black.

IBOTA-One of the hardy privets that thrives in shady locations. Grows to 5 or 6 feet untrimmed. Oval leaves, dark, grayish green, turning wine color in fall. Has fragrant flowers in June and black berries in fall and winter.

REGEL'S-Considered the finest of the Privets for shrubbery borders. Clear cut, fine foliage, and a bush of refined habit. The low-spreading, horizontal branches also make it a very fine plant for low hedges. Plant deeply in a hedge planting, giving the plants a severe trimming, and they will make a bushier, more compact hedge.

The following are also very desirable for ornamental hedging, description of which will be found under the proper headings in this catalogue:

Altheas, Barberry, Honeysuckle Tartarian, $\mathrm{Hy}$ drangea Paniculata, Roses, Spireas.

Arbor Vitae, American; Arbor Vitae, Siberian; Norway Spruce (especially adapted for wind. breaks). 


\section{Evergreen Trees and Shrubs}

CTRIKINGLY ornamental in either its tall, stately groups or in the dwarf varieties, for lawn decora$\checkmark$ tion or landscape work. The smaller varieties, when used for foundation planting, seem to blend the house and lawn into a pleasing suggestion of permanency and well-being. Tastefully arranged, they unquestionably enhance realty values. The picturesque leaf masses are enjoyable in the summertime for their harmonizing color effects, ranging from lightest to deepest greens, soft toned grays and blues. Are doubly desirable in the wintertime for the touch of life and color they lend to the bleak December landscape.

\section{ARBOR VITAE-Thuya}

\section{American-}

A native tree of extreme beauty. Known as the white cedar; especially valuable for hedges.

Biota Orientalis-

(Chinese or Oriental Arbor Vitae)-A handsome tree, forming a bushy pyramid.

\section{Globosa-}

(Globe-headed Arbor Vitae) - Grows in low, thick globe form; very desirable.

\section{Hoveyi-}

(Hovey's Golden Arbor Vitae) - Of dwarf habit, globu. lar outline and golden green foliage; fine and hardy.

Pyramidal-

Grows upright with compact habit. Very desirable.

\section{Siberian-}

Claimed to be the best. Exceedingly hardy, grows compact and pyramidal, keeping its color all winter. Extra fine for hedges or screens.

Tom Thumb-

Very dwarf and of slow growth; of compact, sym metrical habit; valuable where low-growing forms are needed. Forms a low, broad pyramid.

\section{Irish-}

\section{JUNIPER-Juniperus}

A distinct and beautiful variety; erect and dense. $R e$ sembles a pillar of green. Very fine.

\section{Prostrata-}

(Prostrate Juniper)-A low-spreading variety, trailing close to the ground. Foliage bright green, bronzy in winter. Fine for rock work or banks.

Savin-

(Savin Juniper) - Prostrate spreading branches, with somber green foliage. Hardy and well adapted for hillsides, etc.

Tamariscifolia-

(Tamarisk-Leaved Savin)-A trailing variety with dis tinct and handsome foliage, valuable for rock work and edges of groups and borders.

Virginiana Glauca-

(Silver Cedar) - The compact, conical habit of this va riety, combined with its silvery foliage, renders it very distinct and desirable.

\section{RETINISPORA}

Pisifera-

(Pea Fruited Japan Cypress) - Beautiful green, feathery foliage of open growth.

Pisifera Aurea-

(Golden Pea Fruited Japan Cypress)-Same as preceding variety except foliage is golden yellow.

\section{SPRUCE-Picea}

\section{Black Hills-}

(Black Hills) - A beautiful tree with drooping branches and fine yew-like foliage, perfectly hardy.

Douglas-

From Colorado. Large conical form; branches spreading, horizontal; leaves light green above, glaucous bo low.

Norway-

An elegant tree; extremely hardy, of lofty, rapid growth and pyramidal form. The branches assume a graceful, drooping habit when the tree attains 15 to 20 feet in drooping habit when the tree attains 15 to 20 feet in
height. One of the most popular evergreens for planting, either as single specimen trees, or in masses for effect or shelter. It is one of the best evergreen hedge plants. A European tree.

Colorado Blue-

One of the hardiest and most beautiful of all the Spruces; in form and habit similar to the White Spruce; foliage of a light blue or sage color.

White-

A native tree of medium size, varying in height from 25 to 50 feet, of pyramidal form. Foliage silver gray. Very hardy and valuable.

\section{Austrian or Black-}

\section{PINE-Pinus}

Tree remarkably robust, hardy and spreading; leaves long, stiff and dark green; rapid growth. The most valuable for this country.

Mugho-

(Dwarf Mugho) - Of low, dense, spreading growth, with very dark foliage; very hardy.

Scotch Sylvestris-

(Scotch Pine) - A native of the British Islands. A fine robust, rapid growing tree, with stout, erect shoots and silvery green foliage. Very hardy, valuable for shelter

\section{YEW-Taxus}

\section{Cuspidata Brevifolia-}

(Japan Yew)-Spreading habit, short dark green leaves. A very handsome, hardy variety. Rare.

\section{Cuspidata-}

(Japan Yew) - Of upright growth and dense, dark green foliage. Hardy.

\section{NATIVE BROAD.LEAVED EVERGREENS}

Rhododendron Maximum-

Tall growing species excellent for massing. Pinkish white flowers in June.

Rhododendron Catawbiense-

Hardy, free blooming variety, rosy-purple flowers in early summer.

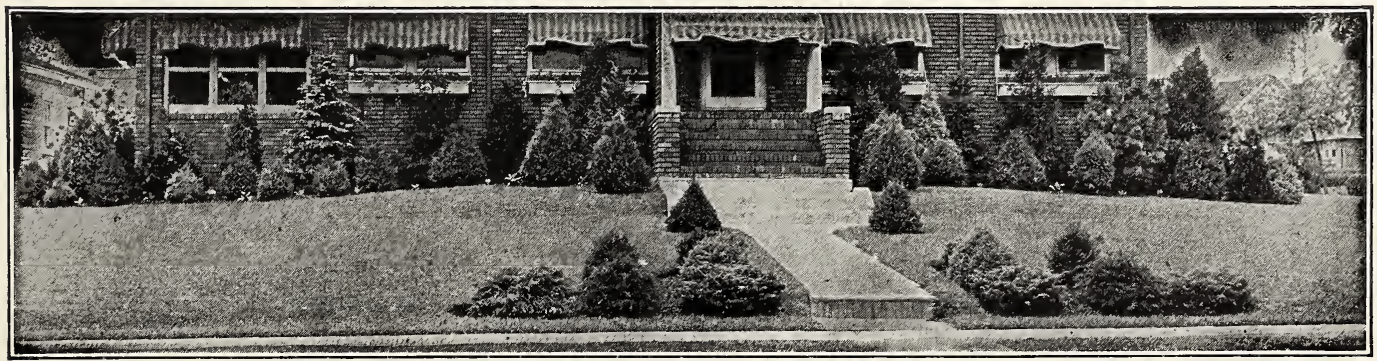

There is real joy in the possession of good Evergreens. For foundation planting they reign supreme over all landscape material. Color, height, form and adaptability with the all year around colorful foliage. 


\title{
Rose Growing
}

\author{
Suggestions on the Selection, Planting and Cultivation of \\ Practical Hardy Varieties Under Average Con- \\ ditions Found in the Home Garden
}

\begin{abstract}
THERE are many delightful varieties of roses, each with a habit of growth and bloom characteristic peculiar to itself. If you have never before grown roses, you have the assurance that the varieties shown on the following pages are standard garden roses that are sure to succeed with only the care necessary for proper rose cultivation. Those who can already point with pride to success in rose cultivation will likely find in these pages varieties with desirable ornamental features that will liven up the average home garden array. With some, the matter of color, size or rarity of blooms are deciding factors, while others base their preference also on size and growth habit of the bush itself and its immunity to diseases to which some varieties are susceptible.
\end{abstract}

Preparation for Planting-The ideal location to grow roses is one flooded with sunshine and with a free circulation of air. Do not plant them too close to trees or shrubbery as the roots of these extend farther than their branches. If the roses are to be planted in bed formation, it is better to dig a trench to a depth of 15 or 18 inches. The soil should be removed, well pulverized and mixed with about one-third its bulk of well-rotted animal manure or a good grade of commercial fertilizer, such as bone meal. Cow manure can be used in fresh condition and is preferred to horse manure, when new, on account of the latter's heating properties. Before filling in the bed, place soft coal cinders or broken crockery in the bottom for drain. age. Cover the roots with fine soil, free from fresh manure, water well and when the water has disappeared fill in the remainder of the soil and pack firmly.

Care of Roses Before Planting-It is usually best to plant roses immediately upon receipt, but if they have been several days in transit, it is sometimes better to immerse the roots for a few hours in water or a rich, thin mud to restore their vitality. Before planting, they should be protected from the sun or drying action of the wind. If plants are received with soil on the roots, it should not be removed when planting.

Planting-Do not set the plants too shallow. Roses on their own roots should be planted just as they stood in the nursery, being guided by the dark earth line. Budded or grafted roses should be set so that the junction of stock and graft is about two inches below surface of soil. Use plenty of water while planting, with a drier soil on top. If the sun is hot, they should be shaded for a few days and watered occasionally.

Pruning and Cultivation-Roses, in practically all varieties, should be cut back about one-third when planted and it is generally advisable to trim the roots a little. Damaged roots should be cut off and any weak or decayed wood removed from the top. Vigorous plants will require less pruning than others. Many of the Hybrid Perpetual varieties, if pruned in July, will continue to bloom throughout the summer. Mound earth around each bush and do not forget to ventilate the soil frequently around the roots by stirring.

Protection of Roses in Winter-This protec. tion depends upon the character of the plants and location. For instance, Hybrid Perpetuals require very little protection, but it is well in the Northern States to give them a protection of strawy stable manure. Evergreen boughs are also used. The tops may be tied up with straw or burlap. This protection should be removed as soon as the danger of hard freezing is over.

Diseases and Insects-Mildew, a disease that frequently attacks the foliage of roses, especially the Crimson Rambler. A light sprinkling of sulphur flour will generally check its spread. A better remedy, if sulphur is not beneficial, is made by dissolving one ounce of potassium sulphuret in two gallons of cold water and applying as a fine spray.

Green Fly or Aphis-A green sucking insect that sometimes gathers in large numbers on the tips of new growth. A solution made from tobacco and insecticide soap will exterminate them.

The Rose Bug-A familiar and destructive insect that usually appears in early summer. Dissolve a quarter pound of hard soap in two quarts of boiling water. Remove from heat and add one pint kerosene oil, stirring violently for about five minutes or until ingredients are thoroughly mixed. Then dilute to twice its bulk with water and apply with a spraying syringe or whisk broom as often as necessary.

Rose Caterpillar-When the leaves come forth in May, examine each plant carefully for a curled leaf or two leaves glued together, indicating that it is a shelter for a caterpillar. Merely pinching firmly between the thumb and finger is an effective remedy.

Black Spot-A disease of fungous nature that appears as a black spot on the leaf which later turns yellow and falls. It usually occurs in the latter part of the season, the Teas being quite im. mune to its ravages. If it has appeared in the past on your plants, a spraying in April, before the foliage appears, with Bordeaux Mixture, will be necessary as a correction.

Saw Fly and Other Insects-Insect pests that are troublesome after the caterpillar are usually destroyed by sprinkling the plants with powdered white hellebore. Moisten the plants well before applying the powder so that it will remain for some time. 


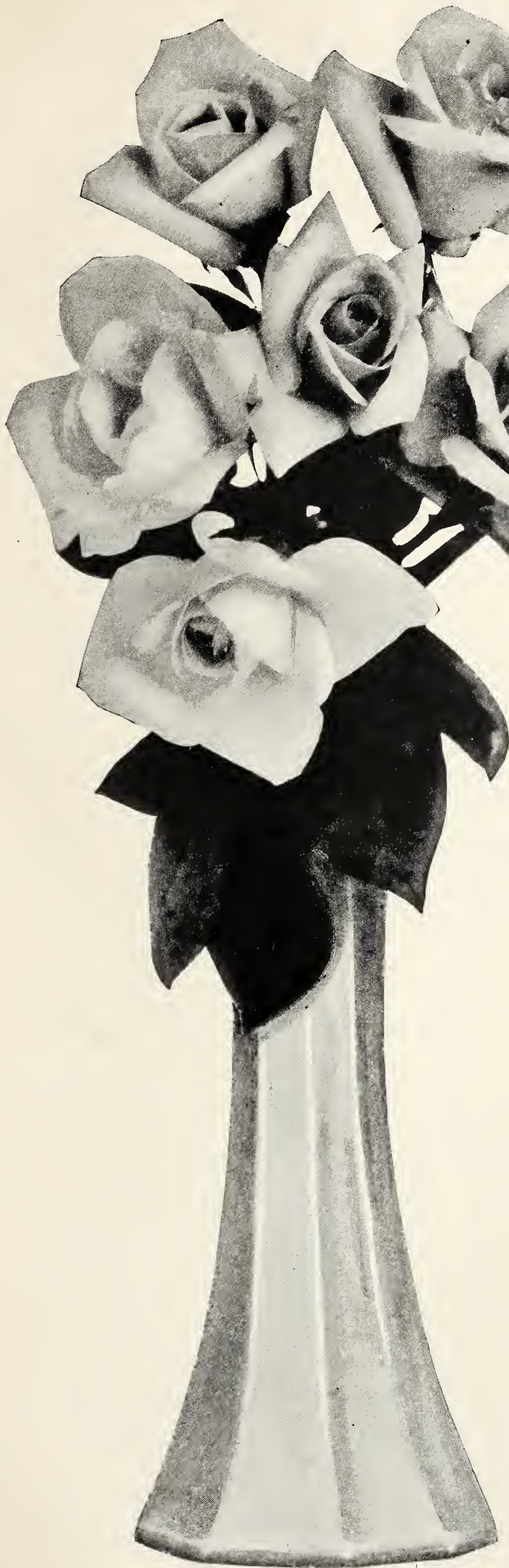

\title{
ROSES
}

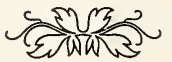

$7 \mathrm{HE}$ varieties listed below are unquestionably the best that can be selected in the Hybrid Perpetual class, which before the development of the Hy. brid Teas, was the most popular type for garden planting, and even now they dare not be overlooked, but should be used extensively in conjunction $w$ it h the other sorts, and especially so in localities where the hardiness of the Hybrid Tea varieties has not been established. The collection here offered embraces as complete a range of colors as it is possible to bring to. gether in such a number of plants, with freedom of flowering, perfect form, fragrance, hardiness and general excellence.

In pruning Hybrid Perpetuals cut away all weak growths, and if quality of bloom is desired, cut back the strong canes to within 8 or 9 inches of the ground, but if quantity of bloom for garden effect is desired, leave these canes from 2 to 3 feet high, according to their strength.

\section{Hybrid Perpetual Roses}

\author{
(Hardy Bush Roses)
}

\section{Old-fashioned June Blooming Varieties}

ALFRED COLOMB-Produces one of the most perfect rose blossoms grown; strawberry-red, with crimson carmine reflexes; very fragrant. The tall, vigorous plants bloom heavily for a long, early sum. mer period.

AMERICAN BEAUTY-The famous Florists' rose. A profuse bloomer; very large and full; brilliant pink to red; delightfully fragrant; borne on long, stiff stems, heavily clothed with foliage.

See colored illustration on front cover.

ANNE de DIESBACH-A most lovely shade of carmine, with very large, moderately fragrant double flowers. A vigorous grower and hardy anywhere in the United States and lower Canada. 


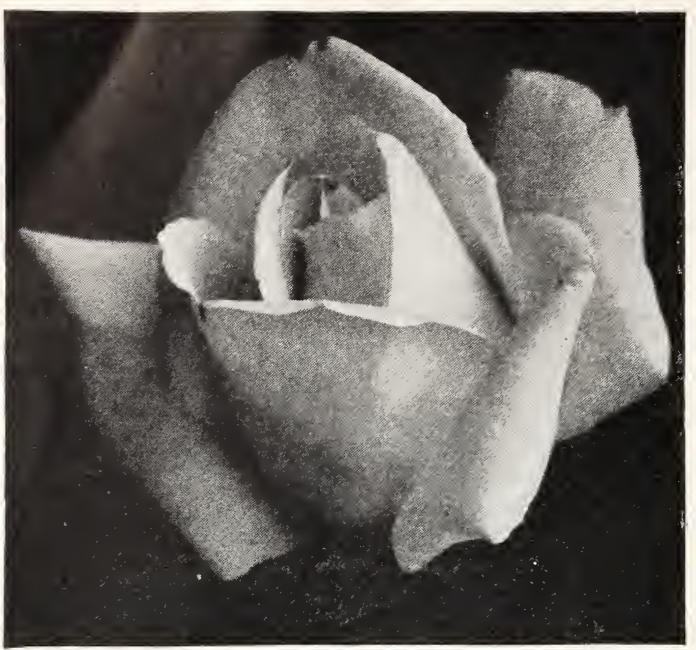

Frau Karl Druschki

BARON de BONSTETTEN-A very desirable hybrid perpetual. A beautiful, dark, velvety crimson flower. The flowers are very large, full and of a delicious odor.

CLIO-A large, globular rose; sweetly fragrant, of satiny flesh color, with a pink center, which, when two-thirds open, is perfectly cup-shaped. The beauty is enhanced by a rosette of foliage about it.

EARL OF DUFFERIN-Very large, full, rich, velvety crimson blooms, shaded maroon and borne on vigorous, free-flowering plants.

EUGENE FURST-Brilliant crimson flowers with dark purple shadings; sweet scented, vigorous and fine.

FISHER HOLMES-One of the choicest of perpetual roses. Bush is vigorous and produces freely of superb blossoms. Color, brilliant, carmine crimson.

FRAU KARL DRUSCHKI (Snow Queen)-An immense, pure white, perfectly double rose, sometimes almost six inches in diameter; abundantly produced in June, and, if kept growing, continues blooming all summer. Plant robust, vigorous and upright. The finest pure white rose in this class. One of the "favorite dozen."

See colored illustration on back cover.

GENERAL JACQUEMINOT-Brilliant crimson; not full but large and extremely effective; fragrant and of excellent, hardy habit.

HARRISON'S YELLOW (Tea)-The yellow rose of our fathers. Small, semi-double, golden yellow flowers, borne in such profusion that the plants are a mass of color. Extremely fragrant.

J. B. CLARK-Intense, deep scarlet blooms of immense size and moderate fragrance. A vigorous grower with strong, upright canes.
JOHN HOPPER-Rosy red, changing to purple carmine; blooms of large, good form and sweetly scented. Plants are bushy, of medium height and very hardy.

LOUIS VAN HOUTTE-Crimson, maroon, medium size; sometimes large, full. A tender sort but very free blooming and altogether the best crimson rose we have. A moderate grower.

MAGNA CHARTA-An old favorite. Very large, full globular bloom of rosy pink, often tinted carmine, remaining on the plants a long time in good condition. A vigorous grower, producing stout canes with many thorns and abundant green foliage.

MADAME PLANTIER-Pure white, medium size, full; flowers produced in great abundance early in the season.

MARGARET DICKSON-One of the most indispensable and highly prized of the Hybrid Perpetuals. A fragrant, white bloom with flesh colored center. The half-opened flowers are very lovely. Plants are vigorous, of compact habit, with large dark green foliage and producing many flowers.

MADAME GABRIEL LUIZET - One of the better $H$. P. roses. Flowers light silvery-pink, shading paler at petal edges, moderately fragrant. A vigorous plant bearing an abundance of bloom.

MRS. JOHN LAING-Very large, long pointed buds opening to immense, full, moderately fragrant and beautiful, soft pink flowers. A low but vigorous growing plant and a profuse bloomer.

MRS. R. G. SHARMAN CRAWFORD - Large, perfectly formed, deep, rosy pink fragrant blooms, the outer petals shaded pale flesh. A vigorous grower and a profuse bloomer.

PAUL NEYRON-One of the best for outdoor culture; probably the largest rose in commerce, the flowers sometimes being six inches in diameter. Fragrant, clear pink blooms, shading to rose; produced by a vigorous, hardy plant.

PERSIAN YELLOW (Tea)-A small, fragrant, double golden yellow flower, borne in great profusion. Desirable for a hedge or for mixing in shrubbery.

PRINCE CAMILLE de ROHAN-A favorite rose because of its finely formed, dark blood red blooms, with strong and pleasing fragrance; it is sometimes referred to as the "Black Rose." Not a strong grower, but worth special attention.

ULRICH BRUNNER-Flowers rich red, fragrant, petals broad, round and thick. A vigorous grow. er and essential in any collection. 


\section{Roses (Hybrid Tea)}

\section{(Everblooming Bush Roses-Blooms from June Until Frost)}

$\mathrm{T}$ HIS class of roses is noted principally for its free and everblooming characteristics, and are commonly called "Monthly Roses." They bloom early and continue to bloom throughout the summer. They are not as hardy as the Hybrid Perpetuals, but can be successfully grown in cold climates, if afforded winter protection.

BETTY-A lovely and deliciously fragrant rose with long buds and coppery rose blooms of informal shape, overspread with golden yellow; plant vigorous; a continuous bloomer, and especially good in autumn.

COLUMBIA-An unusually good American rose. The flowers are large, fully double; bright, lively pink in color; fragrant and borne until late fall. A strong grower, almost thornless.

See colored illustration on back cover.

CRUSADER-An American Rose, producing freely large crimson-red flowers, lighter in the center. Plant vigorous, upright, and good.

DEAN HOLE-An intense salmon-pink, with bud of extraordinary length, opening into a mam. moth bloom of splendid quality and proportions. An English gold medal rose.

DUCHESS OF ALBANY - The medium sized, full open blooms are of very good lasting quality; best described as a red LaFrance.

DUCHESS OF WELLINGTON - Large, wellformed buds, opening to semi-double saffronyellow flowers, stained with crimson and chang. ing to lighter yellow. Fragrant and pleasing and of the utmost possible freedom of growth and bloom, so that it can be depended upon to produce flowers all season. One of the roses necessary in any collection.

EDWARD MAWLEY - A very thrifty grower and of good foliage. Bloom is large, full color, velvety crimson; marvelous in richness.

ETOILE DE FRANCE-The gold medal rose of France. Flowers are large and borne on long, stiff stems; color a lovely shade of clear redcrimson velvet. Very fragrant and keeps well.

FRANCIS SCOTT KEY-An outstanding American variety; extremely large bloom of a rich, crimson-red color; full, very double; borne on long stems of very good lasting quality.

GENERAL MacARTHUR-A very sweet-scented American garden rose of more than ordinary merit. Brilliant, glowing crimson-scarlet buds, opening into full blooms of good keeping qualities. Vigorous, compact, spreading habit, free bloomer.

GEO. AHRENDS-Also known as Pink Druschki. A large and beautiful pink rose, resembling in size and shape of flower the wonderful white Frau Karl Druschki.

GRUSS AN TEPLITZ - An extremely useful and dependable variety, succeeding well all over the United States. A profusion of beautiful, clear crimson-scarlet, fragrant flowers are borne from June until frost on a vigorous and shapely plant. An excellent border and useful also as a hedge, if not cut back.

HADLEY-A deep velvety crimson, retaining its brilliancy at all seasons of the year. Strong, rapid grower. Flowers are borne on long, stiff stems. Its fragrance is unsurpassed.

HOOSIER BEAUTY-A large, full flower with well shaped buds. Color is an exceptionally at. tractive glowing crimson. Very fragrant.

J. L. MOCK -A dependable rose; very large, full and fragrant; petals silvery rosy-white inside, outside carmine-pink. A good bedding variety and a continuous bloomer.

KAISERIN AUG. VIKTORIA-A great favorite. Large, double white blooms on long stems; fra. grant.

KILLARNEY - Large, long-pointed buds, opening to large, loose blooms of flesh-color, borne on long, strong stems.

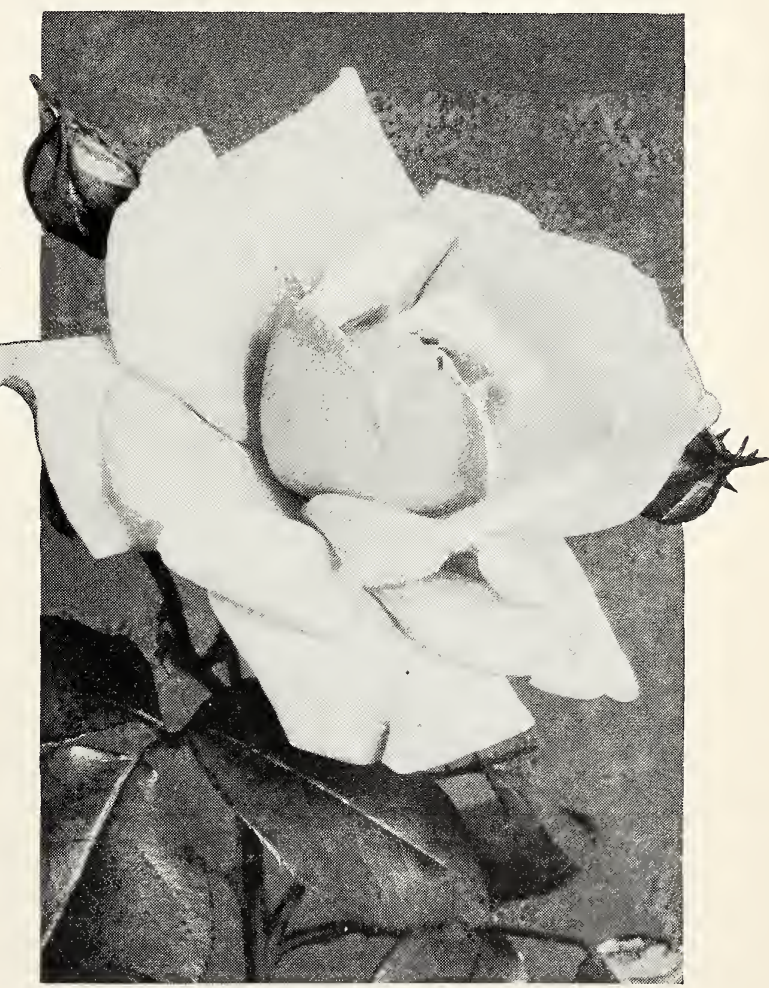

Pink Radiance 
KILLARNEY BRILLIANT-A very much improved Killarney, with more brilliant color, equal perfume and better blooming habit. An in. dispensable rose.

KILLARNEY QUEEN-Another sport of Killarney, with flowers of somewhat darker, clearer pink. Blooms large, well formed on vigorous, free-flowering plants.

KILLARNEY WHITE-Sport of Killarney and very similar to it in size, shape and fragrance, but pure white in color.

LADY ALICE STANLEY-Garden rose of great value. Petals shell shaped, forming a perfect flower. Outside of petals deep coral red; inside delicate flesh of ten flushed with bright pink.

LA FRANCE-The oldest Hybrid Tea Rose and still favorite. Unusually large, long-pointed buds, on long stems; flowers large, very full; the petals bright pink on the outside, silvery pink inside, a very pleasing combination; fragrance unique and delightful. LaFrance does best in poor ground.

LADY ASHTOWN-Deep carmine-pink, shading to a yellow at base of petals. Flowers large, full, high centered; continuous bloomer; a good rose; always recognizable by its beautifully recurved petals.

LADY HILLINGDON (Tea)-The wonderful color of this beautiful rose is equalled by none. It has long, willowy stems that are in no sense weak, as the buds are held upright; has a long, slender pointed bud of brilliant deep golden yellow, improving in color as the flower matures. Awarded gold medal.

LOS ANGELES-One of the most notable American garden roses. Its color is a luminous flame pink, toned coral, shaded translucent gold at base of petals. An upright, sturdy grower, bearing perfect, fragrant flowers on strong stems. Desirable in every garden.

LIEUTENANT CHAURE-Velvety, crimson-red, shaded with garnet; large petals of great depth and nicely cup formed.

LYON-Shrimp pink at edge of petals; center coral-red, shaded with chrome-yellow.

MME. BUTTERFLY - While this is a sport of Ophelia, it shows an even better growth, with more and larger flowers, in a brilliant pink, suffused apricot and gold. These flowers are in the ideal rose form, of good texture and fragrance, and are unusually enduring. The plant is free and fine in growth and habit; among the very best.

MME. CAROLINE TESTOUT-The streets of Portland are bordered with thousands of these roses because the beautiful blooms are borne abundantly all summer on the strong, vigorous plants. The large, rounded flowers are bright satiny rose, with darker center, and edges of petals bordered with soft carmine-pink.
MADAME EDOUARD HERRIOT-Buds corai red, shaded with yellow at the base, the open flowers of medium size, semi-double, are coral red shaded with yellow and bright rosy-scarlet.

MARGARET DICKSON HAMILL-A magnificent rose; its globular blooms are produced in great profusion on vigorous, erect wood with bronzy-crimson leaf stalks, bearing leathery bronze-green foliage; deliciously fragrant and a great acquisition. Flowers delicate straw color. Awarded gold medal.

MRS. CHARLES RUSSELL-One of the popular varieties of the day. Buds long and pointed. Stems long and stiff, surmounted by grand rosypink blooms of large size.

MRS. AARON WARD-A most desirable and dependable rose that will probably produce more flowers than any other yellow rose. Semidouble, cup-shaped, deep Indian yellow flowers; fragrant; blooms until frost.

MY MARYLAND-Strong, vigorous grower and free flowering with double, perfectly formed fragrant blooms. Color, glowing intense pink.

OPHELIA-This highly desirable rose is successful for out-door as well as for greenhouse culture. The beautifully formed, salmon-pink flowers are borne on long, stout stems and are freely produced until frost. Large, dark green, leathery foliage; plant of vigorous, upright habit.

PREMIER-A delightfully fragrant and beautifully formed rich, dark pink rose of good size. Stems long, strong and thornless; plant robust.

REV. F. PAGE ROBERTS-A supremely gorgeous Rose. Copper-red buds, opening to golden-yellow blooms, large and fragrant. Strong plant with healthy foliage.

RADIANCE-A wonderful American production. Vigorous, upright, bushy plants bearing a continuous supply of very large, beautiful, light silvery pink to salmon-pink flowers on long stems. A good bedding variety. The most dependable pink and one of the best for this climate.

RICHMOND-Large, full, fragrant, bright scarlet flowers of excellent quality, with attractive long. pointed buds. Vigorous grower and profuse bloomer.

SOUVENIR de CLAUDIUS PERNET - The long-wanted truly yellow rose. Fine buds and beautiful when half open. Plant erect and strong. Foliage glossy and disease resistant.

SUNBURST-Bright, glowing orange blooms, paling slightly at edge of petal, gives an excellent imitation of a real sunburst. Leathery, bronzy foliage.

\section{The Rugosa Rose Hybrids}

$\mathrm{T}$

HIS class of roses are extremely hardy and will survive the most severe winters. The plant itself is ornamental, and it flowers abundantly in June and then recurrently till fall. It grows 5 to 8 feet high, with wrinkled, dark green foliage, and following the flowers, produces brilliant seed-pods, which hang on nearly all winter. The Rugosas are usually disease-free and need only a very little care. 
CONRAD F. MEYER-Very large, double, showy, clear silvery rose flowers, strongly fragrant, on long, strong stems. The canes are frequently eight feet in height and if carefully trained, can produce some notable garden effects.

F. J. GROOTENDORST-Beautiful, small red flowers in clusters, with the edge of each petal serrated. The plant is a strong grower and bushy, with leathery foliage, and blooms continuously until frost.

HANSA-Large, double reddish violet flowers. The plants are rampant growers and prolific bloomers.

RUGOSA ALBA-Large, single white flowers in clusters on short, strong stems. Vigorous, trailing plants that grow 12 to 15 feet a season.

RUGOSA RUBRA-Large, beautiful, single flowers of clear pink to bright crimson; blooms continuously from June until September, followed by attractive red fruits in autumn.

SIR THOMAS LIPTON-The leading double white Rugosa. Strong growth and typical dark green leaves and large double, pure white blooms throughout the summer.

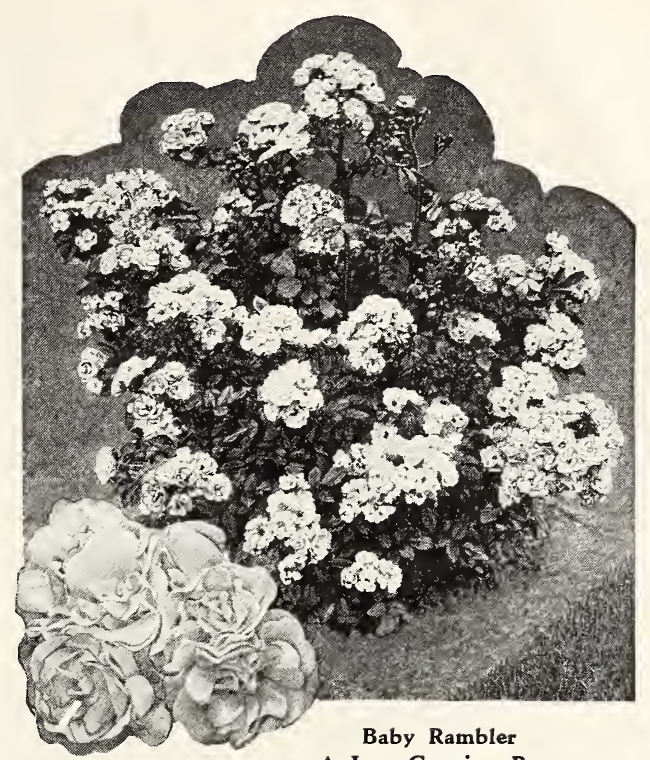

A Low Growing Rose

\section{Dwarf Polyantha Roses}

$\Lambda$ DISTINCT and charming class of roses. They are low-growing, and all summer produce an abundance of clusters of small, perfectly formed flowers. They are ideal bedding plants; planted 50 or 100 in a mass, they can produce very desirable effects. The flowers are effective when cut and because of the size of the bud make very dainty boutonnieres. The plants are hardy.

BABY DOROTHY (Maman Levavasseur) - This latest introduction of the well-known raisers of the now famous Crimson Baby Rambler (Mme. Norbert Levavasseur) is similar in all respects to that variety except that the flowers are of a clear, brilliant pink and very freely produced.

BABY RAMBLER PINK (Anny Muller)-Large clusters of brilliant rose-colored flowers in great

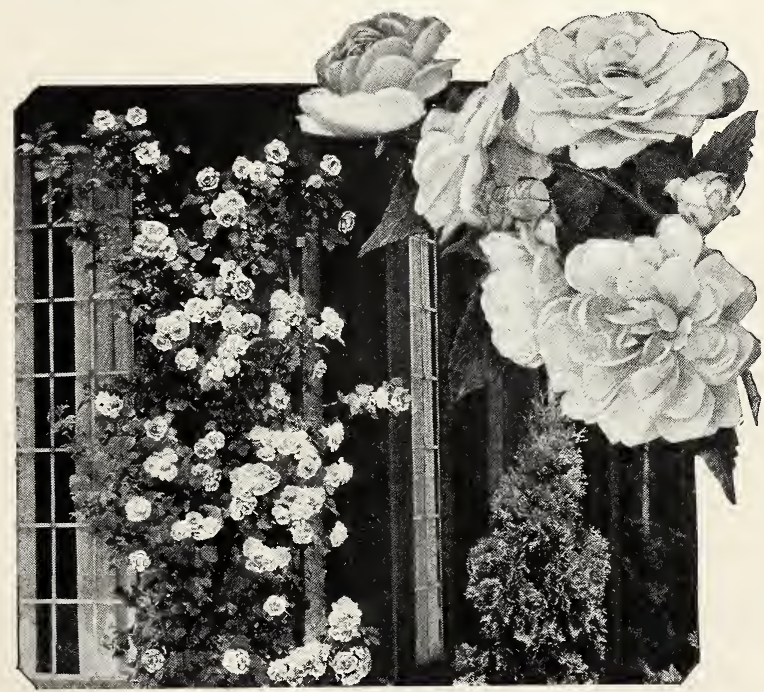

Paul's Scarlet Climber profusion. A splendid bedding variety. Blooms all season until buds are killed by severe frost.

BABY RAMBLER CRIMSON (Madame Norbert Levavasseur)-A dwarf form of the widely known and popular climbing rose, Crimson Rambler, being hardy, vigorous and perpetual flowering. The flowers are large, well formed, of a crimson red color, and borne in clusters.

BABY RAMBLER WHITE (Katherine Zeimet)-Pure white in large clusters; very free flowering.

\section{Climbing and Rambler Roses}

7 HE Climbers and Ramblers afford a burst of bloom and their attractive foliage is an object of beauty when not in bloom. They are most adaptable and can be trained into formal or informal shapes in the garden for hedges, trellises or pillars, or permitted to scramble over an old stump, or beautify a stone pile. These roses grow freely and will endure neglect. 


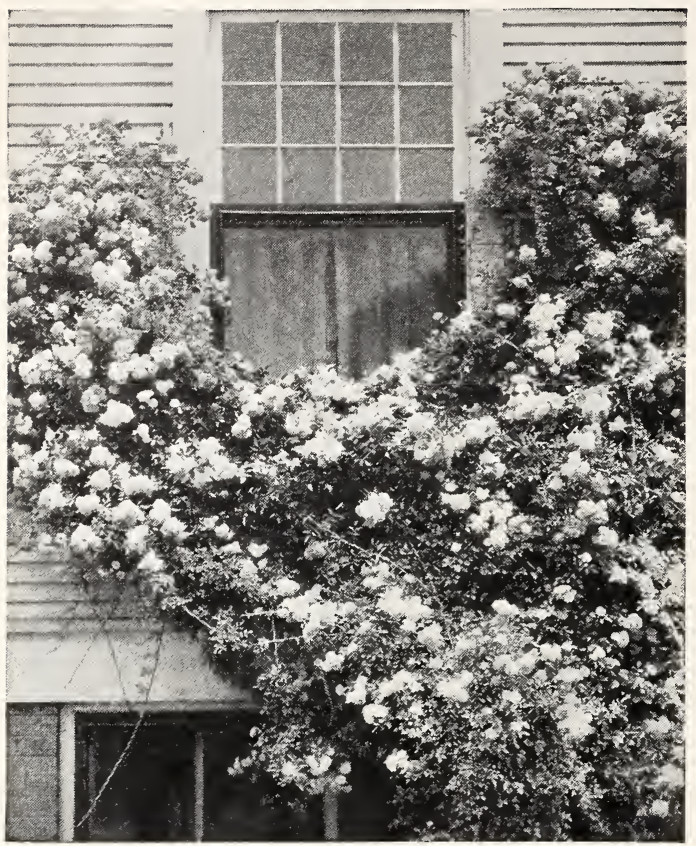

Excelsa Rambler or Red Dorothy Perkins A Wonderful Climber

AMERICAN PILLAR - Very large, handsome flowers of light, bright crimson, with a clear white eye surrounding numerous golden yellow stamens. These flowers fade to an agreeable light pink and are in great clusters. A superb variety.

CLIMBING AMERICAN BEAUTY-The moderately fragrant, rich, rosy, deep pink 3.4 inch flowers are produced in great abundance. It will succeed in almost any situation and makes a very vigorous growth.

CRIMSON RAMBLER-Great masses of crimson, semi-double flowers are borne by these vigorous plants. Desirable pillar and porch plant.

DOROTHY PERKINS-One of the most notable climbing roses. Clear cherry-pink, slightly fragrant; borne in great profusion and lasts a long time. The plant makes a very strong growth; foliage is glossy, bright green, and persists until cold weather.

DR. W. VAN FLEET-Probably the best climb. ing rose in cultivation. Perfectly formed, long pointed, deep pink buds on long stems, with several in a cluster, that opens to a lighter shade of pink. It is a vigorous grower with glossy, dark green foliage. It is a delight to the eye all summer.

EXCELSA-An intense crimson, with the edges of the petals a little lighter, produced in im. mense clusters. Foliage glossy.

FLOWER OF FAIRFIELD - Carmine-crimson, semi-double to double flowers in large, compact clusters; foliage normal; seldom a heavy bloomer.

MARY WALLACE-Early, with perfect flowers of vivid pink hitherto unexistent in climbers.

PAUL'S SCARLET CLIMBER-The brightest and purest red of all the Pillar Roses. Flowers are borne in clusters that retain their color until they fall, the color being intensified by the numerous yellow stamens. A vigorous grower and a good bloomer.

QUEEN OF THE PRAIRIES-An old-time favorite. Bright pink flowers that are sometimes white-striped, in compact clusters. Plant is hardy in any climate.

SILVER MOON - A wonder at bloom-time for its long, well-shaped buds of faint yellow which open into immense pure white flowers, of ten reaching 4 inches or more in diameter. These blooms are semi-double and with very distinctly curled and curved center petals which surround the bright yellow and add piquancy to the whole effect. An indispensable white rose.

TAUSENDSCHON_-The buds are cherry pink, opening to softer shades, all shades being found in a single cluster; has glossy light green foli. age. A highly desirable and distinctive rose for covering walls, fences, porches and pergolas, and unique among climbers.

WHITE DOROTHY - Closely resembles the Dorothy Perkins, except for its immense clusters of pure white flowers. The most valuable white climber of its class.

\section{Moss Roses}

7 HE characters of the Moss Roses are caused by the development of an unusual number of glands, and these glands secrete and give off a very delightful odor. The blooms are attractive in themselves, but having the blooms surrounded by fragrant cresting or mossing gives them added attraction.

BLANCHE MOREAU-Large, perfectly formed, pure white, very fragrant double flowers in large clusters. The plants are vigorous growers.

CRESTED MOSS-Rose colored, sweetly perfumed flowers with beautifully crested buds. The plants are moderate growers and free bloomers.

SALET-Large, full crested buds, opening to large, flat, attractive rose pink blooms that are produced by vigorous plants.

\section{The Wild Rose or Rose Species}

WICHURIANA or Creeping Rose-The Memorial Rose. Beautiful, fragrant, pure white flowers, with a mass of golden stamens, borne in great profusion on a true trailing plant and having dark green, glossy foliage, almost evergreen. One of the latest roses to bloom. 


\section{Popular Old-Fashioned Garden Flowers}

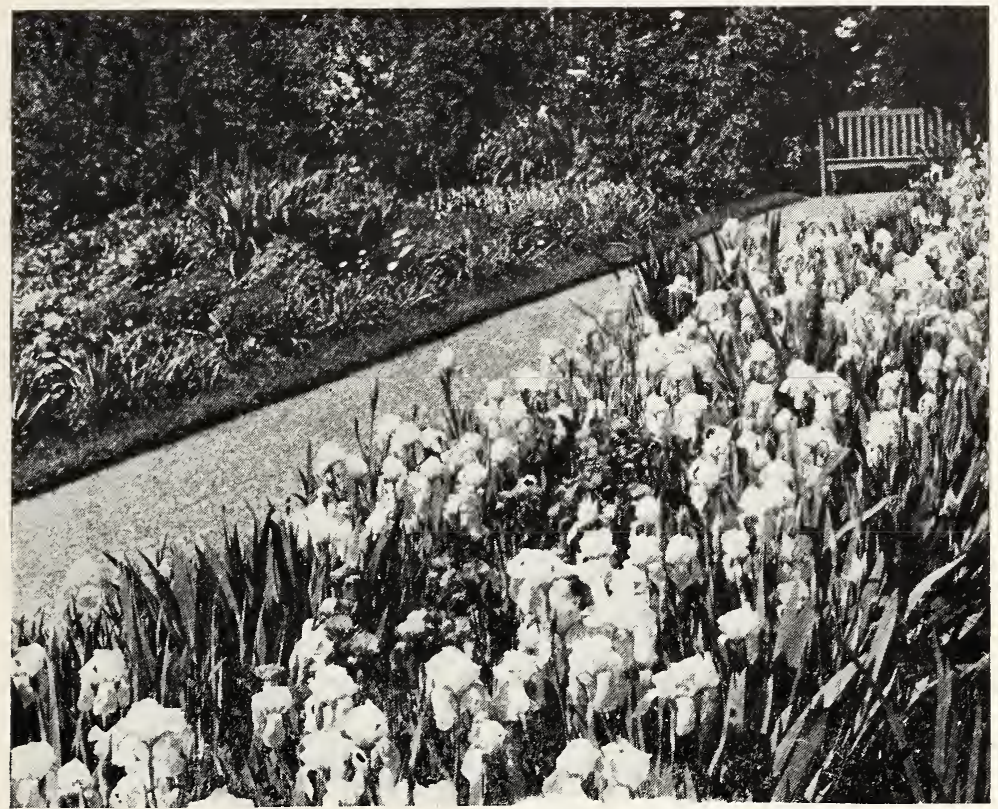

\section{IRIS GERMANICA}

Tlowers that made grandmother's garden a fairyspot of color. ful blooms, are still dear to the heart of the home-maker wherever you go. Summer seems more real 'mid such sur. roundings and $\mathrm{the}$ pleasure derived from their enlivening pro. fusion from s p ring through the later sum. mer months, will amply repay the small initial cost of planting and the slight care they will re. quire. Ofttimes they become the only hobby of elderly stay - at - homes who find exercise and recreation in their cul. tivation.

Masses of Iris along walks or drives add greatly to their interest and beauty.
IRIS is very pleasing planted in groups or when used for border effects. It throws up spikes of bloom that are marvelous in their delicacy of structure and coloring, and the foliage remains fresh and upright after the flowers have been removed.

\section{Hardy Perennials}

ASY to grow, require no special care; once planted, are permanent and among the

$\mathrm{E}$ most satisfactory plants in the garden. Combine Perennials with shrubbery and the effect will be most pleasing. You will have a wonderful mass of color and an unfailing supply of flowers for cutting.

\section{ADAM'S NEEDLE-Yucca Filamentosa}

An impressive evergreen plant; long, blade-like, needle-tipped leaves from which rise striking flowers; stem 4 to 6 feet high, with a profusion of white, bell-shaped flowers. July.

\section{ACHILLEA}

ACHILLEA PTARMICA PLENA-"The Pearl." Double flowering; pure white; especially good for cut flowers. 1 foot. June-July.

\section{ACONITUM}

Summer and late autumn flowering plants with spikes of hood-shaped flowers, thriving in either sun or shade.

FISCHERI-A dwarf variety with pale blue flowers. 1 foot. August.

NAPELLUS (True Monkshood) - Large, dark blue flowers in a raceme. 2 to 3 feet. August. September.

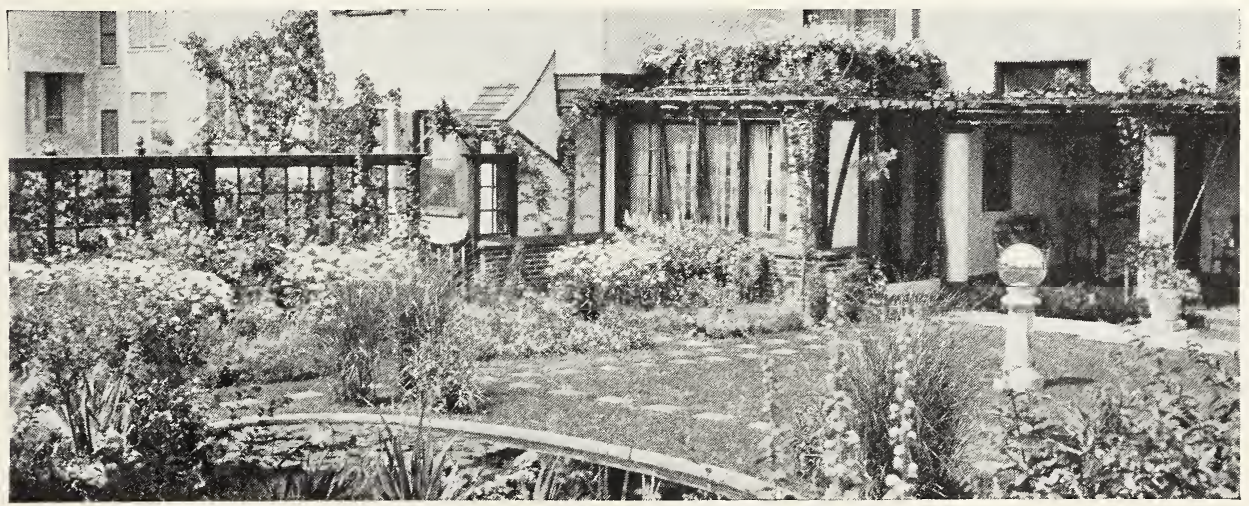

A Charming Garden of Hardy Perennials 


\section{ANCHUSA}

A. ITALICA, Dropmore Variety-Flowers rich blue; growing 3 to 5 feet high. Blooming throughout the summer.

\section{ANEMONE-Windflower}

Japanese Anemones are among the best and worthy of any gardener's consideration because they bloom in fall when flowers are scarce; well adapted for cutting.

JAPONICA - A late blossoming variety, tall and graceful, with dainty, wax-like flowers two inches in diameter. Grows in any location, thriving well in the rock garden or in a half-shaded corner. Blooms from late August to middle of November, when other flowers are scarce.

Alba-Large, white flowers, with yellow stamens. Queen Charlotte-A semi-double flower; large, attractive pink.

Whirlwind-Well shaped, double, white flowers.

\section{BLEEDING HEART-Dicentra}

An old favorite. Flowers heart-shaped in long, drooping racemes; rose color. Very fine for border plants and for forcing. 1 foot. May-June.

\section{BLUE BIRD FLOWER-Veronica}

Should be in every garden. Fine for border planting. The foliage is a very attractive yellowish-green; flowers borne on long, compact spikes. Blooms freely during July and August.

\section{CARNATIONS, HARDY}

Excellent for planting in garden after danger of frosts is past. Will bloom abundantly from July until late fall. Excellent also for forcing indoors for winter. Colors, red, white. 1 foot.

\section{COLUMBINE-Aquilegia}

An old garden favorite and one of the most desirable of the hardy garden plants. Will thrive well in sandy locations where most plants cannot grow. The peculiar shaped flowers with their long, slender spurs, are produced in great abundance on long, graceful stems. A beautiful combination of colors in almost every shade imaginable. Useful for cut flowers. 2 to 3 feet. June-July.

\section{CAMPANULA-Bellflower}

One of the important hardy perennials. Of easy culture, it thrives in either sunshine or shade or in the rock garden. The plant is two or three feet tall and blossoms in June and July and somewhat longer, if in partial shade. Has drooping, bell-shaped flowers in white and various colors, along upright stems with dark green leaves. 2 feet. June-July.

\section{PHYSALIS FRANCHETI}

\section{Also called}

\section{Chinese Lantern Plant}

"Without doubt the most attractive and valu. able hardy plant introduced in many years. A novelty of sterling merit introduced from Japan by the English horticulturist, Mr. James H. Veitch, this alone being a sufficient guarantee of its excellence. It is a gigantic species of the showy Winter Cherry and is of the easiest possible cul. ture. It is of sturdy, upright habit and grows from $1 \frac{1}{2}$ to 2 feet high and is perfectly hardy. It is also highly appreciated as a winter house plant, grown in pots or boxes, and in the spring it can be transferred to the open ground. It blooms early and produces the first season a large number of balloon-like husks 2 to 3 inches across. These first appear light green, then gradually change to bright yellow and finally to an orange scarlet. At this period they resemble miniature lighted Chinese lanterns, hence the name." August-September-October.

\section{CANDYTUFT-Iberis}

SEMPERVIRENS-A distinctive dwarf plant used in gardens and lawns for border purposes. Rare white flowers; very early in April. 6 inches.

\section{CHRYSANTHEMUMS}

A very popular flower in all shades of white, red, orange, yellow and pink. Blossoms in late August or September and continues in bloom into November when other flowers have lapsed into their winter sleep. It is easy to grow, succeeding in almost any kind of soil. Its life and color in the perennial beds and borders entitle it to a place of honor in every garden. 2 to 3 feet.

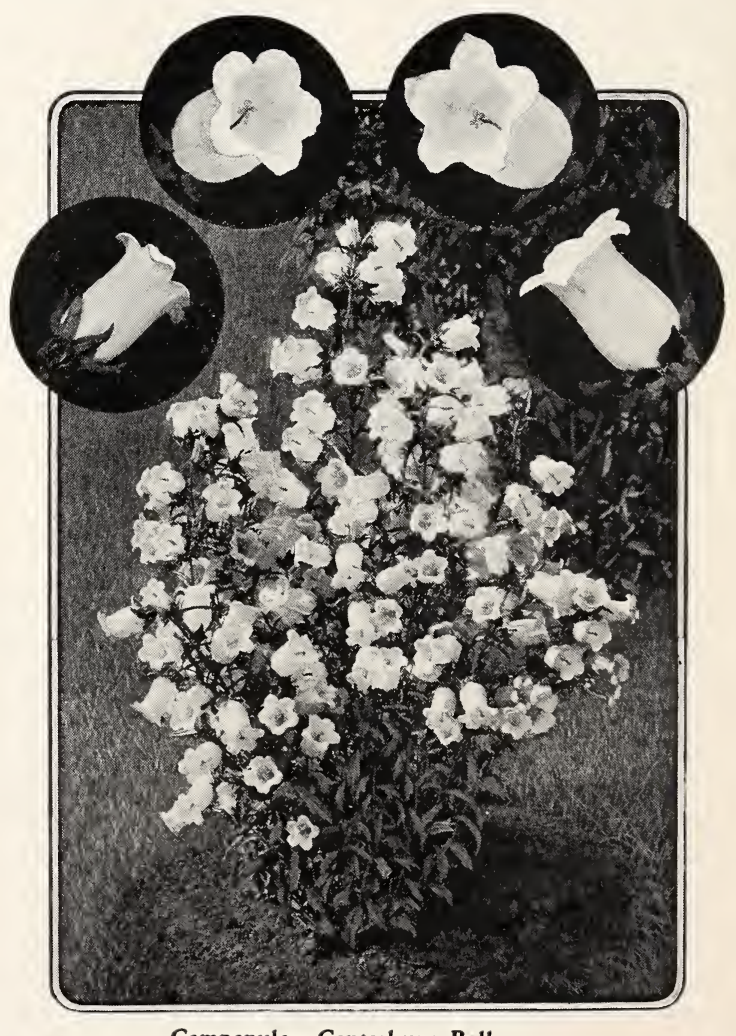

Campanula-Canterbury Bells 


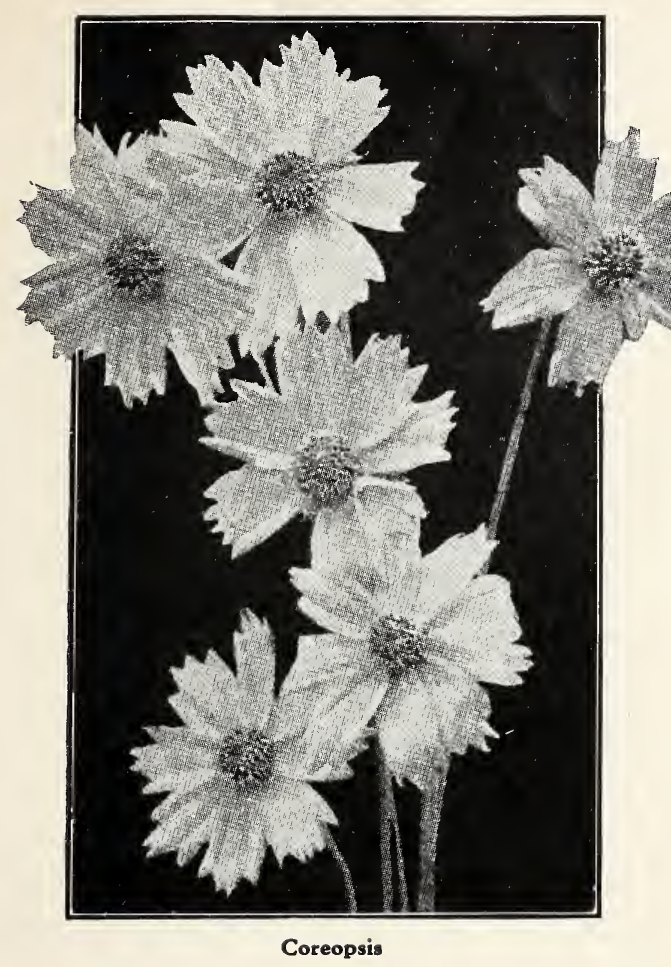

\section{COREOPSIS}

YELLOW-One of the most popular hardy plants. The flowers are of a rich golden yellow, of graceful form and invaluable for cutting; in bloom from June until autumn. It succeeds everywhere. Height $1 \frac{1}{2}$ to 2 feet. A group of these plants furnishes an unfailing mass of rich, glowing color. The plants grow vigorously in any sunny position.

\section{DAISY, SHASTA}

Flowers white, 3 to 4 inches in diameter, borne on long, wiry stems; blossoms when cut remain fresh and in good condition for ten days to two weeks. Very hardy perennial; continues to bloom during several months. 2 feet.

\section{DELPHINIUM OR LARKSPUR}

From among many of the most beautiful hardy plants we select the Delphinium as the most satisfactory border plant-tall and stately, with many shades of blue, and blue and pink combined. 3 to 4 feet. June-September-October.

BELLA DONNA - Turquoise blue, is free and continuous bloomer from the end of June until hard frost.

BELLA MOSUM-A dark blue of the Bella Donna type, with intensely rich blue flowers.

\section{DIGITALIS OR FOXGLOVE}

The Foxgloves are quite stately and highly ornamental plants when well grown, with flower stems at least three feet in height. They are fine for the mixed border, or planted singly in half. shady places near a walk or drive. The racemes of the flowers are often two feet in length, containing scores of prettily. spotted thimble-shaped flowers. Perfectly hardy. Pink, white and purple. June-July.

\section{EULALIA}

JAPONICA ZEBRINA-Leaves crossed every 2 or 3 inches by a band of yellow half-inch wide. Long blades; very attractive for the lawn, bedding purposes or hedges.

\section{FUNKIA-Day Lily}

A beautiful, hardy plant, valuable alike for its white, lily-like flowers and for its dense, glossy foliage. Flowers very fragrant. A good border plant or singly for specimen. Will thrive in shady spots as well as in the sun. 1 to 2 feet. July. August.

\section{GAILLARDIA OR BLANKET FLOWER}

Among the most attractive and effective of our hardy perennial plants. Will thrive in almost any position or any soil. One mass of bloom from June till autumn. The gorgeous flowers, 2 or 3 inches in diameter, dark red in center, with bands of crimson-orange and vermilion, are borne on stems 18 to 24 inches long. When used for filling in front of shrubbery, Gaillardia adds a dash of color which is very effective. June-July-August.

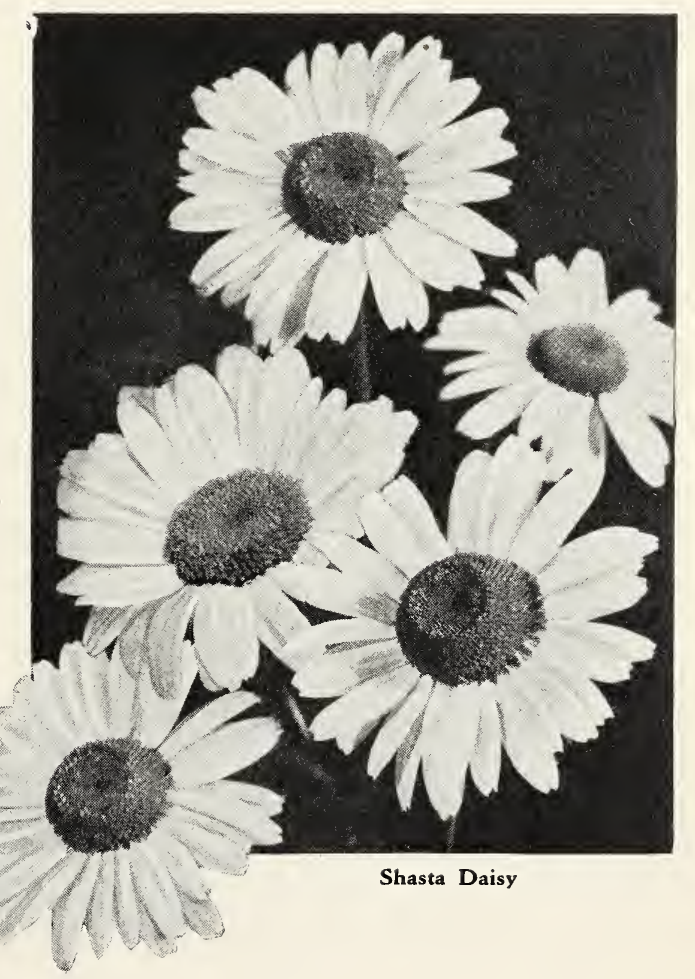




\section{GOLDEN GLOW}

A large, showy plant, attaining in good soil a height of 5 to 6 feet the same season planted. Flowers a deep golden color, resembling yellow chrysanthemums. A profuse bloomer; excellent for cutting. August-September.

\section{GYPSOPHILA-Baby's Breath}

The Gypsophilas will thrive in any soil in a sunny position, and, on account of their gracefully arranged panicles of minute flowers, should be in every garden. 1 to 2 feet. June-July.

PANICULATA-A beautiful, old-fashioned plant, possessing a grace not found in any other perennial. When in bloom, during August and September, it forms a symmetrical mass 2 or 3 feet in height of minute, pure-white flowers, forming a gauze-like appearance. When cut it is exquisite in combination with other flowers.

\section{HEMEROCALLIS FLAVA-Lemon Lily}

The best known variety; very fragrant, deep lemon-yellow flowers in June and July. 2 to 3 feet.

\section{HYPERICUM MOSERIANUM}

"St. John's Wort"-a bushy perennial bearing large, yellow flowers in a great abundance during most of the summer. Very fine. 12 to 18 inches.

\section{LATHYRUS-Perennial Pea}

One of the best and most desirable flowering hardy climbing plants, growing to a height of 8 to 10 feet and producing clusters of large flowers the entire summer. Fine for cutting, lasting well. We especially recommend this.

\section{LILIES-Lillium}

There is no garden flower of greater charm and refinement than the lily. Its many distinct varieties cover the entire range of color, with exquisite markings and perfume. Their blooming periods vary from May until November so that one may select a succession covering the entire year. 3 feet.

AURATUM-Flowers very large, delicate ivory white, thickly dotted with rich, chocolate-crimson spots. A bright golden band runs through the center of each petal. The finest of all lilies.

CANDIDUM (Madonna Lily) - The old fashioned pure white garden lily. One of the hardiest.

\section{ELEGANS-Crimson.}

REGELS-One of the most beautiful and hardiest white lilies in cultivation.

SPECIOSUM ALBUM-Large white flowers with a greenish band through center of each petal.

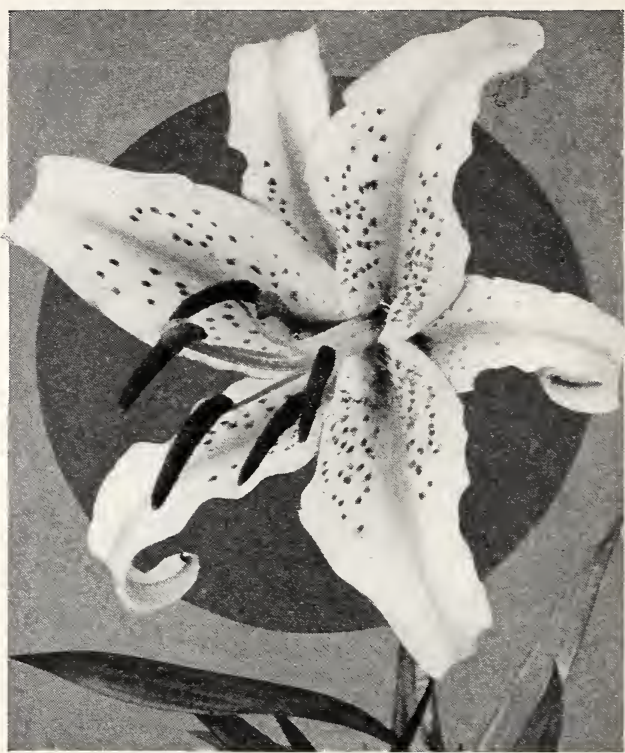

Lily Auratum

SPECIOSUM RUBRUM-Rosy white, heavily spotted with rich crimson.

\section{LILY OF THE VALLEY}

This is often neglected and relegated to some poor out of the way corner, but this popular and fragrant subject, if well treated, will show the effect by increased size, number and vigor of the flowers. It is especially suited for outdoor planting, whicn should be done before the end of April. 6 inches.

\section{MYOSOTIS-Forget-Me-Not}

Charming, low-growing plants, the bright flowers covering the plant in late spring. Hardy and useful in a shady spot in the border. We recommend it as being one of the best. 6 inches.

\section{PRIMULAS-Primrose}

The hardy primroses are among the most beautiful and interesting of our early spring flowers. Plant them in rich, well drained soil, in the border or in a sheltered nook in the rockery; if possible, in a half-shady place. 1 foot. AprilMay.

P. VERIS SUPERBA-A giant flowered form, producing individual flowers from 1 to 2 inches across; in color, they are a bright canary-yellow, with a golden center, perfectly hardy, and, when in flower, present a sheet of bloom.

P. VULGARIS (English Primrose)-An old favorite and should be found in every garden; one of the earliest spring flowers, of bright canary-yellow, very fragrant. 


\section{HELEBORUS-Christmas Rose}

A plant having the unusual characteristic of blooming in the winter time; large, white, solitary flowers appearing in the snow as early as Feb. ruary. Leaves are evergreen. Thrives in rocky places. 12 to 15 inches.

\section{HIBISCUS-Mallow}

A desirable border plant succeeding in any sunny position, but doing best in a damp place; grows four feet high, with large foliage and large, showy flowers of delicate coloring, produced during the entire summer.

GIANT RED - Right in the middle of the summer,

the rich, glorious red flowers of this wonder-

ful creation are beginning to open, and thev continue until frost arrives. Large flowers, 6 to 10 inches in diameter. A very desirable specimen. 3 to 4 feet.

\section{DOUBLE AND SINGLE HOLLYHOCKS}

Are always a necessary part of every Old-Fashioned Garden, either grouped or used as a border or among the shrubbery. Their colossal spikes of bloom produce a bold and showy effect. We offer them in orange, salmon, pink, yellow, red and white colors. 5 to 6 feet. August-September.

\section{IRIS-Fleur de Lis}

GERMAN-One of the most beautiful and showy of the early flowering plants, deliciously fragrant and fine for cutting. In beauty they rival the orchid. Should be in every garden. 2 feet. May-June.

JAPAN-The flowers differ from the above in being broad and flat. They exhibit the most beautiful delicate shades. Perfectly hardy and flower in great profusion in June and July. 2 feet.

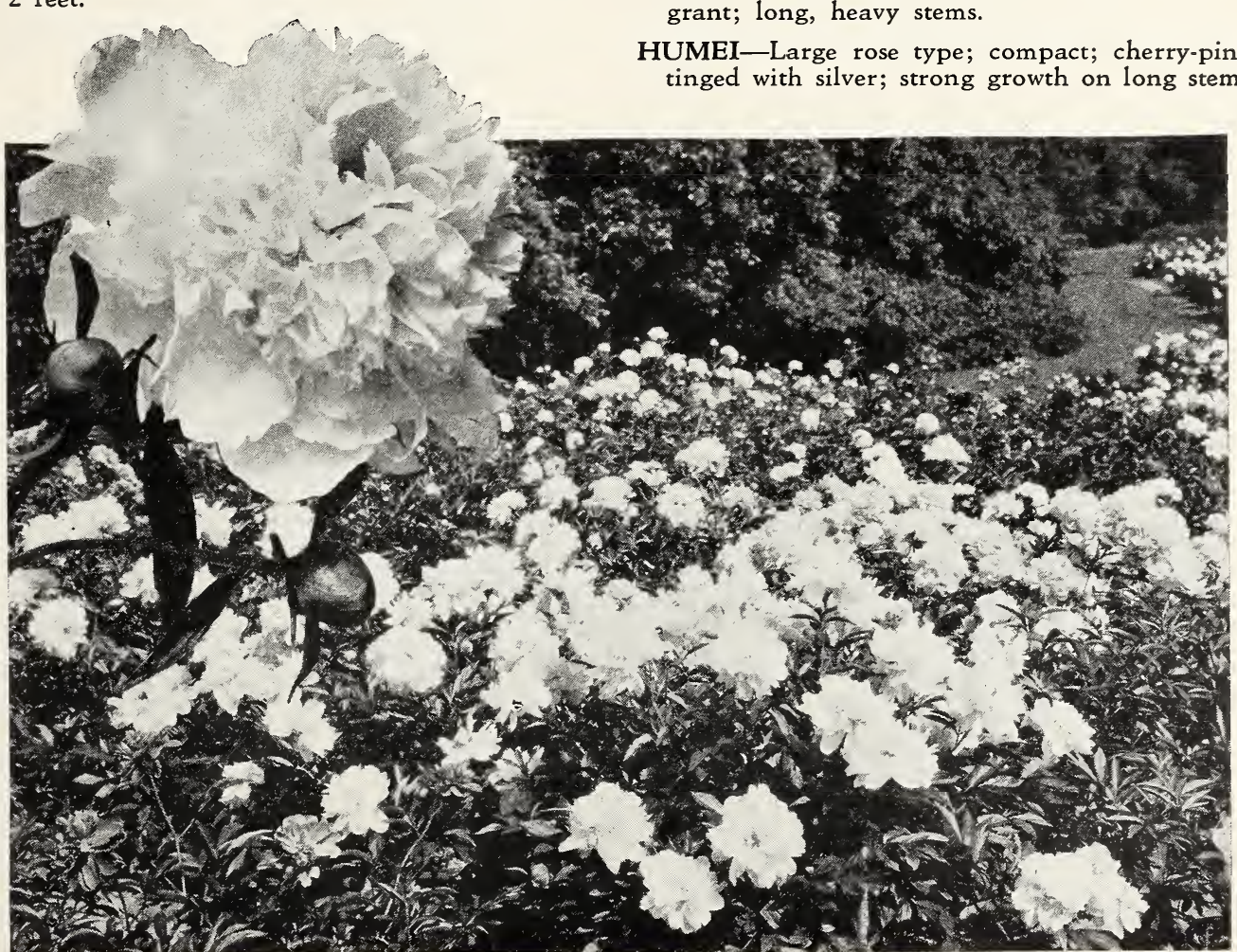

A Superb Peony Planting
A very striking orange-scarlet flower with pur. ple center. These make a brilliant splash of color in any garden. 2 to 3 feet. June.

\section{PINKS-Dianthus}

Among the most esteemed and valuable of hardy plants. Blooms in profusion; great variety of colors. Spicy fragrance. 1 foot. June.

\section{PEONIES}

What garden is complete without the Peony? Can you picture with us a border of peonies, a peony bed, or a hardy garden with here and there a clump of these hardy plants? A large range of color, wonderful large blooms, requiring no special care or attention; any good, deep, well drained soil, with a liberal feeding of sheep manure and plenty of water during blooming time, will produce large and healthy flowers. 3 feet. May. June.

BARON ROTHSCHILD-Very distinctive. Outside petals rose color with salmon center.

DUCHESS DE NEMOURS-Ivory white, tinted with distinctive green markings near the center. Beautiful in bud and when in bloom, fragrant and vigorous.

DUC DE WELLINGTON-Broad, white guard petals; center very full; yellow-white, turning to pure white when in full bloom; fragrant. Stems are strong and tall; flowers abundant.

FESTIVA MAXIMA-Enormous in size and very beautiful; pure white, tinged with purplish-carmine towards the center; rose-shaped; very fragrant; long, heavy stems.

UMEI-Large rose type; compact; cherry-pink, tinged with silver; strong growth on long stems.

\section{POPPY, ORIENTAL}




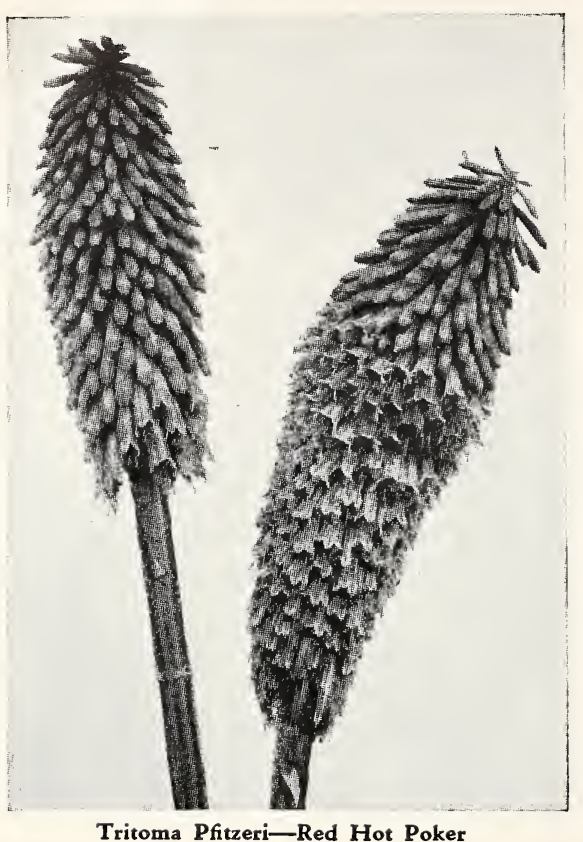

JEANNE d' ARC-Broad, soft outer petals; soft pink and sulphur white, with blush towards the center; sometimes striped with crimson; fragrant.

MADAME de VERNEVILLE-Extra large flow. ers; compact, and literally packed with petals. Petals broad white with slight blush towards the center; delightfully fragrant.

RUBRA SUPERBA-Flowers large; full rose type without stamens. Deep, glossy crimson in color; fragrant, long, stems; blooms freely, but very late.

Write for additional list of named varieties.

\section{PHLOX-Hardy Perennial}

Among hardy perennial plants no class is of more importance than the Phloxes, succeeding in almost any soil and position, and flowering through a long season; and, while they will continue in good condition and flower freely for many years without attention, yet they respond quickly to and are improved by liberal cultivation. 2 to 3 feet. July-August.

COQUELICOT-Bright scarlet.

PANTHEON-Large, salmon-pink flowers.

RICHARD WALLACE-White, violet center.

Write for additional list of named varieties.

\section{PYRETHRUM}

The Pyrethrums are closely related to the hardy chrysanthemum family and are often referred to as spring flowering chrysanthemums. Excellent for cut flower decoration owing to their lasting qualities in water. May-June.

\section{STOKESIA-Stokes Hardy Aster}

CYANEA-A beautiful native plant. Grows from 18 to 24 inches high, bearing freely from early June until October its handsome lavender-blue Cornflower-like blossoms, which measure from 4 to 5 inches across. It is of the easiest culture, succeeding in any open sunny position, and not only is it desirable as a single plant in the hardy border, but it can also be used with fine effect in masses or beds of any size.

CYANEA ALBA-Pure white variety of above.

1 to 2 feet. June to October.

\section{TRITOMA-Red Hot Poker}

Tritomas are one of the great bedding plants; free and continuous bloomers, exceptionally fine for massing. Hardy if given protection. Roots winter best when buried in cool cellar.

T. PFITZERI (Red Hot Poker) - Of perfect form, brilliant scarlet, the opened lower petals merely being trimmed with orange. Bush-like foliage supports smooth, thick flower stalks a yard long with single, fiery cone at the top. 3 feet. August.

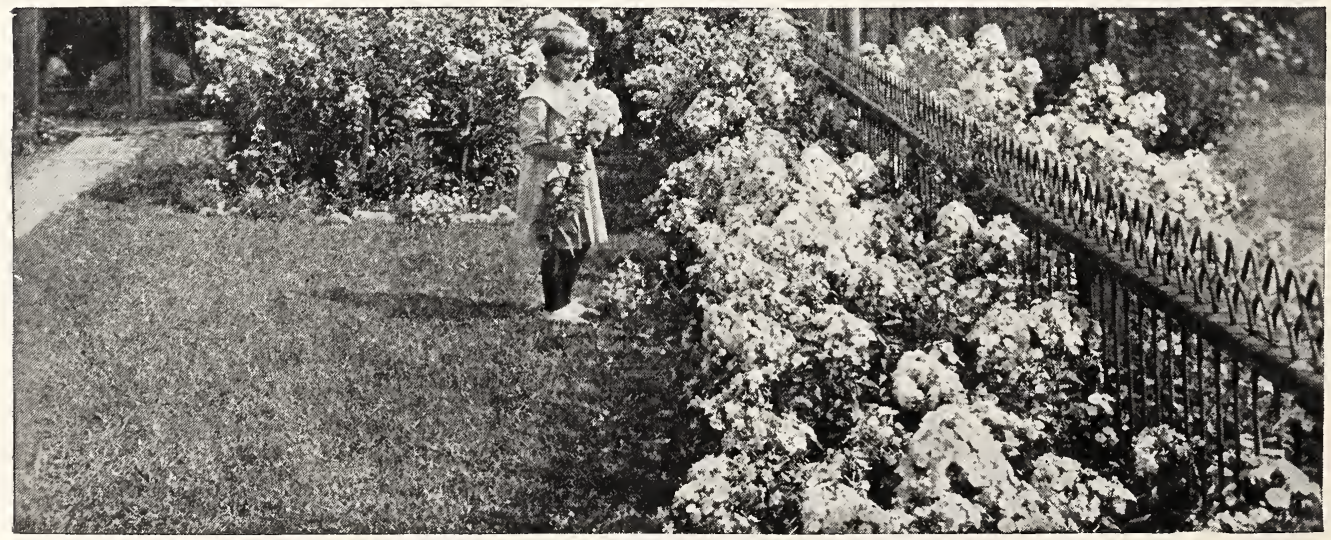

A Pleasing Border Effect of Our Hardy Phlox 


\section{Bulbs and Tuberous Rooted Plants}

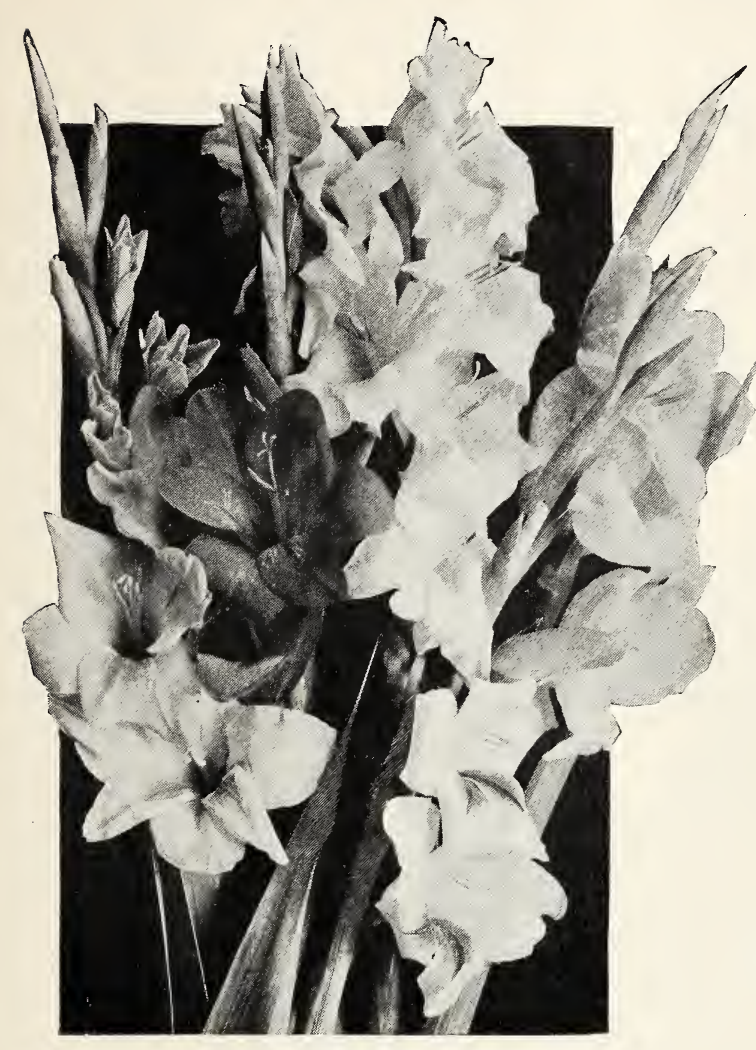

Gladioli

\section{Spring Planting}

\section{CANNAS}

Tall and vigorous, furnishing a wide range of color; fine foliage of large proportion, almost entirely concealing the ground; flower trusses are large and free; brilliant color combinations.

DAVID HARUM-Bright, deep vermilion flowers on bronze foliage.

KING HUMBERT-One of the finest of the Cannas; large, heart-shaped leaves, bronze tinted with purple. Covered with immense orchid-like flowers; individual petals are of immense size, orange-scarlet and carmine in color.

QUEEN CHARLOTTE-Wide band of yellow bordering a center of crimson-carmine.

QUEEN HELEN-This is a new sort from the King Humbert, resembling it to great extent, except the foliage is rich green instead of bronze; the same type of immense flower of brilliant yellow and stem of red.

\section{DAHLIAS}

There is nothing that will give a greater showing of flowers for the money invested, than Dahlias. We offer dry bulbs or tubers.

\section{GLADIOLI}

The most attractive of all the summer flowering bulbs, no garden complete without them. Can be grown with very little care, any rich, light garden soil exposed to the sun will make them thrive. Should be planted from the middle of April on into May in the Northern States. Set bulbs 2 to 4 inches deep and 6 to 9 inches apart. We offer the following colors: white, red, orange, yellow, lavender, pink. Make very desirable cut flowers, as they will last longer in water than most any other flower.

\section{Fall Planting}

\section{CROCUS}

Always a favorite and one of the earliest garden ornaments. Plant about 2 inches deep. Colors blue, white, yellow and striped.

\section{HYACINTHS}

The most beautiful and fragrant of early spring flowering bulbs, much used for winter forcing. Pink, red, purple, violet, white.

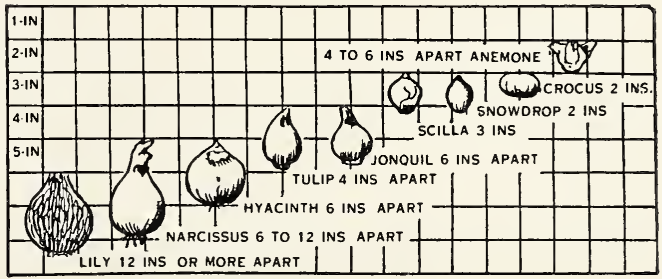

Bulb Planting Diagram

Showing depth and spacing for setting out various bulbs. The bulb bed should be given a winter protection of leaves or straw manure after the ground is frozen in early winter.

\section{TULIPS}

Bare indeed would many gardens be in the early spring were it not for the tulips. Their gorgeous showing is always a welcome one. Very easily grown. Should be planted in October or Novem. ber. 


\section{Apples}

$\mathrm{T}$

HE demand for apples, universally recognized as the king of fruits, is increasing every year, and its growing popularity means a rich harvest for those who plant now. The export demand is increasing, too, as the old world gets a taste of what good fruit is. Orchards can be planted on ground that otherwise would not be desirable for cultivation and, if managed well, will bring big profits. For the home just a few trees selected to give luscious fruit the year round, will bring a royal dividend for their cost and care. Many successful planters plant peach trees between the other trees in an apple orchard. The peach trees can be removed after they are too old to bear and the apple orchard is all the better for their protection.

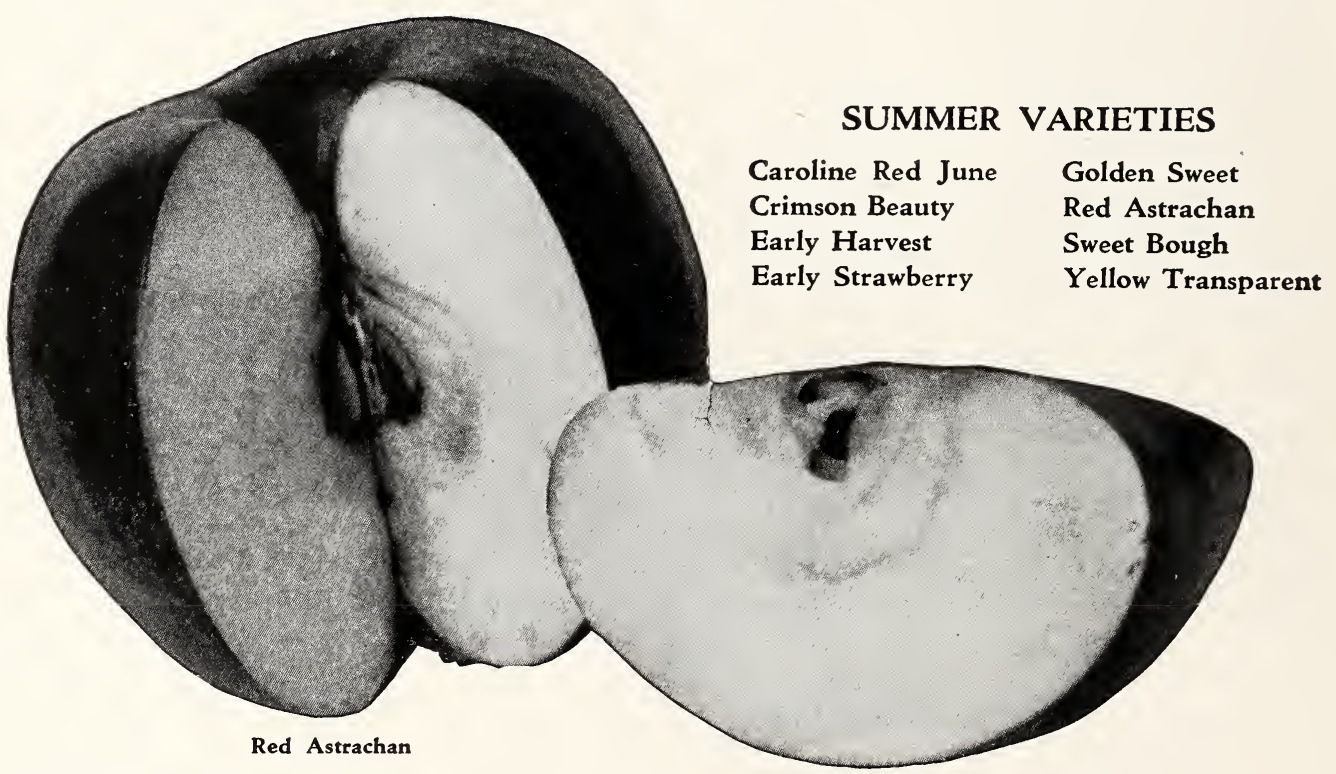

CAROLINE JUNE (Red June)-Popular in the South and West; small to medium, deep red, productive, hardy and a free grower. August.

CRIMSON BEAUTY-Originated in Maine. Very hardy, strong grower and very productive; extremely early bearer, earliest ripening apple known. Just the variety to plant in the home yard. Two year trees in the nursery rows frequently produce fine fruit. Flesh sub-acid, pleasant to eat out-of-hand. Unexcelled for pies and sauce.

EARLY HARVEST-Being a pale yellow with fruit medium and very good in quality. It is one of the earliest of the summer apples and is a very desirable variety for the home. Middle to end of August.

EARLY STRAWBERRY - Tree a moderate, erect grower and good bearer. Fruit tender, mild and fine flavored. Season, middle to end of August.
GOLDEN SWEET-Large, yellow; very fair, sweet apple. Tree a free grower, good bearer. August and September.

RED ASTRACHAN - Good size, covered with thick bloom, deep crimson in color. Flesh juicy and tender. This is an excellent early cooking apple. Tree very hardy, vigorous grower, bears young. July to August.

SWEET BOUGH-A fine apple for baking or to eat out-of-hand, but too perishable as a market variety. Baked whole and eaten with cream it is delicious. Large, pale yellow, tender and sweet. Will grow in all good apple districts. Season, August. Origin, U. S.

YELLOW TRANSPARENT-A good early apple of good quality. Good size, clear white color tinted with pale yellow. Flavor slightly acid. Tree is hardy. Bears young, yielding large crops. Ripens late July and August. 


\section{The Best Fall Varieties of Apples}

\author{
Alexander \\ Duchess \\ Fall Pippin
}

\author{
Fameuse \\ Gravenstein \\ Maiden's Blush
}

\author{
Pound Sweet \\ Rambo
}

\author{
Smoke House \\ Twenty Ounce
}

ALEXANDER - Tree hardy and productive, bears early. Fruit is round and large, with a rich, yellowish green skin, intermingled with russet spots. Flesh white, juicy and snappy; very nice eating apple. Good for cooking and an extra fine shipper. In bearing from September 15 to November 15. Tree hardy; grows almost anywhere.

DUCHESS OF OLDENBURG-Ripens in succession, so that several pickings are required in order to secure the crop. It is in season during August and September, but may be used for culinary purposes before it is fully ripe. The tree is highly valued because of its great hardiness. September.

FALL PIPPIN-Very large, yellow, tender, juicy and rich. A general favorite as a fall cooking apple. Pleasant, aromatic flavor when eaten. Tree is vigorous, hardy and productive, but fruit is quite subject to moss spots. Season, October to December. American origin (probably seedling).

FAMEUSE OR SNOW APPLE-One of the best table apples. Medium size, deep crimson color. Inside is snowy white and delicious. First-class for all markets, and will do well North. Tree is vigorous and productive. Season, October to December. Origin, Quebec.

GRAVENSTEIN-Ripens continuously during a period of several weeks and should have two or three pickings, beginning in the latter half of September. It continues in season till early November.

MAIDEN-BLUSH-Is a beautiful apple of pale lemon-yellow with crimson cheek. The flesh is white and good in quality. It is grown extensively and is in season from September to November or December. It is recognized as a standard market variety and usually sells above the average prices. Season, September and October. Origin, New Jersey.

POUND SWEET (Pumpkin Russet)-A very large, round, yellowish russet apple; very sweet and rich. Tree a vigorous and rapid grower. October and November.

RAMBO-Medium; yellowish, streaked with dull red and somewhat dotted; mild, tender and good. Fine grower, productive; more especially valuable in the West. October to December.

SMOKE HOUSE-Comes into bearing moderately young. It has a thin skin of yellow striped with rather a dull red and is very attractive. October to February or March.

TWENTY OUNCE-Fruit exceptionally large, yellow and red. Juicy and crisp, sub-acid. Tree is vigorous and productive. October to January or February.

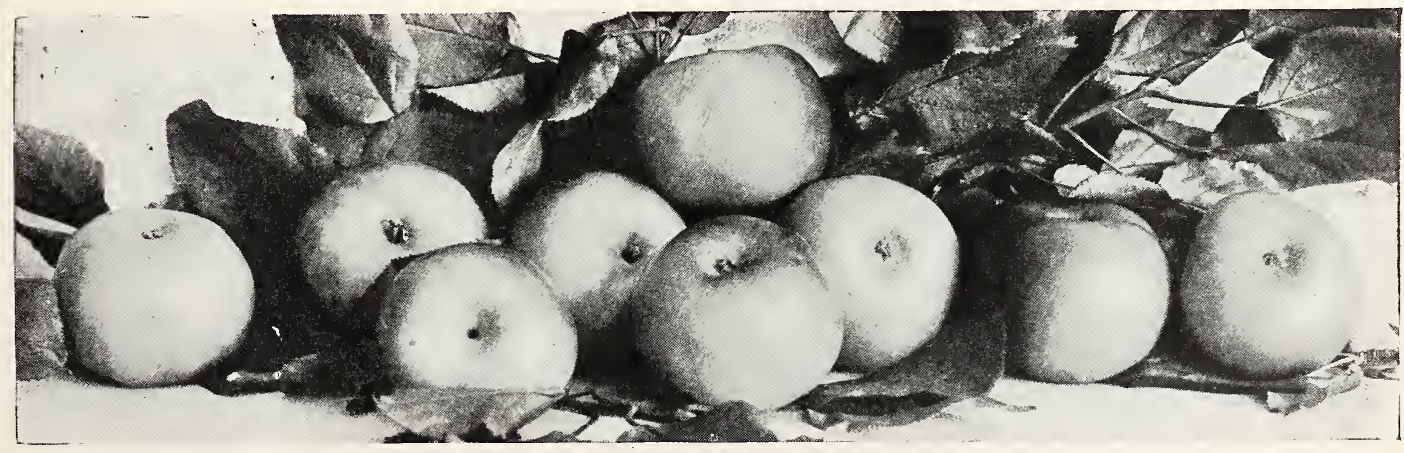

Maiden-Blush Apples

A Productive and Profitable Variety, of Good Appearance, Ripening Early to Command Top Market Prices. 


\section{The Best Winter Varieties of Apples}

Baldwin
Baxter
Bellefleur, Yellow
Ben Davis
Canada Red
Cortland
Delicious
Fallawater

\author{
Gano \\ Greening, R. I. \\ Grimes' Golden \\ Golden Russet \\ Hubbardston Nonesuch \\ Jonathan \\ King of Tompkins Co. \\ Mammoth Black Twig
}

Mann
McIntosh Red
Northern Spy
N. W. Greening
Rome Beauty
Roxbury Russet
Spitzenburg
Stark

Stayman's Winesap

Tolman Sweet

Wagener

Wealthy

Winter Banana

Wolf River

York Imperial

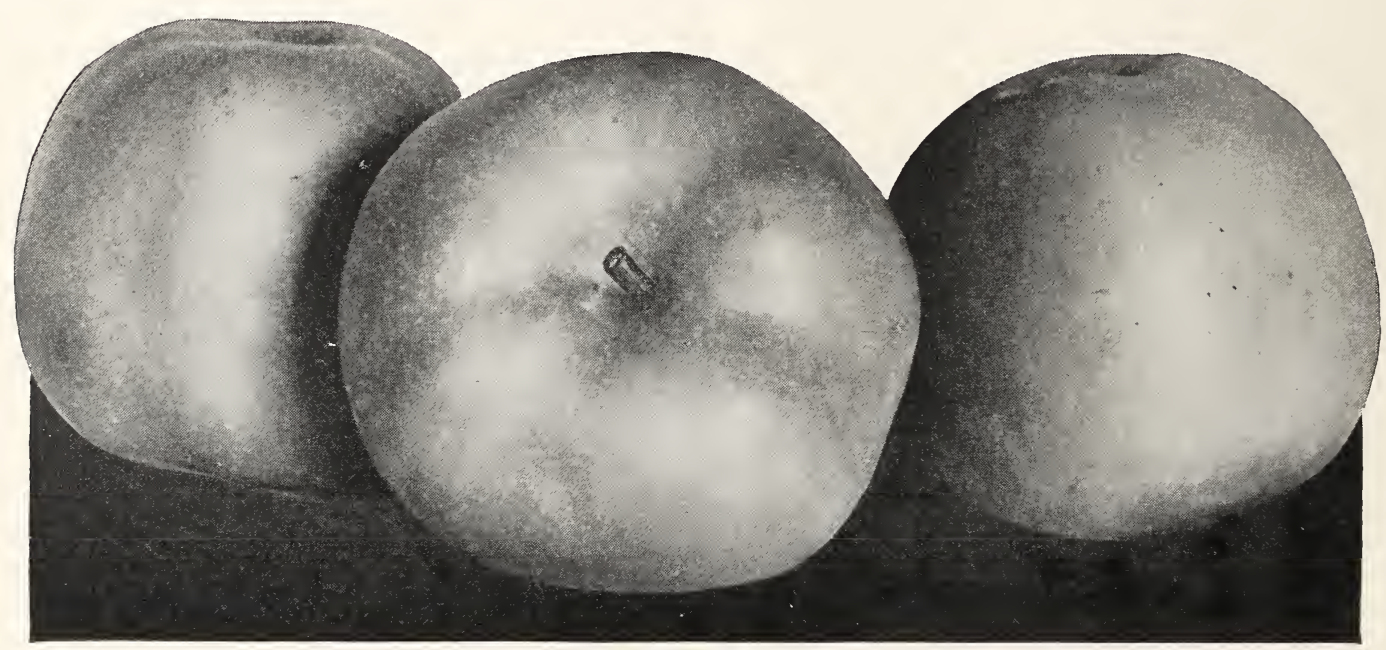

R. I. Greening

A Large, Luscious Apple With Green Skin Which Turns Quite Yellow When Fully Ripe. Flesh is Yellow, Fine-Grained, Tender and Juicy-An Excellent Eating Apple.

BALDWIN-The most popular winter apple for shipping and the heaviest bearer. Baldwin orchards should be mixed with other varieties, such as King, Northern Spy, Russets, etc. The fruit is much better. Tree grows rapidly and its fruit is large, round, with red and yellow skin. Flesh yellowish and tart. One of the best apples for both American and export trade. A fine keeper in ordinary dry cellar. Comes into heavy bearing in eight years. Will bear some in five years. If your orchards are tilled and the trees sprayed and properly trimmed you will bring fruit much quicker.

BAXTER-A fine, large, red apple which brings a big price in all markets. Somewhat subject to fungus. Tree is a good grower, hardy, but only moderately productive. Flesh is white with red streaks; slightly sour; not very juicy, but a firstclass cooking apple. Season, October to January.
BEN DAVIS-Comes into bearing at an early age, bearing annually and abundantly. It is the most important variety known in the apple districts, stretching from the Atlantic to Pacific. This variety is handsomely colored red, and a very thick-skinned apple. December to March.

BELLEFLEUR, YELLOW-A valuable apple because of its good quality all through the winter. Tree is hardy and a strong grower. Does well on light, sandy soils. The fruit is large, yellow with blush on sunny side, crisp and fine flavored in season. Bruises easily, but valuable in home markets. Season, November to April. Origin, Burlington, N. J.

CORTLAND-New. Beautiful, large red apple. Developed by the New York State Experiment Station. It has inherited only the good qualities of its parents, McIntosh and Ben Davis, besides a few of its own. Very firm, and keeps late in winter. 
DELICIOUS - Distinctive in shape and marvelously beautiful in color, remarkable in quality and perfect in tree and blossom. Delicious is large, with the surface almost covered with a most beautiful, brilliant dark red, blending to golden yellow at the blossom end. The calyx, or blossom end, is one of its ever characteristic featureshaving five protuberances more or less pointed

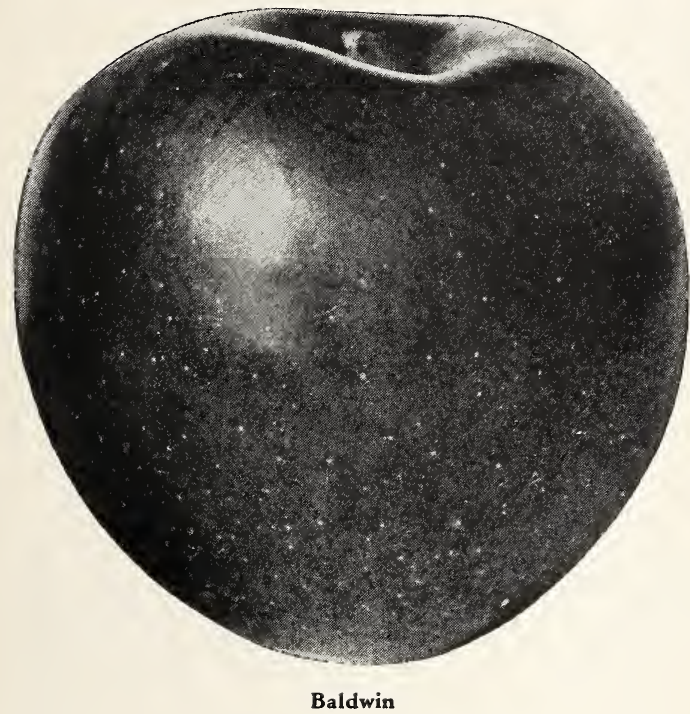

or flat-rounded, depending on the section where grown. In quality it is unsurpassed and incom. parable. In flavor it is sweet, slightly touched with acid, but only enough so to make it all the more pleasing, with an aroma delightfully fragrant. The flesh is fine grained, crisp, juicy, melting, and withal, delicious. People with delicate stomachs, to whom an acid apple is wholly indigestible, can enjoy Delicious without disagreeable after-results. Physicians of note have prescribed it for cases of this character. In keeping quality it ranks with the best, coming out of storage in March and April in perfect condition. In tree, Delicious is tree perfection and one of the strongest, hardiest and most vigorous growers among apples; aphis-resistant and a late bloomer, the hardiest in bud, the best pol. lenizer; blossoms strongly, frost-resistant-a most important and valuable feature. Bears annually.

FALLAWATER (Tulpehocken)-Very large yellowish-green with dull red cheek. Juicy and a good cooking apple. A strong grower and very productive even while young. Season, January to March.

GANO-A red apple. It is very attractive in appearance, stands handling well and is a good shipper. Tree comes into bearing young and is an excellent cropper, bearing regularly and abundantly. December to March.
GOLDEN RUSSET-Medium size and cleargolden russet color. A good apple in colder sections and brings good prices. Keeps till May in a cold cellar, and is then rich and sweet. Tree grows rather willowy; moderate producer. Season, November to April. Origin, Western New York.

GRIMES' GOLDEN-Medium size, golden yellow, tender, rich and slightly sub-acid in flavor. This is a popular early winter apple, commercially successful for fancy box trade. November to April.

HUBBARDSTON-A first-class commercial apple for early winter use. Very productive and bears young. Tree is a vigorous grower and the fruit is large and uniform. Color greenish yellow, nearly covered with bright red splashes. Flesh is fine grained and tender, just sour enough to be good. Season, October to January. Origin, Hubbardston, Mass.

JONATHAN-Medium in size, but of the very finest quality. Valuable for the home garden, but runs a little small as a market apple unless soil is fertile and well tilled. - Tree is not very large and slightly drooping. The fruit is bright red in sun and striped with red. One of the best table apples. Season, November to February. Origin, Woodstock, N. Y.

KING OF TOMPKINS COUNTY - A standard commercial variety. Hard to beat for either table use or cooking. Looks well for market and is just as good as it looks. Fruit bright red, large and uniform. Brings a fancy price over other varieties. Keeps well in cold storage. Flesh is yellow, crisp and juicy; vigorous and a good cropper. Season, October to February. Origin, New Jersey.

MAMMOTH BLACK TWIG (Paragon)-One of the most profitable of all apples. Resembles the Wine Sap, but is a better grower. An excellent keeper.

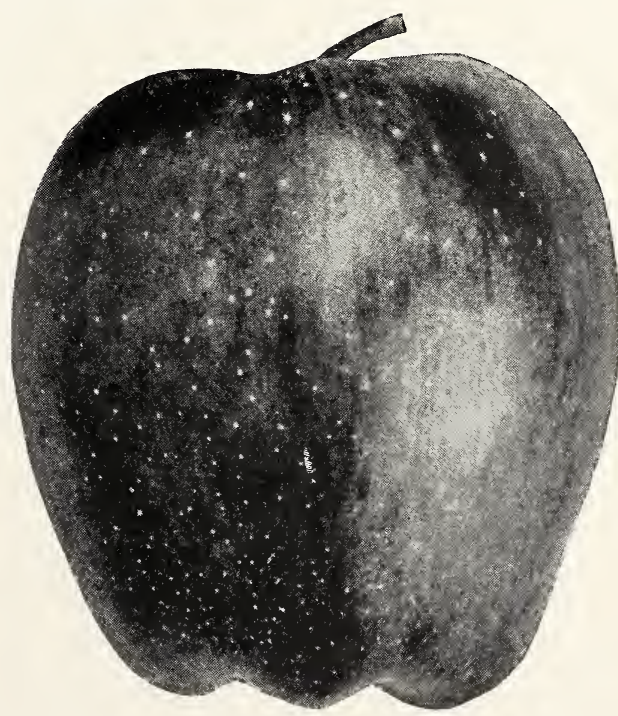

Delicious 


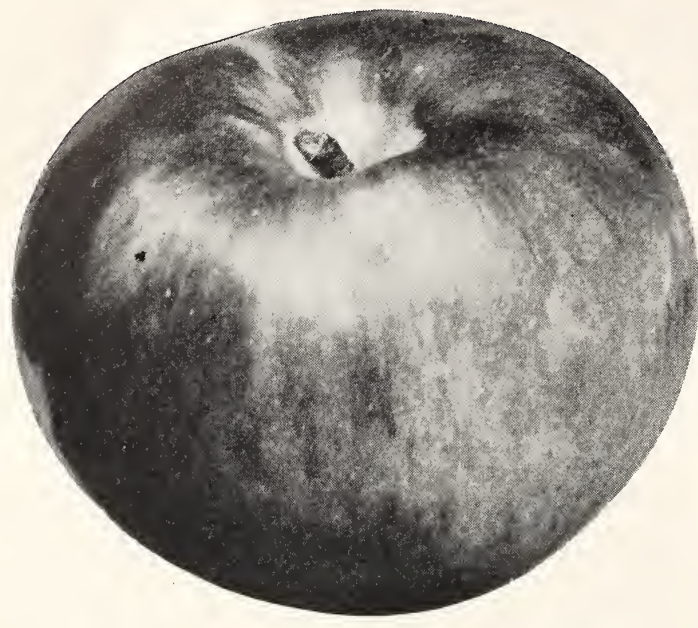

Northern Spy

MANN-Fruit medium to large, roundish oblate, nearly regular; skin deep yellow when fully ripe; flesh yellowish, half fine, half tender, juicy, mild, pleasant, sub-acid. The trees grows straight and symmetrical and makes a large tree in the orchard. It is an early and annual bearer.

McINTOSH RED-A very fine table apple for early winter use. Attractive in appearance, deep red and good size. Flesh is white, crisp, tender, juicy and aromatic. Tree is hardy and comes into bearing young. It requires several pickings, as the fruit ripens unevenly. Season, November to January. Origin, John McIntosh, Dundela, Ont.

NORTHERN SPY-Is one of the leading commercial apples. It ranks among the very best winter apples of New York. The fruit is large and very attractive, bright red color. Always in demand, fine for fancy trade; trees healthy and vigorous. December to March.

NORTHWESTERN GREENING - A greenish yellow apple sometimes faintly marked with red. One of the best winter apples for sections that are too cold for the R. I. Greening. Tree thrifty and very hardy. Fruit large and of good flavor. Season, December to April. Origin, Wisconsin, about 1872 , by E. W. Daniels.

RED CANADA (Old Nonsuch of Mass., Steele's Red Winter) - Medium, oblate, red, tender, crisp, rich, sub-acid, refreshing and delicious. Tree thrifty, but a slender grower. Productive. January to May.

RHODE ISLAND GREENING-An old standby in all apple sections, more widely planted than any other kind, except the Baldwin. One of the best cooking apples and good for table use. Fruit large, green, sometimes with red cheek. Tree is vigorous and a big producer. Origin, Rhode Island.

RUSSET (Roxbury or Boston)-A staple export variety. One of the best shippers and keepers. Medium size, dull green nearly covered with russet. Skin tough, flesh mild and appetizing.
Good in all markets and all apple districts. As hardy as the Greening. Season, January to June. Origin, Massachusetts.

ROME BEAUTY-Has an established reputation in the market and sells at good prices. This apple has a thick skin of smooth yellow or greenish, more or less mottled with bright red. December to May.

SPITZENBURG (Esopus)-One of the finest apples for winter use. Widely planted by early settlers because of its fine flavor. Fruit medium size, conical, nearly covered with bright red. Season, November to February. Origin, Esopus on Hudson River, 1798.

STAYMAN'S WINESAP-This is a good commercial variety for all apple districts outside of New York and New England. Fruit rich dark red, striped with yellow and green. Flesh firm and fine grained. Exceedingly juicy and tasty. This is easily the best of the Winesap group. December to May.

STARK-A profitable winter apple for export. Better than Ben Davis. Good for cooking, poor for eating. Large fruit, dull red color on greenish ground. Keeps till late. Tree is a stout, vigorous grower and very productive. Season, January to May. Origin, Ohio.

TOLMAN SWEET-Tree will grow anywhere that apples can be grown and bears heavy crops. A good variety on which to top-graft more tender varieties. The apple is medium size, light yellow, firm, fine grained and very sweet. Keeps well through the winter. Season, November to April. Origin, Rhode Island, U. S. A.

WAGENER-Is an apple of superior excellence. The color a beautiful bright red with some contrasting pale yellow. It has fine texture, high flavor and excellent quality. It is in season from October to February.

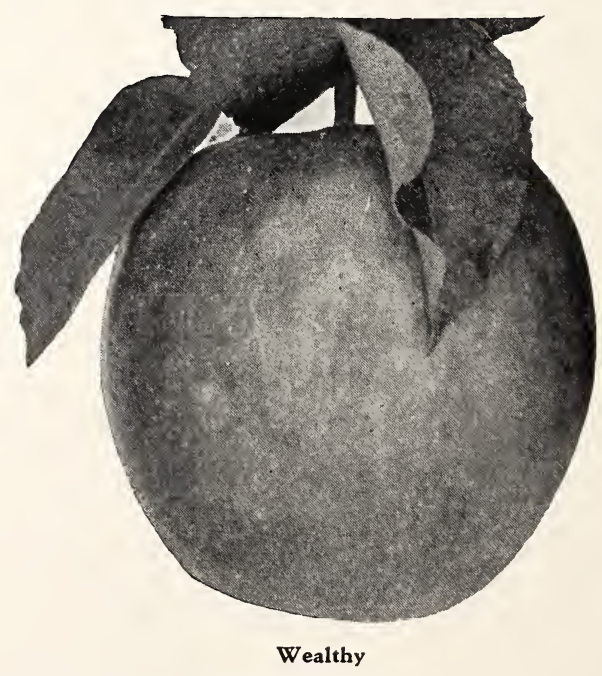

WEALTHY - This variety is particularly valuable for cold climates. It is in season from October to early winter or mid-winter. The crop demands more than one picking. The tree is a good thrifty grower, and a good commercial apple. October to January. 
WINESAP-Medium, dark red, sub-acid, excellent. Tree a moderate grower and abundant bearer. A favorite market variety in the West. December to May.

WINTER BANANA-A comparatively new apple, very flashy in appearance and large in size, deep yellow striped with red; tender and de. licious with distinctive banana perfume and flavor. Good vigorous grower, heavy bearer. November to January.

WOLF RIVER-Tree hardy and productive. Fruit large and handsome, rich red in color, flesh white and of exceedingly fine quality, sub-acid. October to December.

YORK IMPERIAL (Johnson's Fine Winter)-A good shipper and keeper, making it in demand for the export market. Tree is a vigorous grower and a pretty regular bearer. Does best on heavy soils. Not at its best north of Pennsyl. vania. Apple is smooth, blushed and striped with red. Flesh is yellowish, tender and mildly acid. Ready to eat in January and keeps until April or May. Season, January to April. Origin, York County, $\mathrm{Pa}$.

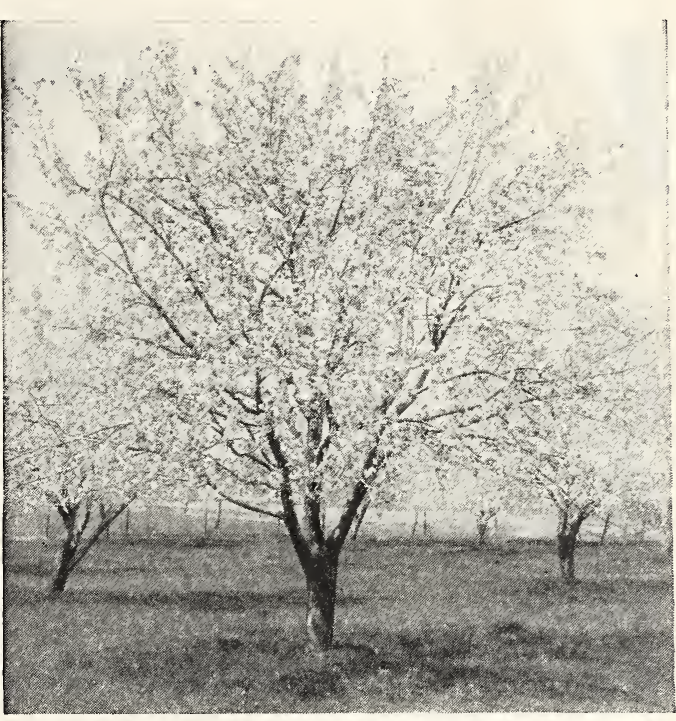

Youthful Apple Trees in a Cloud of Blossoms That Promise Much in the Months to Come

\section{Dwarf Apples}

Standard Apple Trees are propagated by budding or grafting onto roots of French Crab, which produces the tall growing trees. Doucin and Paradise stocks render the tree dwarf in type. The
Paradise stock produces trees which will not grow more than 8 to 10 feet high. On the Doucin stock they may attain a height of 15 to 20 feet, but can be kept lower.

The Leading Varieties of Dwarf Apples are as Follows:

Delicious, Early Harvest, King, McIntosh, Northern Spy, Red Astrachan, Rhode Island Greening, Wagener, Yellow Transparent.

\section{Crab Apples}

$\mathrm{W}$

ITHIN the past few years much attention has been given to improving this class of fruit, because of its adaptability to cold sections, where only a few varieties of apples can be successfully grown. These efforts have been attended with marked success. Crab Apples succeed equally well in all sections, and are valuable for cider, preserving, jelly, ornament, and some of the improved sorts are excellent for eating. Sent to the Eastern markets, they command a very high price.

GEN. GRANT-Is a vigorous grower. Fruit in dense clusters from October to December.

HYSLOP - Fruit large, very brilliantly colored dark red, overspread with thick blue bloom. Tree is a good grower and hardy. October.

MARTHA-Another good variety for all sections. A rapid grower and a great bearer of handsome fruit. Bright, glossy yellow shaded with bright red. Fine tart flavor, surpassing all others for culinary purposes. Season, October and November.
TRANSCENDENT-All things considered, this is one of the most valuable varieties of crab apples grown. Tree remarkably vigorous and immensely productive. Makes a fine market apple. Golden yellow with rich crimson cheek. Good flavor. Season, September and October.

WHITNEY No. 2-Has a smooth, glossy skin, green striped splashed with carmine. Flesh firm, juicy and rich. A great bearer, has no superior. August. 


\section{Standard Pears}

$\mathrm{T}$

HE home orchard is not complete without pears and they are a very profitable com. mercial crop in nearly all parts of the country. Pears will live on a variety of soils, but succeed exceptionally well in a hard clay soil. Tilling and fertilizing are advisable to a certain extent, but should not be carried far enough to produce too vigorous a growth. The quality of the pear is much improved by picking before maturity and by proper ripening indoors.

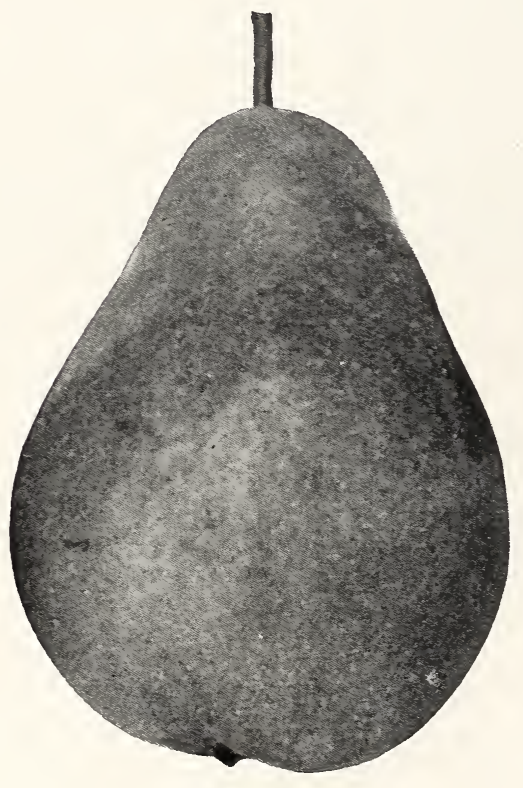

Bartlett

BARTLETT-No pear of the same season equals the Bartlett in flavor, either for eating or canning. Has first place in all markets and brings top prices. Fruit large and yellow, fine grained, buttery and juicy. Sweet, rich flavor. Tree is fairly hardy, grows very rapidly and bears young and heavily. Carefully cultivated and sprayed trees will produce enormous crops of perfect fruit. Season, September.

CLAPP'S FAVORITE-This is a very large, long, yellow pear, tinted with crimson and russet. Flesh is fine grained and white, juicy and ex. ceptionally tasty. Tree is a hardy variety, good grower and producer. It can be planted extensively for commercial purposes; generally about ten days ahead of Bartlett. In September.

WILDER-A valuable early market pear. Regular in form, fair size and very handsome. Greenish yellow color with reddish cheek. Flavor sweet and very pleasant.

\section{Best Summer Varieties}

Bartlett Clapp's Favorite Wilder

\section{Big Profits are Realized from Pear Orchards. Our Trees Produce First Grade Fruit.}

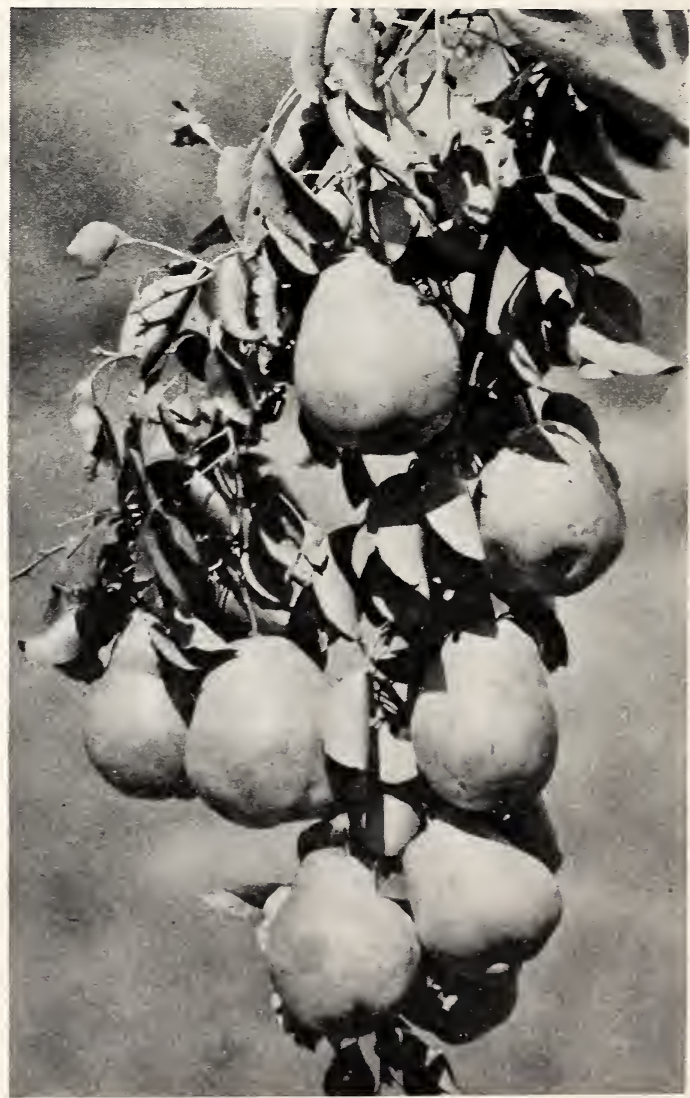

Showing a Branch Bearing Clapp's Favorite Pears 


\section{Best Autumn Varieties}

Anjou, Beurre D'Anjou

Beurre Clairgeau

Beurre Bosc

Duchesse D'Angouleme

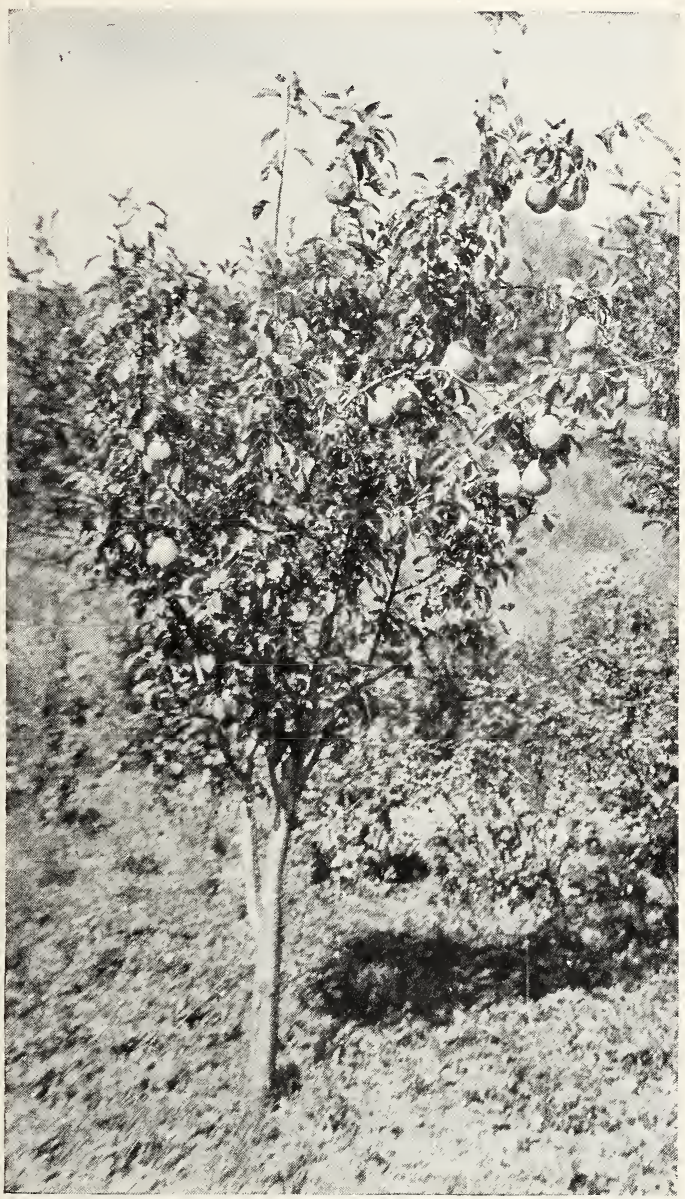

Duchess 2-Year Pear

ANJOU, BEURRE D'ANJOU-Large greenish. yellow fruit tinged with dull red and russet, flesh white, buttery, fine grained and richly flavored. Looks and keeps well until mid-winter. Tree is straight and vigorous grower, long lived and productive. October.

BEURRE CLAIRGEAU-Its large size and beautiful cheek, its excellent shipping and keeping qualities, all combine to make this a profitable variety. Tree is first class in vigor, hardiness and productiveness. Succeeds either as dwarf or standard and bears a long time, always sweet and juicy. Season, October and November.

BEURRE BOSC-A large russety pear with long neck; melting, high flavored and delicious. Bears well. September to October.

\author{
Flemish Beauty \\ Kieffer \\ Seckel
}

Sheldon

Vermont Beauty

Worden Seckel

DUCHESSE D'ANGOULEME - For years this pear has been counted among the best and most profitable varieties, especially grown on quince stock. Excellent for export, cold storage, and for every use to which a pear can be put. Strong grower, productive, not subject to blight. Fruit large, light green patched with russet, melting, juicy, sweet and good. October and November. Origin, Angers, France, 1812, chance seedling.

FLEMISH BEAUTY-Where this variety succeeds well it is a most popular pear. In some sec. tions it has of late been subject to scab and cracking of the fruit. Large size, light yellow when ripe, with patches of brownish-red; rich, sugary flavor. Tree is first class in hardiness, productiveness and early bearing. Season, September and October.

KIEFFER-There is perhaps no pear about which a greater diversity of opinion exists. Tree beats everything for hardiness and cropping. Fruit always large, uniform, golden yellow with bright cheek, very fine; flavor moderately sweet. A valuable pear for canning. Will grow almost anywhere. Season, October to January.

SECKEL-One of the richest and finest varieties known; small, yellowish russet with red cheek. Flesh whitish and buttery, very juicy. Septem. ber.

SHELDON-One of the most delicious eating pears. Should be in every home garden. Tree is vigorous, erect, second rate in productiveness and last to come into bearing. Fruit large, creamy, sweet and aromatic. Thorough fertilizing and cultivation will aid in making this a profitable variety. Season, October and November.

VERMONT BEAUTY-A most desirable pear. The fruit is of medium size, very handsome, being yellow with a bright carmine cheek. The flesh is rich, juicy, aromatic, of the best, and almost equal to the Seckel; ripens immediately after the Seckel.

WORDEN SECKEL-Originated in Oswego County, N. Y. It is a seedling of the Seckel, and is equally as good in quality as that variety and more juicy, with an aroma equally as rich and inviting, while in size, color, form and appearance it is decidedly superior. The color is yel. low, with light red on the sunny side. The tree is very hardy and an enormous bearer, and the fruit is ripe just after the Seckel. All lovers of good pears should have trees of this variety.

Note-DWARF PEARS can be supplied in the following varieties: Bartlett, Clapp's Favorite, Beurre D'Anjou, Duchesse D'Angouleme, Flemish Beauty, Kieffer, Seckel, Worden Seckel. 


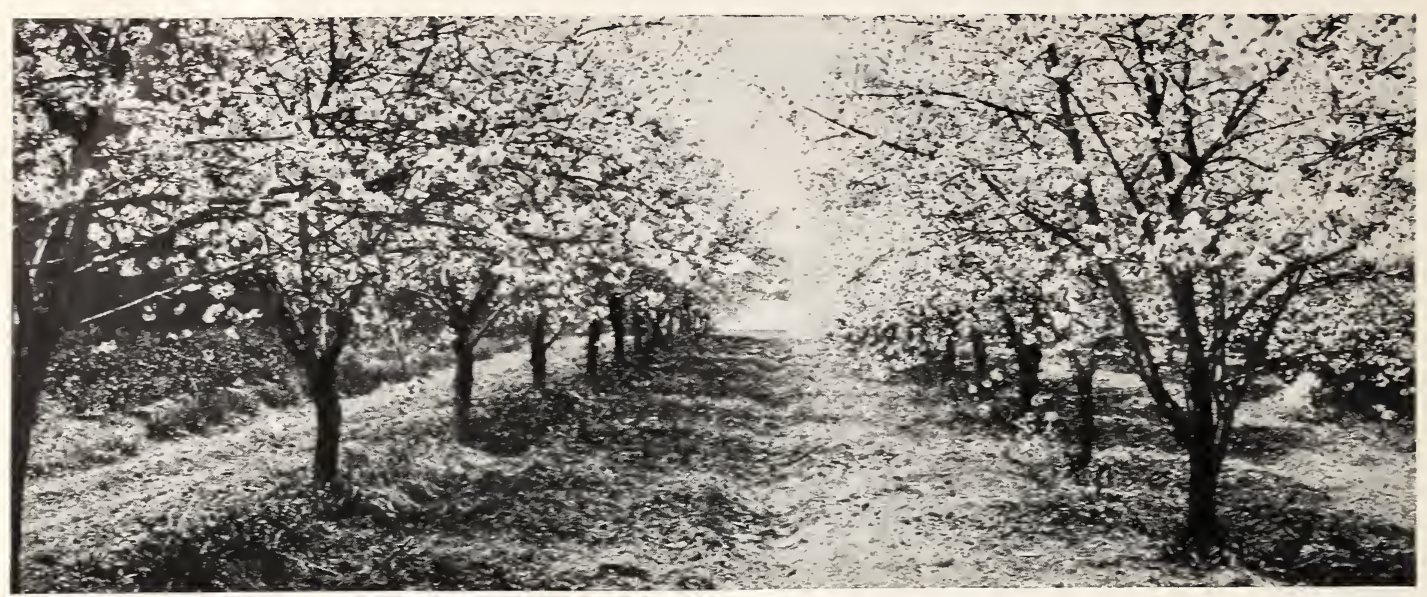

A Young Cherry Orchard in Bloom

\section{Cherries}

$\mathrm{T}$

HE cherry succeeds well on dry soils, will thrive and bear with almost no care, but will respond to good treatment, until they are well grown at least. While no fruit is more liked by members of the family than this delightful fruit, they offer great possibilities as a commercial proposition. Cherries are divided into two classes, sweet and sour; sweets being called Hearts and Bigarreaus, the sours Dukes and Morellos. The sweets attain a larger size than the sours, but are not as hardy and are more likely to be injured by bursting of the bark.

\section{Heart and Bigarreau Varieties - Sweet}

\author{
Black Tartarian \\ Bing \\ Governor Wood
}

Napoleon

Schmidt's
Windsor

Yellow Spanish
BLACK TARTARIAN-Is widely known as the favorite dooryard and roadside sweet cherry. It has a very sweet, rich flavor and is earlier than most sweet cherries, bearing in June. Excellent quality.

BING-One of the largest of the black sweet cherries. Flesh firm, but juicy. A good shipper, exceptionally successful in the Pacific Northwest, enjoying good success in the Central and Eastern sections also. Tree is vigorous, upright grower and producer. July.

GOVERNOR WOOD-Very large, rich; light yel. low, with red cheek; juicy and sweet. One of the very best. Last of June.

NAPOLEON BIGARREAU - Leads in the firm fleshed sweet class. It takes its place by virtue of the large size, handsome appearance, and high quality of the fruit. The flavor is rich and sweet, which with the abundant juice and firm, crackling flesh, makes this a most delicious and refreshing cherry for dessert. Tree is an upright grower and a heavy bearer, recommended generally for commercial purposes. June.

SCHMIDT'S BIGARREAU-A most promising cherry; fruit of immense size, of rich, deep black; flesh dark, tender, very juicy, with a fine flavor; bears abundantly and makes a toothsome dish for the table.

WINDSOR-A seedling originated at Windsor, Canada, and a fine variety, too. Fruit large, liver-colored, flesh remarkably firm and of good quality. A very valuable late variety for market and for family use. Middle of July.

YELLOW SPANISH - Bears abundantly and regularly and comes into bearing young with the crop well distributed. For centuries Yellow Spanish has led as the best variety of all the Bigarreaus. Fruit matures in July. 


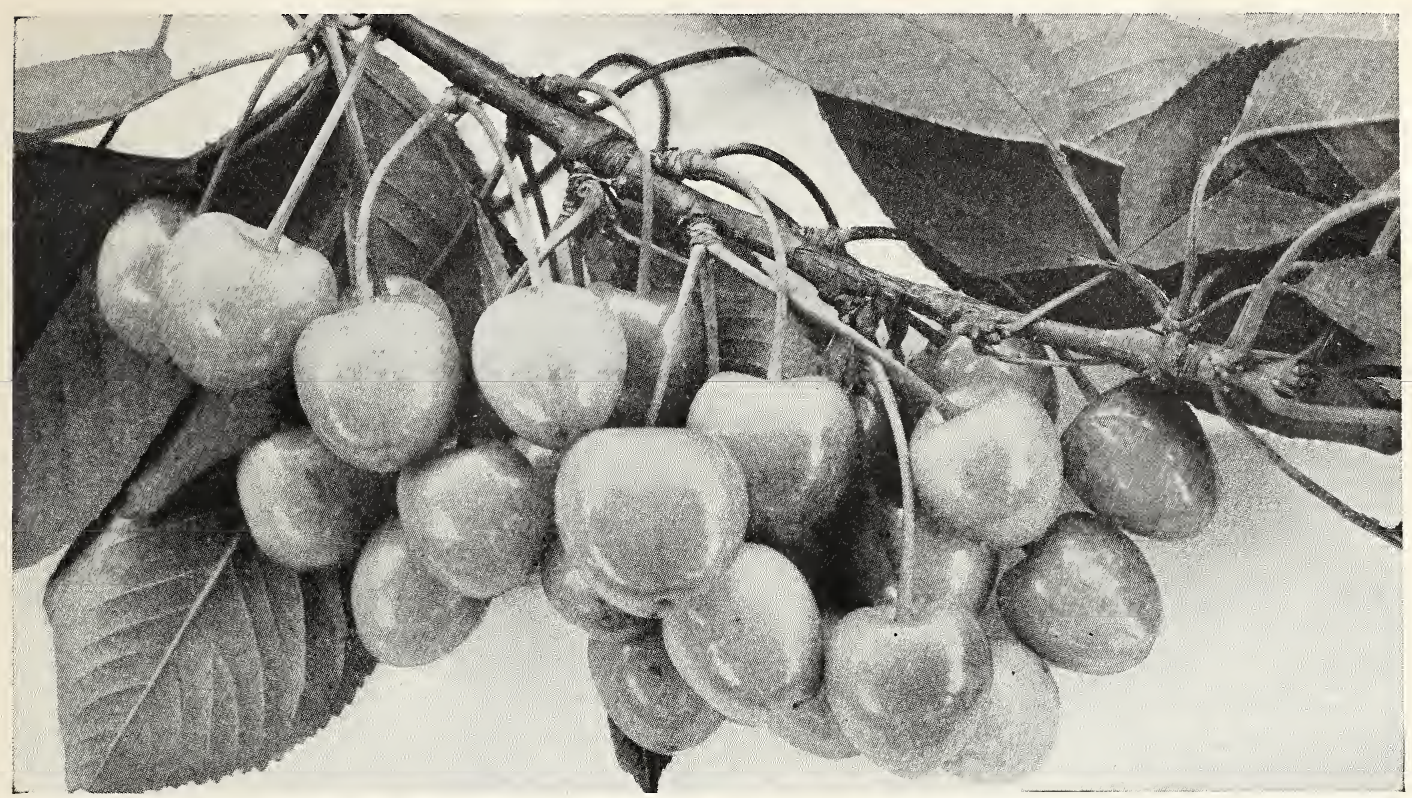

Napoleon Bigarreau or Royal Ann

\section{Duke and Morello Varieties-Sour}

\section{Dyehouse \\ Early Richmond \\ English Morello \\ May Duke}

DYEHOUSE-One of the best sour cherries for market or home use. It is larger, finer, of better quality and has a smaller pit than Early Richmond. The tree is hardy, is an upright grower and always productive. The great quality of this variety is its tendency to hang on the tree after it is ripe.

EARLY RICHMOND-One of the most popular of all the acid cherries. Cannot be surpassed for hardiness or for cooking purposes. Fruit

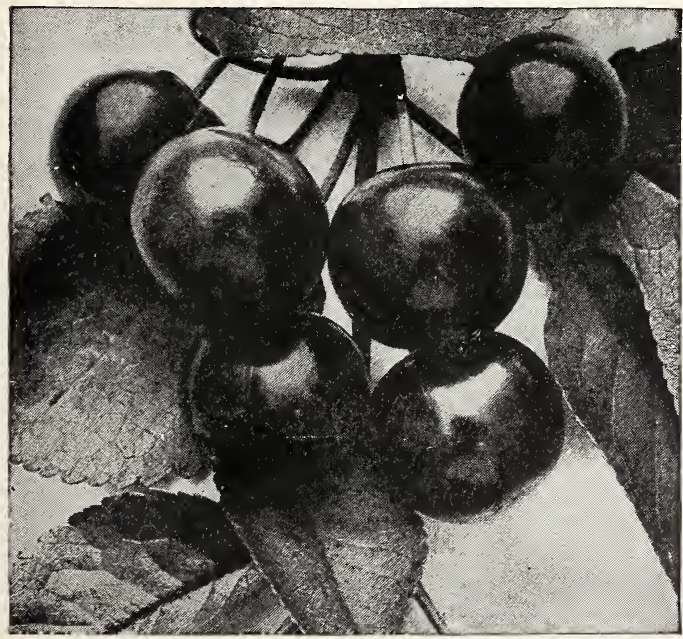

Black Tartarian

\section{Montmorency}

Olivet

is of medium size, round and dark red. wonderful bearer. Ripens in June.

ENGLISH MORELLO-Medium sized cherry of a very dark red color, sometimes nearly black. It is very acid in flavor, the flesh is of good quality and it makes a fine canner. Tree is a small grower with light limbs and trunk. Ripens in July.

MAY DUKE-Large, red, juicy and rich; an old excellent variety; vigorous and productive. Middle of June.

MONTMORENCY - Best of all sour varieties and enjoys a greater demand. Trees are clean grow. ers and are less subject to disease, less affected by wet weather and are the most productive bearers of all sour cherry varieties. Montmorency can always be depended upon for a full crop regardless of unfavorable season. It is attractive, brings a good price and is a fine shipper. Always in demand at the canning factories. Fruit is of good size and fine flavor and a bright, clear, shining red in color. Flesh of fine quality and sub-acid. Ripens ten days after Early Richmond.

OLIVET-A new Duke of French origin. Unlike most others of this class, it is said to be very early and to ripen over a long period. Fruit very large, globular, and of a deep, shining red.

OSTHEIME-Known as the Russian Cherry, as it was imported from that country. Thoroughly tested and found hardy. Fruit is large and roundish. Flesh, liver-colored, tender, juicy and almost sweet. Fine quality. Ripens in July. 


\section{Peaches}

THE most universally planted fruit for home use. Peach trees are being planted profitably as fillers in apple orchards, for they make ground space, that is practically idle, pay well until the apples come into bearing. Peach trees will thrive wherever corn or potatoes can be raised. In planting, prune the tops to a clean whip, and each succeeding year prune the shoots of last year's growth.

\section{Best Peach Trees to Plant}

\begin{abstract}
Belle of Georgia
Carman

Chair's Choice

Champion

Crawford's Early

Crawford's Late
\end{abstract}

\author{
Crosby \\ Elberta \\ Fitzgerald \\ Greensboro \\ Hale
}

BELLE OF GEORGIA-Elicits praise from all who know it because of the great beauty of its fruits. At its best, it is one of the glories of the peach orchard, the fruits being large, creamywhite with a beautiful crimson cheek. Is an ex. cellent shipper. Freestone. First of September.

CARMAN-A general favorite in nearly every peach region on this continent. There is much merit in the fruits, especially for a peach ripening so early. It is a brilliant red. Freestone. August.

CHAIR'S CHOICE-Fruit matures in late midseason. Color, pale green dotted with reddish. green, is very attractive and is considered a select fruit; is quite large. October. Freestone.

CHAMPION-This is the best of the white freestone varieties. Skin creamy-white with red flush. This is also a desirable variety for commercial orchards. It is extremely hardy and of uniform good quality. Late August. Freestone.

CRAWFORD'S EARLY-This peach has all of the characters that gratify the taste. Besides being one of the very best in quality, it is one of the handsomest peaches. Color, rich red splashed and mottled with darker red and golden yellow. The flesh is beautiful and perfectly free from the stone. Matures in mid-season. Tree is vigorous and productive. First of September. Freestone.

CRAWFORD'S LATE-Fruit is unsurpassed in appearance and scarcely equalled in texture of flesh and richness of flavor. Its color, sof t tints of red and yellow. Fruit matures late. Used extensively in commercial orchards. Last of September. Freestone.

CROSBY-A peach of good quality which was once extensively planted. Requires intensive cultivation to reach good marketable size. At its best the fruit is first class in every respect. Fine grained, tender, sweet and very agreeable. Freestone. Tree is vigorous, healthy, fairly hardy and very productive. Ripens September. Origin, Massachusetts, 1876.

ELBERTA-The best peach of its season for all markets, as it has grand shipping qualities. Probably the greatest commercial peach on the market today. The fruit is large, yellow with red cheek, juicy and highly flavored. Flesh is

\author{
Heath Cling \\ Mountain Rose \\ Niagara \\ Rochester \\ Salway
}

\section{Smock \\ Triumph \\ Wonderful \\ Wheatland \\ Yellow St. John}

yellow and fine. Pit perfectly free. Tree is vigorous, hardy and a good uniform cropper. Ripens about ten days later than Early Craw. ford, late September. Origin, Georgia; cross between Chinese Cling and Early Crawford. Freestone.

FITZGERALD-This is one of the hardiest varieties of peaches, and the quality resembles Early Crawford. Fruit runs medium to large, has yellow flesh. Freestone. Extra hardy, succeeding in Canada and in Michigan perfectly. Origin in the garden of Mr. Fitzgerald, Oakville, Ont., about 1895. September.

GREENSBORO - A valuable early variety not easily subject to rot, extra large, very early. Tree is extremely hardy and is therefore recommended for sections where difficulties are experienced with other varieties. Late July. Freestone.

HALE-This is a new peach combining the most desirable qualities of the other varieties. Brilliantly colored with deep golden yellow. Middle of August. Freestone.

HEATH CLING (White Heath Cling)-Originated in Maryland, where it is much esteemed. Of large size and good flavor. September.

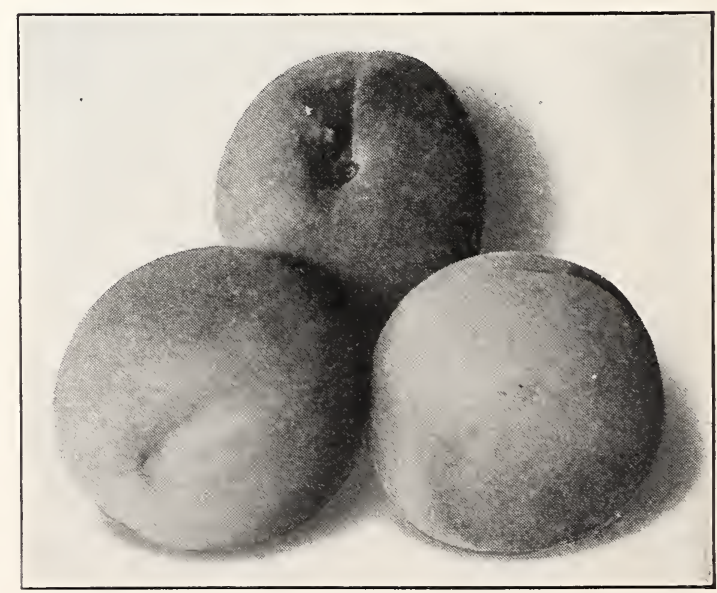

Hale Peach 


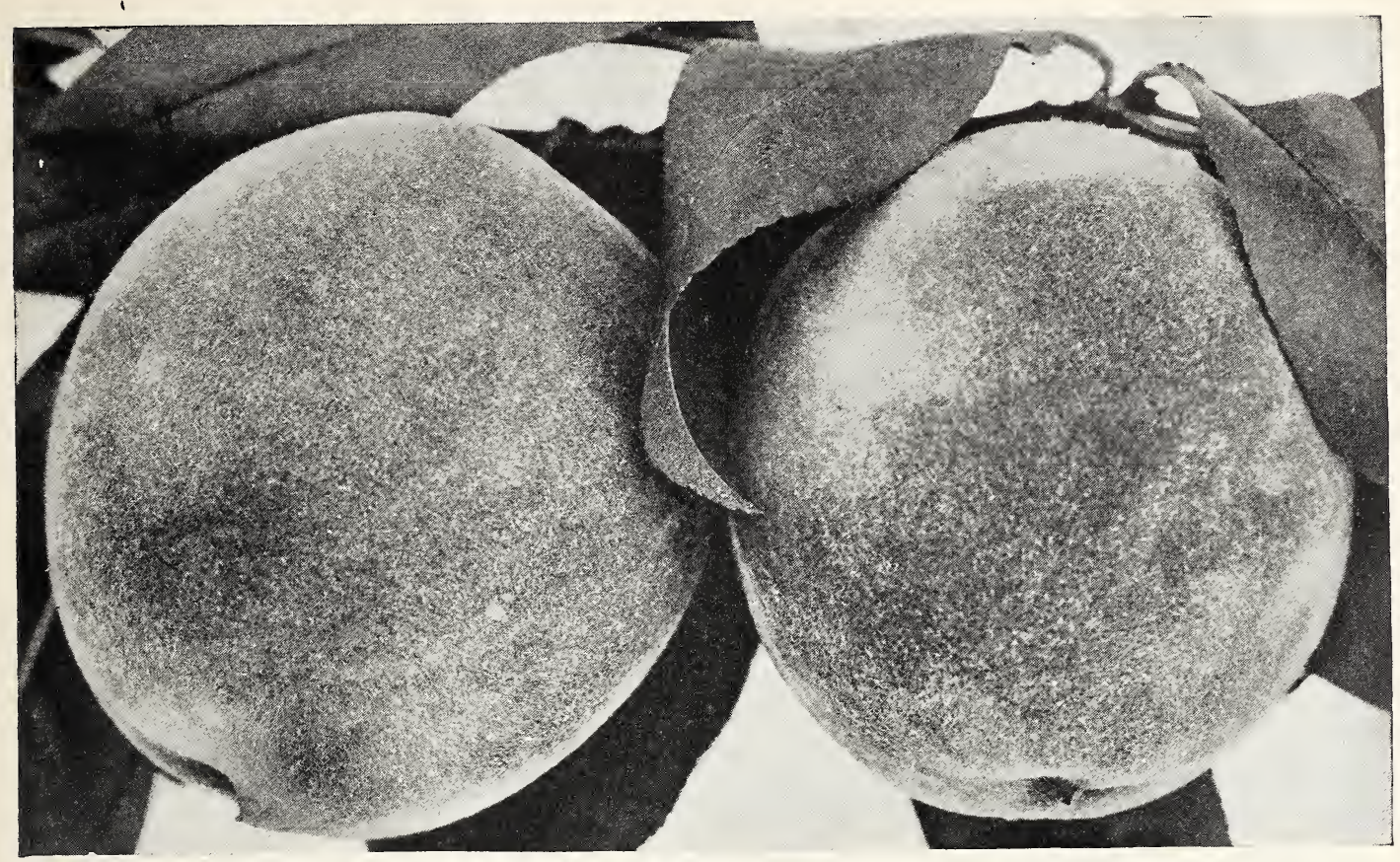

Rochester

MOUNTAIN ROSE-A favorite in New Jersey where it ripens early and grows to large size for so early a peach. A reliable cropper. Color white with carmine cheek, inside creamy white, abounding in rich, sweet juice. Early August. Origin, New Jersey. Freestone.

NIAGARA-A very large, yellow peach and a very popular one, especially in Niagara County, N. Y., where it originated. Bears a very close resemblance to Elberta, but is larger and finer in every way and ripens one week earlier than Elberta. The fruit is delicate in flavor and luscious. Tree is vigorous, healthy, being seldom affected with leaf curl, and a productive, regular bearer. Season, September first. Freestone.

ROCHESTER-Has the habits and characteristics of the Crawford, but fully two weeks earlier. Yellow, freestone, good size, very sweet and fine flavor. Requires only half the usual amount of sugar for canning. Does not rot on the trees. Since its introduction this splendid variety has brought each season from 20 c to 30 c a basket more than the prevailing market price. In a class by itself. Stock limited.

SALWAY - A yellow fleshed freestone peach of attractive appearance and of good quality; considered one of the best sorts for canning, preserving and evaporating. The trees are hardy, healthy and very productive. Fruit matures very late. October. Freestone.
SMOCK-A first-class late market peach. Ripens in early October and is considered first quality for canning or evaporating. Not sweet for eating, but has a distinctive, agreeable flavor. Large, yellow, orange red cheek; freestone. Origin, New Jersey.

TRIUMPH-An extra early yellow fleshed peach. Tree medium size; skin very tender; juicy and sweet. July. Freestone.

WONDERFUL-A variety noted for the great size and beauty of its fruit. Has a rich golden color nearly covered with bright crimson which shows up well in the basket. The flesh is yellow, firm and highly flavored. First grade for market and for eating and cooking. This variety has a very small freestone pit and ripens near the middle of October. Origin, United States. Freestone.

WHEATLAND-Originated with D. S. Rogers, near Rochester, N. Y. Mr. Rogers, who has large orchards, including the leading sorts, thinks this is the finest of all. Fruit large; color golden yellow, with crimson tint; flesh firm and of finest quality. Ripens between Crawford's Early and Late. Freestone.

YELLOW ST. JOHN-This peach has maintained great popularity for home orchards and in many peach regions is grown for the markets. Fruit matures early. Color, deep yellow, blushed and splashed with carmine. Middle of August. Freestone. 


\section{Plums}

7 HE plum does best on a clay soil, dry and well drained. It grows the most thriftily and with cultivation suffers least from "Curculio" or "Black Knot." There is little trouble in keeping the trees from insects and disease. After the blossoms have fallen spread a sheet on the ground under the tree. Then jar the tree so as to shake down the stung fruit and insects. These should be burned. This should be done every day for a week or more and it is important that it be done early in the morning.

\section{Best European Sorts}

Beauty of Naples

Bradshaw

Coe's Golden Drop

Fellemberg

\section{German Prune Green Gage \\ Imperial Gage Lombard}

Monarch

Moore's Arctic

Niagara

Pond's Seedling
Reine Claude

Shipper's Pride

Shropshire Damson

Yellow Egg

BEAUTY OF NAPLES-A new variety of the highest promise; size large, color greenish yellow, flesh firm, juicy and very fine flavored; tree very hardy and prolific. Middle of September.

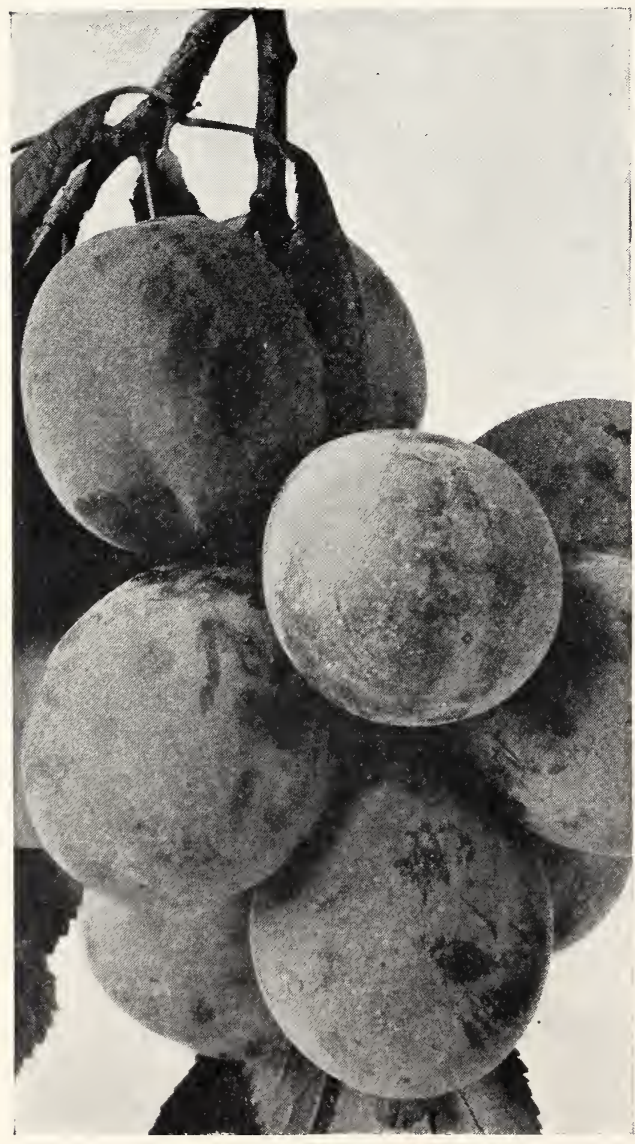

Lombard Plum

Medium large; dark violet-red; flesh yellow, juicy and pleasant flavor; popular, hardy, valuable commercially
BRADSHAW-Leads all other plums in number of trees, according to a survey of the leading orchards. The trees grow large and well formed, bear regularly and heavily. The plums are large, attractive in appearance, being a light purplish red changing to dark reddish at ma. turity, which occurs in July.

COE'S GOLDEN DROP-Large and handsome, oval; light yellow; flesh firm, rich and sweet; adheres to stone. Last of September.

FELLEMBERG (French or Italian Prune)-Large, oval; purple; juicy and delicious; parts from the stone; fine for drying. September.

GERMAN PRUNE-Large, dark blue, showing a dense bloom when ripe; rich and agreeable flavor; well thought of for drying, and therefore, commercially desirable. September.

GREEN GAGE-Small; considered the standard of excellence; slow grower. Middle of August.

IMPERIAL GAGE-Large; oval; greenish; juicy, rich and delicious; parts from the stone. Very productive and one of the best. Middle of August.

LOMBARD-Probably the most widely planted in America, medium size, violet-red in color, hardy and productive, having a good market value. August.

MONARCH-Very large, roundish oval; dark purplish blue; freestone; excellent. An abundant bearer. October.

MOORE'S ARCTIC-Size medium or below; skin purplish black, with a thin blue bloom; flesh greenish yellow, juicy, sweet and pleasant flavor. Charles Downing speaks of it as follows: "A new, hardy plum, which originated in the highlands of Aroostook County, Maine." August.

NIAGARA-A vigorous, productive variety; valuable both for dessert and cooking; fruit large and handsome, remaining well on the tree; flesh juicy, rich and fine flavored. Last of August.

POND'S SEEDLING - Is pre-eminent among plums for its large size. It is distinguished also by its form and color, both being pleasing as well as distinctive. This fruit ripens late in season and is a purplish-red in color. September. 
REINE CLAUDE-For the qualities that gratify the sense of taste, richness of flavor, consistency and texture of flesh, the Reine Claude is unsurpassed. The trees are very productive and bear regularly. Fruit ripens in July and is of yellowish-green.

SHIPPER'S PRIDE-The fruit is of large size, it being no uncommon occurrence to find specimens measuring two inches in diameter each way, as it is nearly round; it is what Mr. Charles Downing calls a semi-cling, of a handsome, dark purple color; excellent for canning and a good shipper. September.

SHROPSHIRE DAMSON-Is the best known of the Damsons, being found not only in nearly all commercial plantations but in the smallest home collections as well. Shropshire is enormously productive, bearing its load of fruit year after year. It is a standard among fruits for productivity and reliability in bearing, which is late in season. October.

YELLOW EGG-Large, golden-yellow egg-shaped fruit, sweet and mild in flavor; flesh somewhat coarse, but excellent for cooking purposes. September.

\section{Best Japan Sorts}

Abundance Burbank
Red June Wickson
ABUNDANCE - Large and beautiful; amber, turning to a rich, bright cherry; flesh light yellow, juicy, tender, sweet, exceedingly productive. Season, very early.

BURBANK-Large and beautiful; clear cherry red; an abundant bearer; valuable market variety. Ripens early in September.

OCTOBER PURPLE-One of Luther Burbank's Hybrids and considered by him one of his best. Large, purple, yellow flesh; very late.

RED JUNE-A consensus of the opinions of those who have had actual experience with the variety shows that it closely follows Abundance and Burbank in popularity. The color is a mottled garnet-red overlaid with thin but very distinct and delicate bloom. Ripens early in July.

WICKSON-The largest of the oriental plums, if not the largest of all plums. Its handsome color of red and distinct form make it very attractive, bearing in September.

\section{All varieties of plums, especially Japan sorts, make handsome ornamental trees as well as being rich in fruit.}

\section{Quinces}

J NDER proper conditions and good culture, the quince tree bears heavily and regularly and is a highly profitable crop, since the market is never fully supplied. The tree is easily transplanted and does well on any good soil.

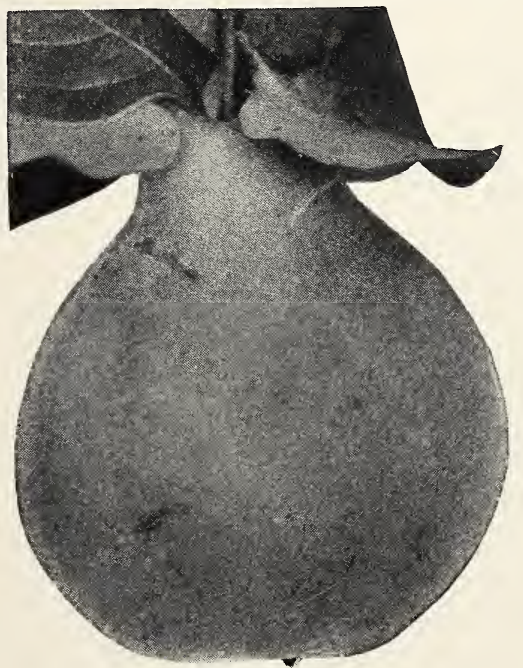

Orange Quince
CHAMPION-Will bear more quickly than any other variety. Trees in the nursery row of ten bear when two years old. The fruit is large and handsome. Flesh cooks as tender as an apple and without hard spots or cores. Very fine for preserves, jellies, marmalades, etc. The tree is vigorous, hardy and very productive. Ripens in November.

MEECH'S PROLIFIC - Ripens earliest of all quinces. Quality unsurpassed and quince itself is very large, of a yellowish color.

ORANGE-This fruit, of a bright golden yellow, is considered one of the best for its quality. Ripens in October.

REA'S MAMMOTH-Like all quinces is a bright yellow; ripens early and its fruit is very large. 


\section{Grapes}

\section{The Best Varieties of Grapes}

\author{
Agawam \\ Brighton \\ Caco \\ Campbell's Early
}

\author{
Catawba \\ Concord \\ Delaware \\ Green Mountain
}

\author{
Moore's Diamond \\ Moore's Early \\ Niagara
}

Salem

Wilder

Worden

AGAWAM (Rogers' No. 15)-One of the best of the red varieties; bunch variable in size; flesh tender and juicy. A good grower and bearer. August.

BRIGHTON-This is an almost seedless variety of good quality; clusters are exceptionally large; reddish-blue in color; vines are hardy. Late August.

CACO-A new red variety of extremely rich flavor. It is a cross between the Catawba and Concord, with all the good qualities of both. Ripens early.

CAMPBELL'S EARLY-Clusters large and handsome; berries large, nearly round, black, with light purple bloom; flesh rather firm, but tender; quality rich, sweet, slightly vinous; a strong and vigorous grower; very early; the berries do not drop easily from the clusters, and the fruit keeps a long time in perfection. Last of August.

CATAWBA-Bunches large and loose, berries large, of coppery red color, becoming purplish when well ripened; vinous, rich; requires the most favored soils and situations, good culture and warm seasons to mature perfectly in West. ern New York.

CONCORD - Large, good quality, early grape; exceptionally hardy and thrives in any grape belt. Blue-black berries of large size. Widely known and well accepted as a market variety. Very productive and reliable. Middle of September.

DELAWARE-Small bunches and small berries; juicy and sweet; a highly satisfactory table grape; skin is thin and light red in color. Vine grows freely and is perfectly hardy. Early Sep. tember.

GREEN MOUNTAIN (Winchell)-A very early and delicious grape; pulp tender and sweet, with but one or two seeds; bears young and profuse$1 y$, and ripens from the 25th of August to the lst of September. The only grape thus far tested that ranks first, both in earliness and quality.

MOORE'S DIAMOND - Leading early white grape with yellowish tinge; bunches large, very few seeds; juicy and free from pulp. Vine vig. orous in growth, bears early September.

MOORE'S EARLY-A large, purplish-black berry; sweet and of good quality, ripening about ten days earlier than Concord. Vine vigorous and hardy.

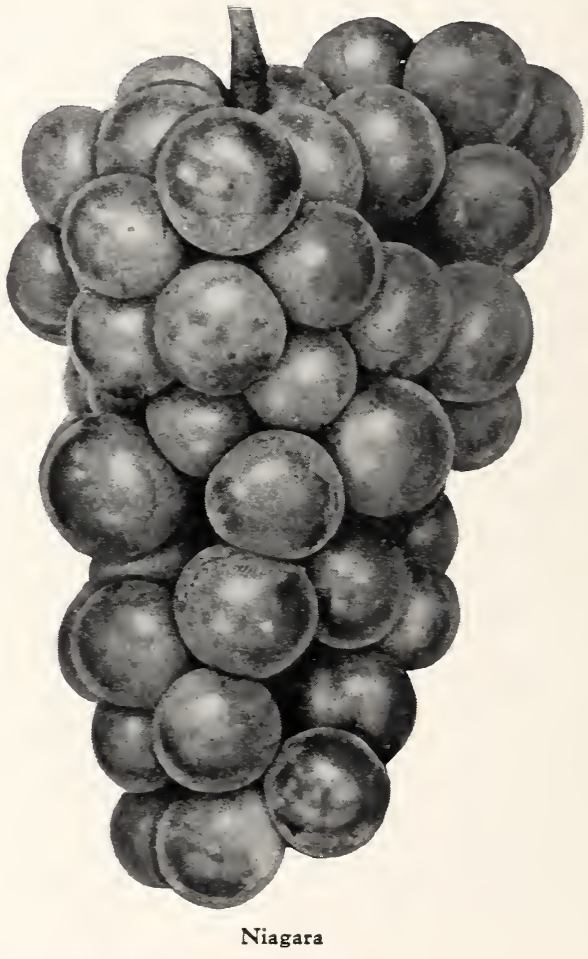

NIAGARA-Bunch medium to large, compact, occasionally shouldered; berry large, roundish, uniform; skin thin but tough, pale green, changing to pale yellow, with a thin whitish bloom; flesh slightly pulpy, tender, sweet. Remarkably vigorous, healthy and productive; foliage thick and leathery. Ripens with the Concord. Most valuable white grape in eultivation.

SALEM-Coppery red berries, large; flesh juicy and of fine quality. Very productive. This grape also ripens in September.

WILDER (Rogers' No. 4)-Large and black; bunches generally shouldered; berry round and large; flesh buttery, with a somewhat fibrous center; sweet, rather sprightly; ten days earlier than the Isabella.

WORDEN-A seedling of the Concord. Bunch large, compact, handsome; berries large-larger than those of the Concord. It ripens a few days earlier, and is superior to it in flavor. Very popular for the vineyard and garden. 


\section{Apricots}

$\mathrm{T}$ $\mathrm{HE}$ apricot has a distinct flavor and is one of the best of market fruits. The trees bear young and most profusely. It is a most welcome fruit, ripening between the cherry and the peach.

ALEXANDER-A large, oblong, orange yellow fruit, spotted with red. Flesh is sweet, juicy and very good. It is a hardy, prolific bearer and very popular in the East. One of the best of the Russian varieties. Ripens early.

EARLY GOLDEN-An American variety of apricot. Fruit is small, pale orange, juicy and sweet. The tree is hardy and prolific. Ripens first of July.

MONTGAMET -A pale yellow apricot slightly tinged with red; flesh is firm, juicy and agreeably acid. Middle of July.

MOORPARK-The largest of fall apricots; orange in color with a red cheek. More money is made from these than from any other variety. Flesh is firm, juicy and very fine. Moorpark ripens in August.

\section{Nectarines}

A delicious, smooth skinned fruit resembling the peach. Flesh is rich, melting and juicy. A beautiful and desirable fruit.

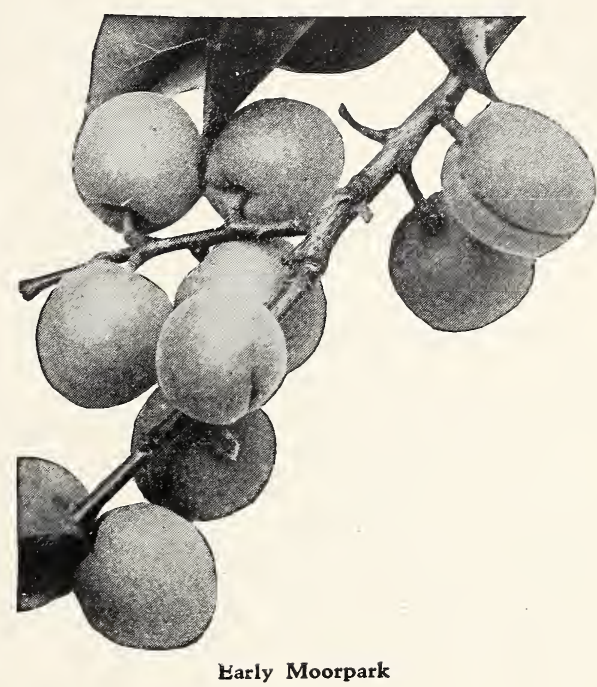

VICTORIA-Very large and handsome, deep yellow, with a bright blush, and mottles of red; flesh yellow to the stone, sweet with a pleasant and peculiar flavor. Freestone.

EARLY VIOLET-Medium size; yellowish green, nearly covered with dark purplish red; juicy, rich and highly flavored. Last of August.

\section{Asparagus}

BARR'S MAMMOTH

(Barr's Philadelphia Mammoth) - Origi . nated with Crawford Barr, a prominent market gardener of Pennsylvania. It is one of the earliest varieties, very productive and grows to the largest size.

\section{CONOVER'S COLOS.}

SAL - Immense size, remarkably tender and high flavored, vigorous grower, sending up from fifteen to twenty sprouts each year; color deep green and crown

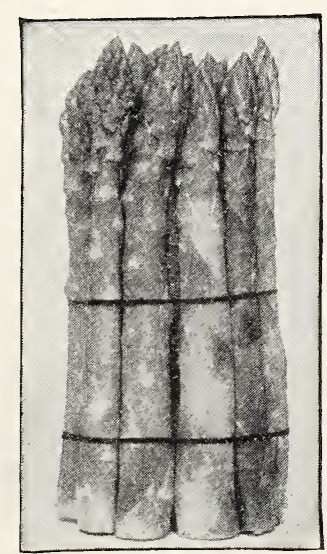

Palmetto very close. Can be cut one year sooner than the other varieties.

PALMETTO-Until recently we believed that the Conover's Colossal was the best sort known, but we are now forced to concede that the $\mathrm{Pal}$. metto is earlier and a better yielder, and more even and better in growth, and it will eventually supersede the old favorite. The average bunches contain fifteen shoots, measuring $13 \frac{1}{2}$ inches in circumference and weighing nearly two pounds. It has been tested both North and South and has proved entirely successful in every instance.

PEDIGREED WASHINGTON-A new rust-resisting variety produced by the U. S. Dept. of Agriculture. Nearer to being rust-proof than any other sort. This is fast taking the place of all other varieties. 


\section{Raspberries}

UR raspberries have been inspected by the Department of Agriculture, State of New York, and found to be free from injurious diseases, infecting the raspberry, commonly known as Mosaic, leaf-curl and rosette (or Eastern blue stem), which have been found widely distributed in New York and other states. Raspberries succeed best in a rich, mellow soil. They should be planted four feet apart in rows five or six feet apart. They are easily cultivated, only requiring manuring and cutting out of dead wood and suckers. Old canes should be removed after bearing season is over. If the location is much exposed, plants may be protected from severe cold by raising the earth between the hills into a bank or mound. Then bend down the plants to meet, fasten them and cover them with earth or coarse litter. In the spring uncover and tie to stakes.

\section{Black Raspberries}

BLACK DIAMOND-A leading variety for market and home use, ripens early, fine flavor and a good shipper. For drying and evaporating it excels all others.

CUMBERLAND_An early season, high quality berry; largest of all the black raspberries; possesses shipping qualities as good as any; a good variety for the market. Mid-season.

GREGG-Large, black raspberry of good quality. A hardy, vigorous grower and prolific bearer.

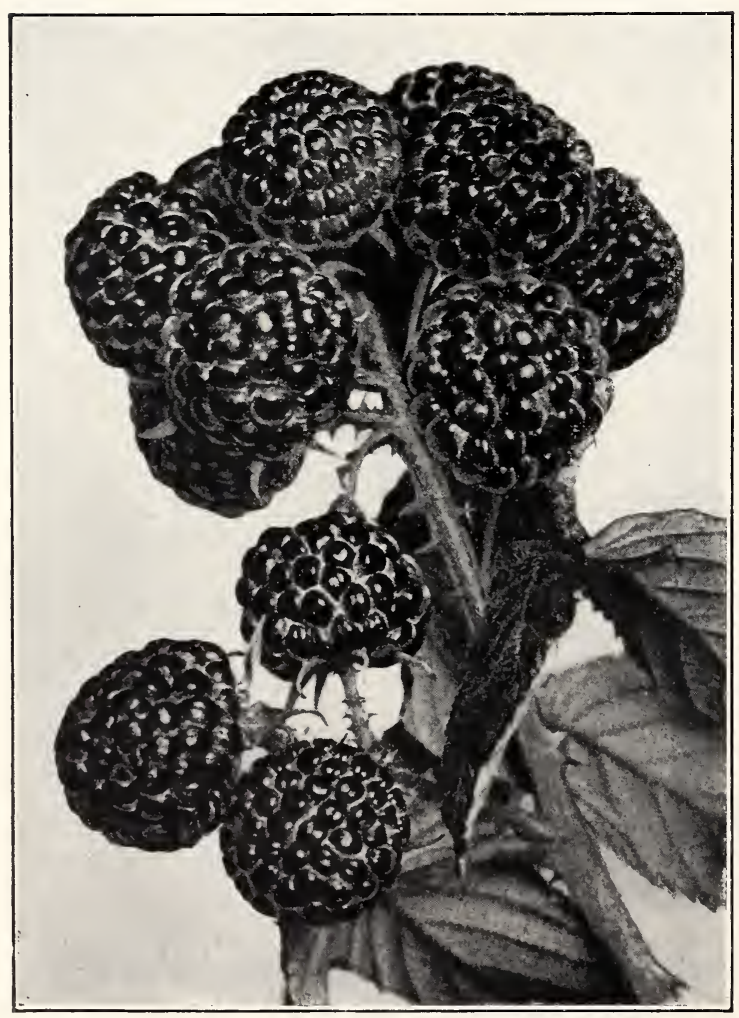

Plum Farmer
KANSAS-One of the best blackcaps. Hardy, handsome, juicy and firm. An excellent field or garden variety. Early.

OHIO-A very strong growing hardy sort; fruit nearly as large as Mammoth Cluster, more productive than any other variety, and one of the most if not the most valuable for market.

PLUM FARMER-This wonderful new black raspberry has been thoroughly tested and is a great favorite for home use, and one of the best commercial sorts for all sections. A vigorous grower, hardy and very productive; one of the best to withstand drought. Fruit enormously large, covered with a grayish bloom like the bloom on a grape; matures early, easily picked, ships well, sells at highest prices. Early.

\section{Red and Purple Raspberries}

COLUMBIAN-The greatest raspberry of the age. It is a seedling of the Cuthbert, grown near the Gregg, and is believed to be a cross between the two. It is enormously productive, of large size and excellent quality. Season of fruiting, from July to August 15th. It has stood 28 degrees below zero without injury, and is propagated from the tips and does not sucker. The color is dark red; adheres to the stem, does not crumble in picking and is a splendid shipper. It has yielded over 8,000 quarts per acre. Mid-season.

CUTHBERT (Queen of the Market) - A good quality, medium season berry; large, sweet and palatable; rich crimson in color. One of the leaders on all markets. Late.

\section{Raspberries make a good} hedge or property boundary line. 
HERBERT-Very hardy, canes strong and vigorous; bright red, the largest of all red raspberries; sweet, juicy. Fine for table use. Enormously productive.

LATHAM-A Big Money Maker for Berry Growers. This ability of Latham to produce so heavily, together with the fine appearance of the fruit and its splendid shipping qualities make it one of the most profitable Red Raspberries now grown. Its extreme hardiness and splendid vigor insure big crops. It stands shipping well and tops the market. It combines all of the good qualities for profitable berry raising.

MARLBORO RED - Large size, light crimson, good quality and firm. Hardy and productive.
ST. REGIS-This everbearing red raspberry bears the first season. One of the greatest raspberries ever introduced. Plants of the St. Regis put out in the fall or early April gave ripe berries on the 20 th of June. For four weeks thereafter the yield was heavy and the canes continued to produce ripe fruit without intermission until late October. The berries were large and beautiful and full flavored to the very last. The St. Regis is the only raspberry, as far as known, that is practically sure to produce a crop of fruit the season planted. Awarded the highest certificate of merit by the American Institute of New York.

\section{Blackberries}

$\mathrm{N}$

EARLY all of the blackberries will bear on good fruit land, particularly good on sandy soil. They require the same culture as raspberries. Keep soil free from weeds and grass. Plant in rows of seven feet apart if in field and five feet apart for garden. When the canes reach the height of three feet in summer pinch off top; this will cause them to throw out laterals. Setting plants $7 \times 3$ feet apart you can get 2,078 plants to an acre; $5 \times 3$ feet apart will allow 2,904 plants to acre.

ANCIENT BRITON-One of the best old varieties. Vigorous, healthy and hardy. Producing large crops with fine quality, bringing highest market price. Will bear in far North, Central or South.

BLOWERS-"The giant of all blackberries." An upright, mammoth grower; very hardy and enormously productive. A single plant produced over 2,000 berries. It commences to ripen about the middle of July and bears about two months.

ELDORADO-A strong growing, hardy type. Berries are large and exceptionally black. Sweet and well flavored and almost entirely free from hard core. Keep well after picking.

ERIE-Ripens earlier than any other sorts. A strong grower and great bearer, producing larger, sweeter berries.

RATHBUN - Origin, Western New York. A strong, erect grower with strong stem, branching freely; will root from tip of branches like a raspberry. Hardy, having endured 20 degrees below zero, and produced a good crop. Forms a neat, compact bush 4 to 5 feet high, producing its immense fruit abundantly. Fruit is sweet and luscious, without hard core, of extra high flavor, jet black, small seeds; firm enough to ship and handle well. Very large size, resembling the Wilson and fully equal to that grand variety, with the addition of hardiness.
SNYDER-Medium size. Plants hardy, healthy and vigorous. This blackberry bears well and is considered a profitable berry. Early.

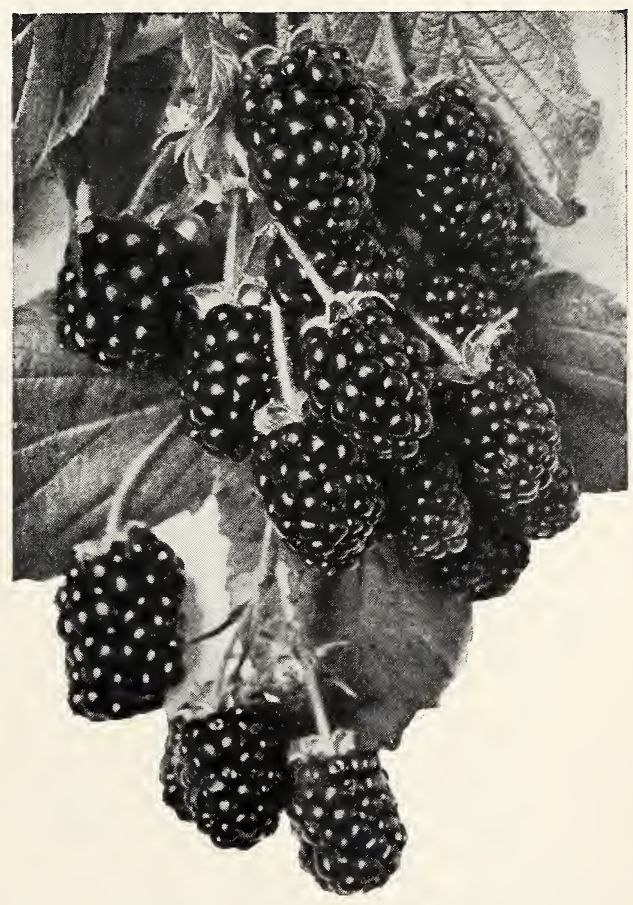

Blowers 


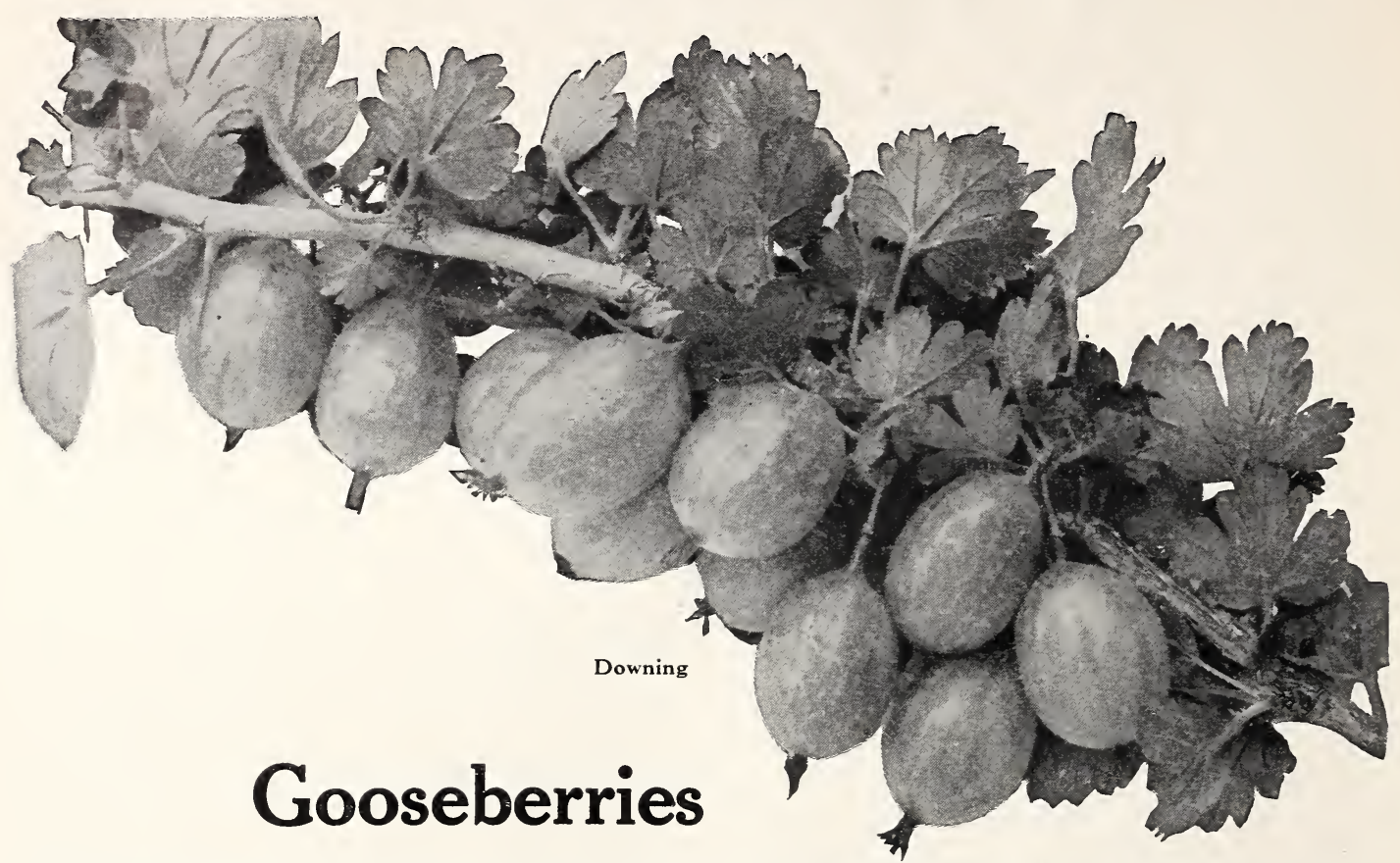

THE interest in and demand for this fruit is constantly growing. It is cultivated more and more extensively both for home use and market. It requires same care as currants. Good plants should produce 200 bushels per acre the third year after planting; 300 to 400 bushels the fifth year.

DOWNING-Large, handsome, pale green gooseberry of splendid quality. Soft and juicy; excellent for family use and profitable for market. Mid-season.

HOUGHTON-Roundish, medium in size; sweet, very productive. Mid-season.

\section{Currants}

Currants are always in big demand for jellies, jams and preserves. They are easily grown and very hardy. Grown for market, they are very profitable, an acre yielding upward of 200 bushels, which command a handsome price.

CHERRY - A standard variety of red currant; of good quality and medium season. Fruit is large and of good market value. Early.

FAY'S PROLIFIC - Ranks among the most popular red currants. Very productive and hardy. Fruit easy to pick and of excellent quality. Season early to medium.

PERFECTION-A beautiful bright red currant, a size larger than Fay. Very productive and of superior quality. Especially recommended for northern sections. Clusters are compact and easy to pick.

WHITE GRAPE-Medium season variety, of best quality. Immensely productive and commercially successful.

\section{Rhubarb or Wine Plant}

The plants should be set four feet apart each way, and the stalks will be fit for use the second season after planting.

MYATT'S LINNAEUS-Those who have never grown this variety, which is of superior quality, will hardly recognize the old "Pie Plant." It is an early, tender variety, without being in the least tough or stringy, with a mild, sub-acid flavor.

VICTORIA-Growth of medium size with stalks tender and of fine flavor; a favorite for pies.

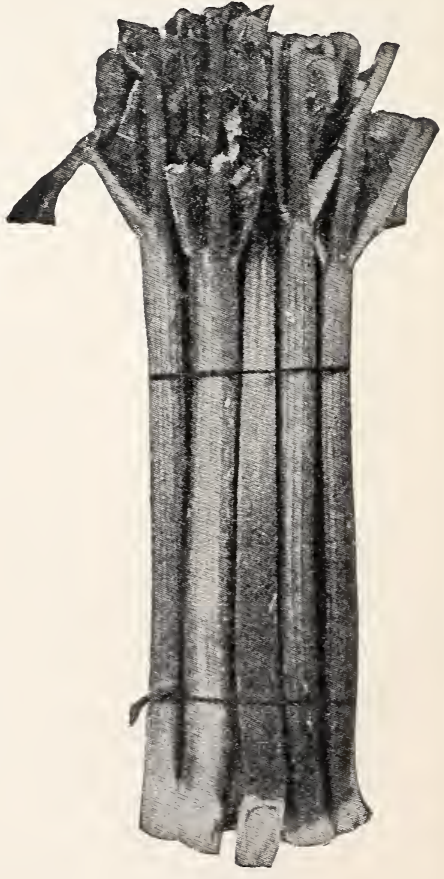

Myatt's Linnaeus Rhubarb 


\section{Strawberry Plants}

COR the home garden or for commercial planting, strawberries come first among small fruits. If planted for home use, a very small bed will yield a large amount of berries.

Commercially, they rank among the highest money-makers. Strawberries are the fruit for big profits on small space. Plants should be kept moist until ready to plant. As some varieties are imperfect in propagation, they should be planted near those that are perfect in order to bear. Each variety is marked, whether perfect or imperfect.

Our plants are taken from young beds, fresh dug before shipment; plants are well rooted. Buy strawberry plants now and start growing one of the best and most profitable crops to be grown. Strawberry plants may be sent by mail.

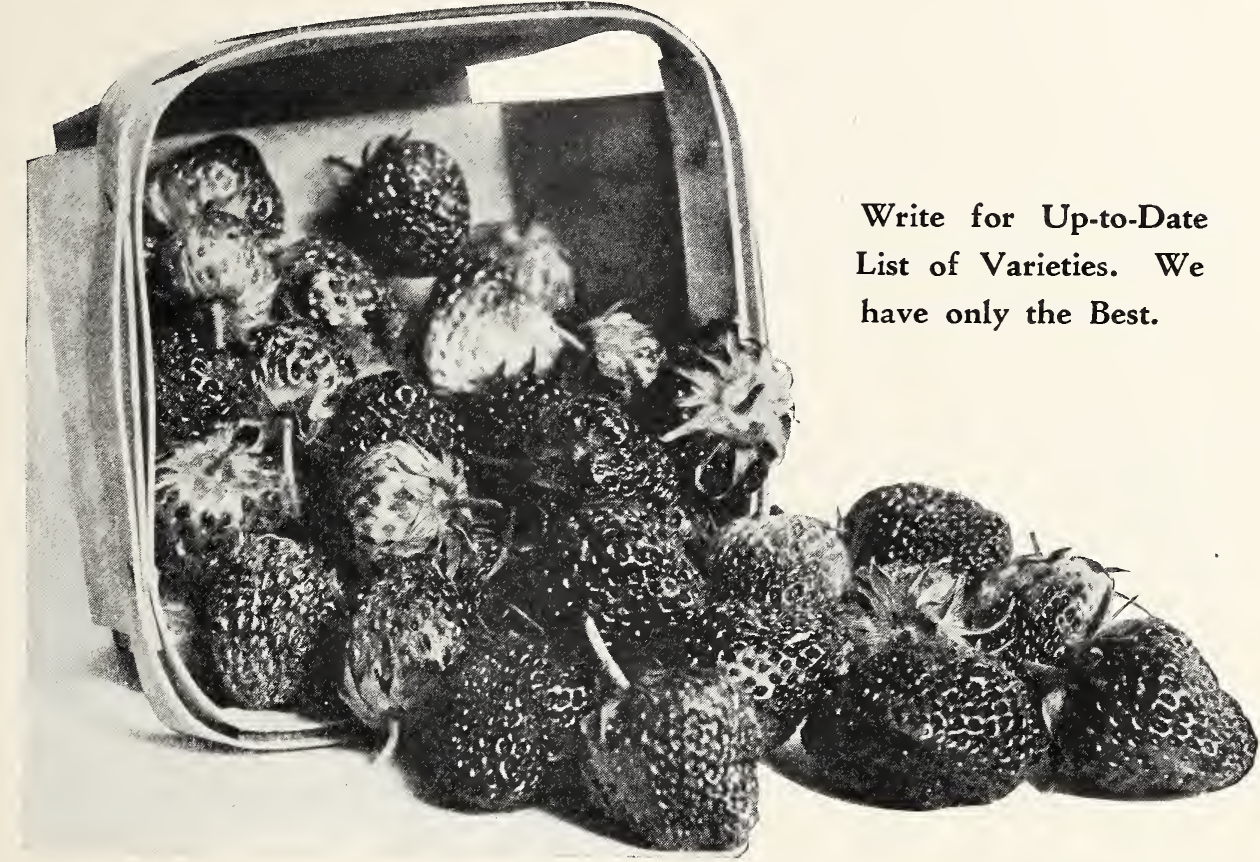

Strawberries are Immensely Popular and Highly Profitable

\section{DIRECTIONS FOR PLANTING}

We advise planting strawberries in rows five feet apart and the plants one foot apart. This would require 8,700 plants to the acre or a trifle over 50 plants to the rod of land. In small gardens it is often advisable to plant them one foot apart each way. With good care, one can reasonably estimate one pint of fruit to the plant. A number of the varieties we have listed produced from ten to fifteen thousand quarts per acre last year. There is a permanent demand nowadays for all the strawberries that a man can raise. The canning factories will take all they can get at a fair price, which will net the farmer from $\$ 250$ to $\$ 800$ an acre, depending on the care given to the plants and crop.

\section{SPRING DELIVERY ONLY}

We Cannot Fill Orders for Strawberries for Customers South of Virginia or

$$
\text { West of Kansas }
$$

Strawberry plants are sent direct to the customer by Parcel Post or Express, depending on size of order. We guarantee delivery in good shape, as plants are dug and shipped the same day. No plants carried over night. Every plant shipped fresh and in perfect order.

\section{LOGAN BERRY}

Ripens early, soon after strawberries. Fruit very large, of dark red color. Has a delicious flavor.

\section{DEWBERRIES}

LUCRETIA - The best and most dependable dewberry. Large, jet black, highly flavored and hardy. A profitable market sort. 


\section{Correct Planting of Trees and Shrubs}

T HE failures experienced in the planting of Trees, Shrubs, etc., result from a want of knowledge of conditions necessary to success, or from a careless disregard of them. Many nurserymen are blamed for what might easily have been avoided had the planter consulted the plain wants and requirements of the stock and given it at least a fair chance to grow and do well. We are interested in the success of every article we send out; we take the greatest pains to place every item in the hands of our customers in the best possible condition, and in order to furnish some precautions which our experience suggests, and urge to a more cautious and considerate culture, we give a few hints on such points as are most essential.

\section{How to Care for Trees on Arrival}

If not ready to plant on arrival, unpack the trees, but do not leave the roots exposed to freezing temperature. Dig a trench in some high and dry ground and heel in, covering the roots with earth, and follow directly with plenty of water around the tree. You can leave them in the trenches until you are ready to set out. If frozen on arrival, leave in the boxes and place in cellar or in a cool, dark room that is free from frost,

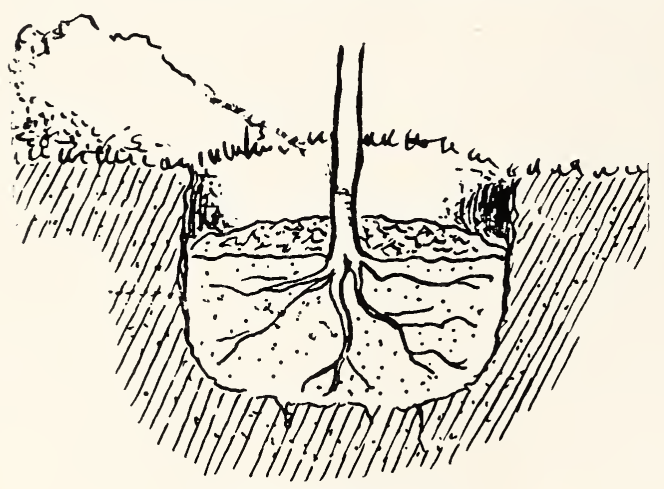

Planting Standard Trees

and let them remain until the frost has disappeared. If no cellar, cover with sawdust or bury in sandy soil until frost has gone. Do not expose frozen trees to heat, light or air. Trees frozen solid will not be injured if handled in this way. If too dry from exposure or transit, bury in earth or place in water from 10 to 20 hours.

How to Prepare the Soil

The soil should be dry for fruit trees, either natural or by drainage. They will not thrive on damp ground. The land should be plowed two or three times and worked well with spring tooth drag or pulverizer previously to the planting. New land needs no manure, but if you wish to set an orchard on land having green crops, it is a good plan to fertilize either with plenty of barnyard manure or turn under a growth of clover. Give the land as good a preparation as for wheat, corn or potatoes and your trees will show rapid growth, and will fruit earlier.

Planting-Dig holes large enough to admit the roots of the tree to spread out in their natural position; then, having the tree pruned as before directed, let one person hold it in an upright position, and the other shovel the earth, carefully putting the finest and the best from the surface in among the roots, bringing every root in contact with the soil. When the earth is nearly filled in, a pail of water may be thrown around the roots; then fill in the remainder and tread gently with the foot. The use of water is seldom necessary, except in dry weather early in fall or late in spring. Guard against planting too deep; the trees, after the ground settles, should stand in this respect as they did in the nursery. Trees on dwarf stock should stand so that all the stock is under the ground, and no more. In very dry, gravelly ground, the holes should be dug twice the usual size and depth, and filled in with good loamy soil. Keep grass and weeds away from trees.

Standard Trees-They vary from four to six feet in height, with naked stems or trunks, and a number of branches at the top forming a head. These branches should all be cut back to within three or four buds of their base. This lessens the demand upon the roots, and enables the remaining buds to push with vigor. Cut off smoothly all bruised or broken roots up to the sound wood.

Leave about four side or scaffold branches and cut these back to six or eight inches. The middle shoot should be cut back to ten or twelve inches and left as a leader.

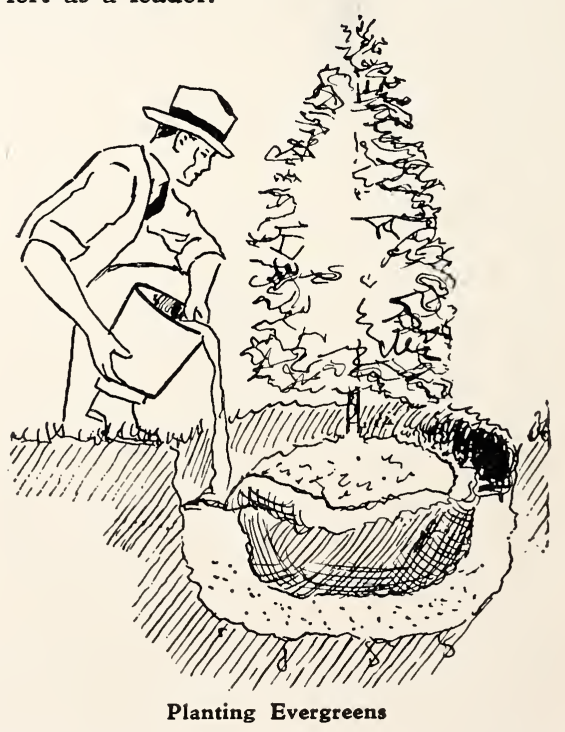

Evergreens-Dig the hole a foot larger and deeper than the root ball. Place some good loamy top soil in hole and set tree a trifle lower than 
it stood in the nursery. Do not remove burlap, as it disturbs root soil. It is only necessary to roll it back or cut it away from the top as shown, as the remainder will soon rot away. Then fill up around ball with good top soil, packing firmly by tramping or settling with water. Finish with loose soil and straw mulching.

Planting a Hedge-First lay out the course of your hedge trench with stakes and white string for the double purpose of squaring up with sidewalks or boundary lines and to aid in digging in a straight line. Dig one side of trench wall straight

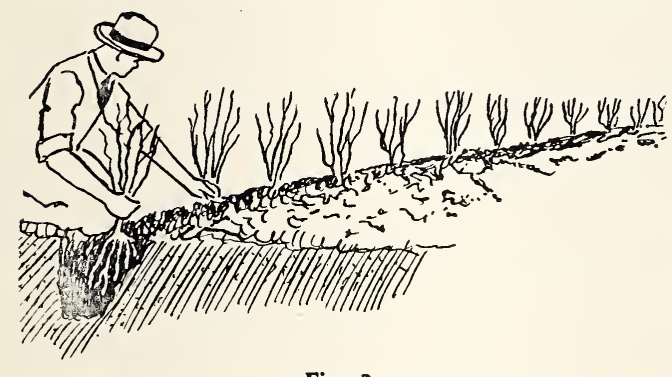

Fig. 3

Planting a hedge in straight walled trench as an aid to setting out in straight line. downward, placing plants against this side to make a straight hedge. Set the plants a trifle lower than they stood in the nursery for a hedge dense at the bottom.

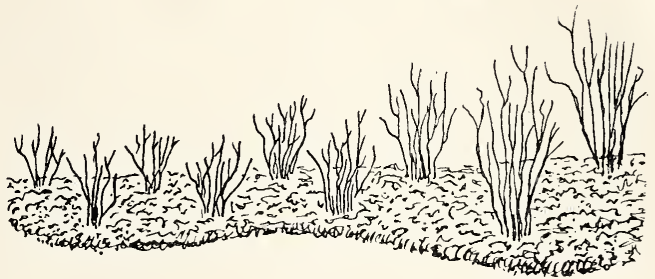

Fig. 4

A shrub bed showing spacing and arrangement of large and small shrubs.

Planting Shrubs-Prepare shrub bed by carefully marking its artistic outline and spading up the ground to the depth of a foot or more. Work up the earth with a rake and mound the bed slightly above the original sod level. In setting out shrubs keep in mind that the larger growing varieties should be set somewhat farther apart than the low growing species, which do well and show up better when closer together. A zig-zag or staggered setting of the plants makes the best arrangement.

\section{Cultivation and Pruning}

$\mathrm{B}$ LOOMING early flowering shrubs should be pruned directly after blooming. Late flowering shrubs should be pruned early in spring while dormant. The early blooming shrubs produce bloom each year on the wood growth made the previous year. The late blooming shrubs produce bloom on the wood growth made the year of blooming.

Pruning, after the first year, should be varied according to the purpose of the planter, and the variety of the trees. They should be trimmed as early as possible up to the height it is intended the future head should be, that the cutting off of large limbs may not in the future be necessary. After the removal of the lower branches till the head has reached the desired height, the only pruning needed is to remove such branches as are crossing or interfering with each other and to keep the head in symmetrical shape and open to sun and air. Trees should receive proper shape by pruning early in the spring of each year, while they are young, and very little pruning will be needed afterwards.

Dwarf Trees, if two or three years growth, with a number of side branches, will require pruning. The branches must be cut into the form of a pyramid by shortening the lower ones, say onehalf, those above them shorter, and the upper ones around the leading shoots to within two or three buds of their base. The leader itself must be shortened back one-half or more. When trees have been dried or injured much by exposure, the pruning must be closer than if in good order.

Staking-If trees are tall or in exposed situations, they should be supported by stakes to prevent injury from wind. Staking is done in the best manner by driving two strong stakes firmly in the ground, one on each side of the tree, about a foot from it, and fastening the tree between them with bands of straw or other soft material.

Mulching-This is properly done by placing a layer of coarse manure or litter, from three to six inches deep, about the tree, extending one or two feet further in each direction than the roots. This keeps the ground moist and of an even temperature; renders watering unnecessary and is in

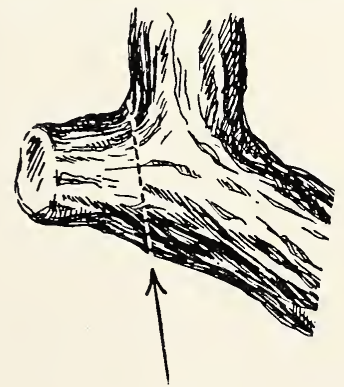

Fig. 5

Do not leave a stub when you cut off a branch. It will not heal over and decay will soon eat into and destroy the limb. Prevent this by cutting close as indicated by dotted lime. 
all respects preferable. Trees properly mulched are more certain to live and also make better growth than those not so treated.

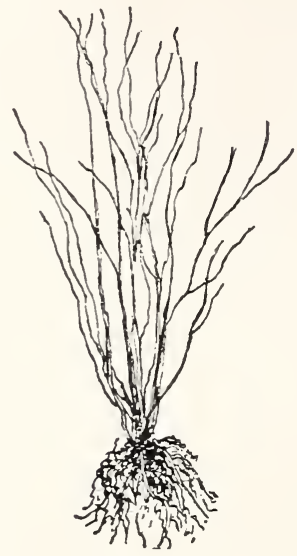

Fig. 6

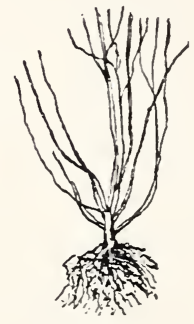

Fig. 7
When pruning the shrubs with slender branches they may be headed back, as shown in Figure 7 , or thinned out and only slightly cut back, as in Figure 6 .

Cultivation After Planting-Many cultivators, after going to great trouble and expense in selecting and planting trees, fail by neglecting that aftercare and attention that is equally essential. Caterpillars and Canker Worms, Grubs and Borers, Slugs and Aphis, Disease and Blight must be watched for, and remedies faithfully applied. The wants of the trees must be foreseen and a faithful effort made to ensure health and productiveness. For such care the cultivator will be well repaid with thrifty, shapely trees and abundant crops of superior fruit. His neighbor, with perhaps better soil and advantages at the outset, and equal care and experience in planting, having neglected these apparently trivial, but really important matters, sees instead of thrifty trees loaded with luscious fruit, a few mossy, scraggy specimens.

Those who are obliged to plant trees in fields of grain and grass, should see that all such are carefully mulched with coarse manure and that the ground is kept loose and moist about the tree. A hoed crop is preferable in such plantations for the first five years. After this time, Standard Apple, Pear and Plum Trees will grow and produce fairly in turf. The Dwarf Trees and Peaches should be well mulched every year with coarse manure, and the ground thoroughly cultivated.

Grape Vines - Require a dry, mellow, welldrained soil, deeply worked and well enriched, with a warm, sunny exposure. In planting give the roots plenty of room and settle the soil firmly about them. A strong vine may be allowed to grow the first season without pruning; in Novem. ber or December following, after the vine is dormant, the growth should be cut back to three or four buds; the next season allow but two buds to grow, which should make canes seven to ten feet long and be cut back to four or five feet, ready for fastening to the trellis. Finer grapes and larger crops will be secured where there is not an excess of vine. For the subsequent pruning of vines, as well as trees, planters would do well to consult some practical works on the subject.

\section{Pruning Strawberry Plants and Herbaceous Perennials}

It is customary when setting these plants to remove all but two or three leaves and these may be partly cut away. It is also well to cut back the roots, especially if they are more than five inches in length. It will then be easier to bring the soil in contact with the individual roots.

Berries-Should have strong soil and be kept under constant cultivation. Mulching is of special value. Raspberries and Blackberries should have the old canes cut out each year, and new canes pinched off when three feet high. If the position is at all exposed, it is well to raise a mound be. tween the hills late in the fall, bend the canes over this mound and peg them down during the winter. Strawberries should be mulched late in the fall; uncover the crowns early in the spring, remove the mulch after fruiting and spade in light dressing of manure. If set for fruit, keep the runners cut off.

Currants and Gooseberries should be mulched every spring and well pruned, so that new wood may have a chance to grow. The ground about them should be kept in good condition by manure and cultivation. The worms may be destroyed with certainty by applying White Hellebore powder shaken from a coarse bag as soon as they appear, and repeating the operation once or twice.

Roses-Nothing repays good care better than Roses. They should have a deep, rich, well-drained soil, thorough cultivation and plenty of manure. They should be pruned every spring before the buds swell, cutting back all the last year's growth to three or four buds, excepting Climbing or Pil-

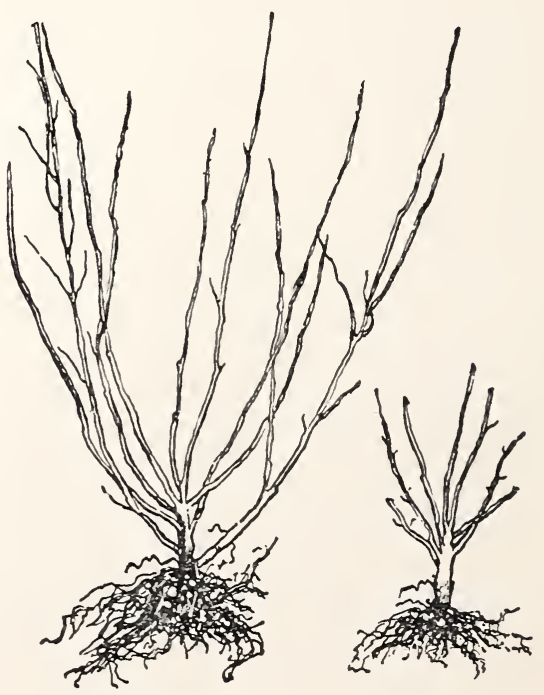

Fig. 8

Fig. 9

Plants having stout stems, such as hydrangeas, roses, etc., should be cut back to two or three buds, as shown above. 
lar Roses, which may first be allowed partly to cover the space desired; old, decayed branches should never remain. Climbing, Moss and Hybrid Perpetual sorts require no protection, but the socalled "tender" varieties should be covered with leaves, straw or branches of evergreens, late in the

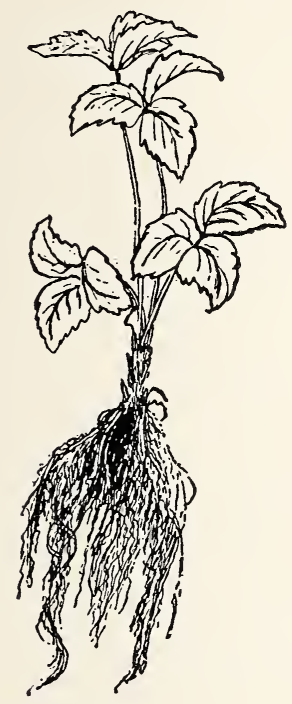

Fig. 10

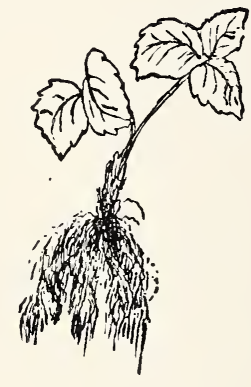

Fig. 11
Showing the Pruning of Root and Branch of Strawberry Plants.

fall; or heel over above the ground. If the "thrip" or fly appears it may be disposed of by applying decoctions of tobacco steeped in water. Every autumn, compost should be placed around the stems of the plants and spaded into the ground the following spring.

Budded roses should be planted deep in the ground so that the bud is slightly covered with earth, and then during the growing season should be carefully watched and every shoot or sucker that grows from the wild root below the bud, should be cut off as soon as it makes its appearance. If this is done the budded shoot or stock receives the full strength of the plant and grows rapidly and blooms freely. If it is not done and the wild shoots or suckers are allowed to grow, they take all the strength of the roots and in a short time the budded shoot dies and nothing is left but the wild shoots from the roots, which, of course, bear nothing but ordinary wild roses.

Pruning Tools-It pays to use the best for the quicker and cleaner work that can be accomplished with strong, sharp tools. Hand shears especially must be of high grade to prevent springing and dissatisfaction in use. Use ladders in preference to climbing around in the tree when pruning, as the latter practice is damaging to the bark, limbs and fruit spurs.
Mulching-This is not often necessary as the young orchard should be well cultivated. If this is not possible, the area immediately around the trunk should be kept open and hoed often and a mulch of weeds, grass, leaves or manure can be used as a ground covering under the branches.

Fertilizing-Young orchards, planted on prepared land, should need little if any fertilizing for the first few years, other than the cover crops. When necessary an application of barnyard manure under the branches will allow the rain. drip from the foliage to carry the needed nourishment downward to the spreading roots.

\section{Number of Trees or Plants to Acre}

\begin{tabular}{|c|c|c|c|c|c|}
\hline 2 feet each & way $\ldots \ldots 10,890$ & 15 & feet & each & way \\
\hline 3 feet each & way ..... 4,840 & 18 & feet & each & way \\
\hline feet each & way $\ldots \ldots .2,723$ & 20 & feet & each & way \\
\hline feet each & way $\ldots . .1,742$ & 25 & feet & each & way \\
\hline feet each & 1,210 & 30 & feet & each & way \\
\hline feet each & way & 33 & feet & each & way \\
\hline eet each & way & 40 & feet & each & way \\
\hline
\end{tabular}

12 feet each way .... 302

To estimate the number of plants required for an acre, at any given distance, multiply the distance between the rows by the distance between the plants, which will give the number of square feet allotted to each plant, and divide the number of square feet in an acre $(43,560)$ by this number, the quotient will be the number of plants required.

\section{Distance for Planting}

\begin{tabular}{|c|c|c|}
\hline Apples, Stand. .... & $30.40 \mathrm{ft}$. & $\ldots .8 \times 10 \mathrm{ft}$. \\
\hline Apples, Dwarf & $8.10 \mathrm{ft}$ & Currants \\
\hline Pears, Standard & $18-20 \mathrm{ft}$. & Gooseberries \\
\hline Pears, Dwarf ...... & $10 \mathrm{ft}$. & Raspberries, Red... 3x $6 \mathrm{ft}$. \\
\hline Peaches ....... & $16.18 \mathrm{ft}$. & Raspberries, Black $3 x$ \\
\hline Nectarines and & & Blackberries ........... \\
\hline Apricots $\ldots \ldots$. & $16-18 \mathrm{ft}$. & Strawberries, rows. \\
\hline Cherries, Sweet & $18-20 \mathrm{f}$ & Strawberries, in \\
\hline Cherries, Sour.. & $15.18 \mathrm{f}$ & beds $\ldots \ldots \ldots . .11 / 2 \times 1$ \\
\hline Plums .............. & $16.20 \mathrm{f}$ & Aspar., i \\
\hline Quinces & $10.12 \mathrm{ft}$. & Aspar., in field....... $1 \mathbf{x}$ \\
\hline
\end{tabular}

\section{Age at Which Different Trees Should Fruit}

This varies greatly with the different varieties, for instance, the "Duchess" standard apple often fruits the second year after transplanting, and bears very regularly, while the "Northern Spy" seldom fruits in less than seven years after transplanting, though one of the best apples and a prolific bearer when of fruiting age. The average time it takes for standard apples to fruit is four or five years.
Dwarf Apples, 2 years.

Stan. Pears, 3 to 4 years.

Cherries, 3 to 4 years.

Gooseberries, 2 years.

Grapes, 2 years.

Quinces, 3 to 4 years.
Blackberries, 3 years. Crab Apples, 2 years. Dwarf Pears, 2 years. Plums, 3 to 4 years. Currants, 2 years. Raspberries, 2 years Roses generally bloom the first year. 


\section{Spraying Methods and Formulas}

Arsenite of Lead

Arsenite of Lead, 4 to 6 pounds. Water, 100 gallons.

\section{Ammoniacal Copper Carbonate}

The copper carbonate is best dissolved in large bottles, where it will keep indefinitely, as it should be diluted with water as required. For the same purpose as Bordeaux.

\section{Copper Sulphate Solution}

Copper sulphate, 1 pound. Water, 25 gallons. This should be used only before the foliage appears. It is easily applied, and acts as a germicide and disinfectant. In simple solution copper sulphate is very injurious to foliage. When lime is added, as in making Bordeaux mixture, its corrosive action is neutralized and injury to the foliage prevented. In this way a larger quantity of bluestone may be used, and it adheres to the foliage better by the agency of lime.

\section{Kerosene Emulsion}

$\begin{array}{lllllllll}\text { Hard Soap } & \cdot & \cdot & \cdot & \cdot & . & . & 1 / 2 & \text { pound } \\ \text { Boiling Water } & \cdot & \cdot & \cdot & \cdot & . & . & 1 & \text { gallon } \\ \text { Kerosene } & \cdot & \cdot & \cdot & . & . & . & 2 & \text { gallons }\end{array}$

Dissolve the soap in hot water and while hot add the oil. Pump the liquid back into itself 5 or 10 minutes until it becomes a creamy mass.

For a 10 per cent emulsion add 17 gallons of water to 3 gallons of the above emulsion.

For a 15 per cent emulsion add $10^{1 / 2}$ gallons of water to 3 gallons of the above emulsion.

\section{Lime Sulphur Salt Solution}

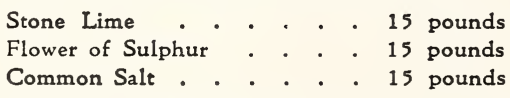

Put lime in kettle, add three or four buckets hot water. While lime is boiling, add sulphur and stir briskly. If contents of kettle is likely to boil over, add another bucket of hot water. When the lime and sulphur have boiled for ten minutes, add salt, and cook until the solution becomes dark amber in color. An hour is sufficiently long to cook the mixture, but if it is not of the right color at this time, cooking should be continued. When the mixture has been properly cooked, there ought not to be more than a pint or so of residue left in the kettle. At the beginning of the cooking, stir continually, but after a few minutes, occasionally stirring will suffice. When the cooking is completed, the solution should be strained through a fine sieve, made for the purpose, or through a gunny sack into the pumping barrel or tank and made up to 50 gallons of hot water. The mixture should be applied while hot and preferably as soon after making as possible, always bearing in mind to keep it well agitated while the pump is in operation. Pumps and accessories used should be well washed and cleaned after each time of using.

Concentrated lime-sulphur solutions may be purchased from the manufacturers, of which there are now a large number making a good product, and can be used according to directions furnished with each package.

\section{Bordeaux Mixture}

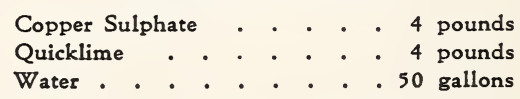

To destroy leaf-eating insects, add four ounces of Paris Green. For Peach, use three pounds each of copper sulphate and lime, and three ounces of Paris Green, on account of the tenderness of the foliage.

Ferrocyanide Test-Dissolve one ounce of yellow prussiate of potash in a pint of water and label "POISON." Drop it into the mixture and if it turns brown more milk of lime should be added. Add milk of lime until the solution will not turn brown.

\section{Tobacco}

Boil tobacco stems, and use at the rate of two gallons of water to each pound of stems, for sucking insects.

\section{Hellebore}

Fresh White Hellebore, 1 ounce. Water, 3 gal. lons.

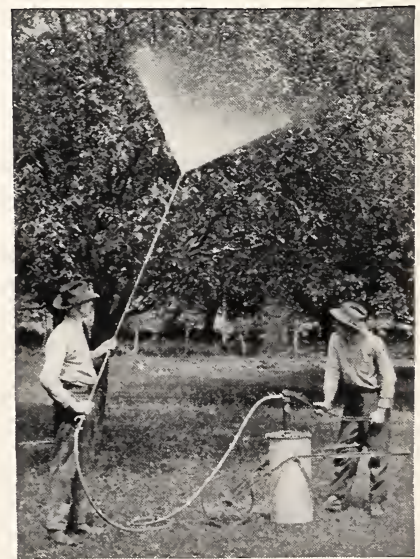

An Effective Weapon Against Insects for Small Orchards 


\section{Spraying Calendar}

T XPLANATION.-While the number of applications recommended will be found desirable in seasons when the fungi are particularly troublesome, a smaller number may often suffice. Those printed in bold face are of the most value, and can generally be made with profit. An asterisk $(*)$ cautions against spraying with poisons while the plants are in blossom; a dagger $(\dagger)$ indicates that there is danger in making applications within 3 weeks of the time the fruit is to be used as food.

\begin{tabular}{|c|c|c|c|c|}
\hline Plants and Diseases & First Application & Second Application & Third Application & Fourth Application \\
\hline $\begin{array}{l}\text { APPLES, } \\
\text { Scab, codling moth, } \\
\text { bud moth, caterpillar, } \\
\text { canker worm. }\end{array}$ & $\begin{array}{l}\text { After the blossoms } \\
\text { have formed, but before } \\
\text { they open, Bordeaux. }\end{array}$ & $\begin{array}{l}\text { Within a week after } \\
\text { blossoms fall, Bordeaux } \\
\text { and Paris Green.* }\end{array}$ & $\begin{array}{l}10 \text { to } 13 \text { days later, } \\
\text { Bordeaux and Paris } \\
\text { Green. }\end{array}$ & $\begin{array}{l}10 \text { to } 14 \text { days later, } \\
\text { Bordeaux. }\end{array}$ \\
\hline $\begin{array}{l}\text { CHERRY, } \\
\text { Rot, aphis, curculio, } \\
\text { slug, knot. }\end{array}$ & $\begin{array}{l}\text { As flower-buds appear, } \\
\text { but before they open, } \\
\text { Bordeaux; for aphis, } \\
\text { use Kerosene Emulsion. }\end{array}$ & $\begin{array}{l}\text { When fruit has set, } \\
\text { Bordeaux and Paris } \\
\text { Green.* }\end{array}$ & $\begin{array}{l}10 \text { to } 14 \text { days later, if } \\
\text { signs of rot appear, re- } \\
\text { peat. }\end{array}$ & $\begin{array}{l}10 \text { to } 14 \text { days later, } \\
\text { Ammoniacal Carbonate } \\
\text { Copper. }\end{array}$ \\
\hline $\begin{array}{l}\text { CURRANT, } \\
\text { Mildew, worms. }\end{array}$ & $\begin{array}{l}\text { As soon as worms are } \\
\text { found on lower and in. } \\
\text { ner leaves, Paris Green. }\end{array}$ & $\begin{array}{l}\text { If they reappear, re- } \\
\text { peat, adding Bordeaux } \\
\text { for mildew. } \dagger\end{array}$ & $\begin{array}{l}\text { If worms still trouble, } \\
\text { Pyrethrum or Helle- } \\
\text { bore.* }\end{array}$ & $\begin{array}{l}\text { After fruit is pick } \\
\text { Bordeaux. }\end{array}$ \\
\hline $\begin{array}{l}\text { GOOSEBERRY, } \\
\text { Mildew, worms. }\end{array}$ & $\begin{array}{l}\text { As leaves open, Bor- } \\
\text { deaux and Paris Green. }\end{array}$ & $\begin{array}{l}\text { In } 10 \text { to } 12 \text { days, re- } \\
\text { peat with both. }\end{array}$ & $\begin{array}{l}10 \text { to } 14 \text { days later, } \\
\text { Sulphide Potash, on } \\
\text { English varieties. }\end{array}$ & $\begin{array}{l}10 \text { to } 14 \text { days later, } \\
\text { repeat. }\end{array}$ \\
\hline $\begin{array}{l}\text { GRAPE, } \\
\text { Fungous diseases, flea } \\
\text { beetle. }\end{array}$ & $\begin{array}{l}\text { When first leaves are } \\
\text { half grown, Bordeaux } \\
\text { and Paris Green. }\end{array}$ & $\begin{array}{l}\text { As soon as the fruit } \\
\text { has set, repeat." }\end{array}$ & $\begin{array}{l}10 \text { to } 14 \text { days later, } \\
\text { repeat. }\end{array}$ & $\begin{array}{l}10 \text { to } 14 \text { days later, } \\
\text { if disease is present, } \\
\text { apply Bordeaux. }\end{array}$ \\
\hline $\begin{array}{l}\text { PEACH, } \\
\text { APRICOT, } \\
\text { Rot, curculio, leaf } \\
\text { curl, mildew. }\end{array}$ & $\begin{array}{l}\text { Before blossoms open, } \\
\text { Bordeaux. }\end{array}$ & $\begin{array}{l}\text { Within a week after } \\
\text { fruit has set, Bordeaux } \\
\text { and Paris Green.* }\end{array}$ & 11 days later, & $\begin{array}{l}7 \text { to } 12 \text { days later. } \\
\text { repeat. }\end{array}$ \\
\hline $\begin{array}{l}\text { PEAR, } \\
\text { Leaf - blight, s c a b } \\
\text { psylla, codling moth. }\end{array}$ & $\begin{array}{l}\text { Just before blossoms } \\
\text { open, Bordeaux.* }\end{array}$ & $\begin{array}{l}\text { Within a week after } \\
\text { blossoms fall, Bordeaux } \\
\text { and Paris Green. }\end{array}$ & 12 days later, & $\begin{array}{l}10 \text { to } 16 \text { days later, } \\
\text { Bordeaux. }\end{array}$ \\
\hline $\begin{array}{l}\text { PLUM, } \\
\text { Fungous diseases, rot, } \\
\text { curculio, knot. }\end{array}$ & $\begin{array}{l}\text { Within a week after } \\
\text { blossoms have fallen, } \\
\text { repeat. }\end{array}$ & $\begin{array}{l}10 \text { to } 12 \text { days later, } \\
\text { repeat. }\end{array}$ & $\begin{array}{l}10 \text { to } 20 \text { days later, } \\
\text { Bordeaux. }\end{array}$ & $\begin{array}{l}\text { Cut out black kinds } \\
\text { on Plum or Cherry } \\
\text { and burn. }\end{array}$ \\
\hline $\begin{array}{l}\text { QUINCE, } \\
\text { Leaf and fruit spots. }\end{array}$ & $\begin{array}{l}\text { When blossom buds } \\
\text { appear, but before they } \\
\text { open, Bordeaux. }\end{array}$ & $\begin{array}{l}\text { When fruit has set, } \\
\text { Bordeaux and Paris } \\
\text { Green.* }\end{array}$ & $\begin{array}{l}10 \text { to } 14 \text { days later, } \\
\text { repeat. }\end{array}$ & $\begin{array}{l}10 \text { to } 20 \text { days later, } \\
\text { Bordeaux. }\end{array}$ \\
\hline $\begin{array}{l}\text { RASPBERRY, } \\
\text { BLACKBERRY, } \\
\text { Anthracnose, rust. }\end{array}$ & $\begin{array}{l}\text { Cut out canes dis- } \\
\text { eased with anthracnose, } \\
\text { and burn. Before buds } \\
\text { open, spray with Copper } \\
\text { Sulphate solution. }\end{array}$ & $\begin{array}{l}\text { When new canes ap- } \\
\text { pear, Bordeaux and } \\
\text { Paris Green.* }\end{array}$ & $\begin{array}{l}10 \text { to } 14 \text { days later, } \\
\text { repeat. } t\end{array}$ & $\begin{array}{l}\text { NOTE.-If orange } \\
\text { rust appears, dig and } \\
\text { burn infected plants. }\end{array}$ \\
\hline $\begin{array}{l}\text { ROSE, } \\
\text { Aphis, worm. }\end{array}$ & $\begin{array}{l}\text { Kerosene } \\
\text { for aphis. }\end{array}$ & $\begin{array}{c}10 \text { days later, Bor- } \\
\text { deaux and Paris Green. }\end{array}$ & $\begin{array}{l}\text { Afterwards keep lice } \\
\text { and caterpillars off by } \\
\text { turning a fine stream } \\
\text { from hose on under } \\
\text { side of leaves. }\end{array}$ & \\
\hline
\end{tabular}

Do not spray with arsenites or copper compounds within 3 weeks of the time the sprayed portions are to be eaten. While there would be no danger of fatal effects resulting, it is best not to run any risk. Bordeaux mixture and other lime compounds should not be used upon rough or full-grown fruits even as late as that time. Not only does the lime disfigure the fruit, but the amount of copper is large.

If the information you seek cannot be found in this calendar, or if your trees suffer from some disease or pest not mentioned above, we advise writing at once to your Agricultural Experiment Station, giving full details and particulars. The Agricultural Experiment Station of your State is established to help you produce more and better fruit and the Director will be very glad to give you all the information necessary to this end. 


\section{INDEX}

Achillea

Cherry, Japan Weeping . 50.5

Chinese Lantern Plant . . . 23

$\begin{array}{lll}\text { Christmas Rose . . . . . } & \text {. } & 36 \\ & & 39\end{array}$

Chrysanthemums : . : $: 36$

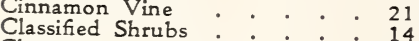

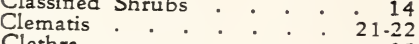

Clethra

Climbing Vines : : : $: 21.22$

Columbine . . . . . . $\quad 36$

Colutea
Corchorus
Coreopsis

Cornus

Crab Apples

Crab, Flowering

Crocus

\begin{tabular}{lr} 
Cultivation and Pruning : & 41 \\
Currants & $63-65$ \\
\hline & 6
\end{tabular}

Daisy, Shasta

Dahlias

Daphne-Cneorum

Day Lily

Decorative Hedges

Delphinium

Deutzia

Color Illustration, p. 2)

Dewberries

Dianthus

Diervilla

Distance for Planting

Dogtance

Dutchman's Pipe

Dwarf Apples

Elder

Eleagnus

Elm

English Walnut

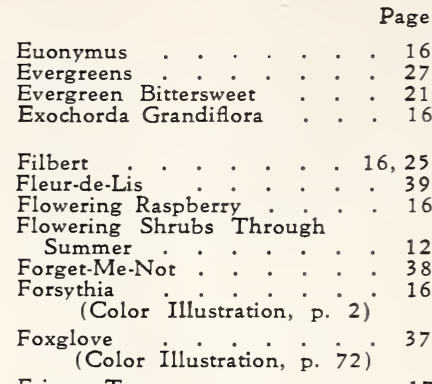

Fringe Tree

Funkia 42.55

Gaillardia

Garden Flowers • • • 37

Gladioli $\cdot \cdot 35.40$

Golden Bell : : : : : $: 416$

Golden Glow : : : : : $\quad 38$

Gooseberries . . . . 60

Grapes $\quad \cdot \quad \cdot \quad \cdot \quad \cdot \quad 36$

Hardy Climbing Vines . . 21.22

Hardy Flowering Shrubs : 15.21

Hardy Perennials. 35

Hedges : : : : : : 26

Heleborus $: 39$

Hemerocallis Flava : : 38

Hibiscus . • . • . . $\cdot 39$

Hickory

Hollyhocks

oneysuckle Bush

(Color Illustration, p. 2)

Honeysuckle, Climbing . . . 22

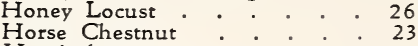

Hyacinths

(Color Illustration, p. 3 ) 17.18

Hypericum Moserianum . . 38

Iris, German . . . . 35, 39

Iris, Japan : : * : * : 39

Japan Quince

Japan Walnut

Judas Tree

Juniper

Kerria

26

Laburnum

Landscape Designs

Larch

(Color Illustration, p. 72)

Lathyrus
Ligustrum

Lilac

Lilies of the Valley

Linden

Locust

Logan Berry

Maiden Hair Tree

Mallow

Maple

Matrimony Vine

Mock Orange

Moss Roses

Mountain Ash

Mulberry

Myosotis

Nectarines . . . . 57

No. of Trees and Plants to Acre 65

Nut Trees . . . . . 25

Oak

Oleaster

25
$-\quad 16$

Ornamental Trees : : 23.25
Page

Peonies . . . . 39.40

Peach, Flowering . . . 25

Peaches Bush : * * * 52.53

Pearl Bush . : . : . : 48.49

Perennials, Hardy ${ }^{\circ} \cdot{ }^{\circ} \cdot \begin{array}{r}48 \\ \text { Pears }\end{array}$

Perennial Pea : . 38

Perennial Planting Plans : 40

(Color Illustration, p. 72)

Physalis Francheti . . . . 36

Pine . . . . . . . 27

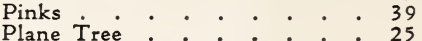

Plane Tree $\dot{0}$ ' 25

Planting of Trees and Shrubs 5462

Plum, Flowering . . . . 19

Plum, Purple-leaved . . . . 19

Poplar . . . . . . . 25

Poppy $: 39$

Potentilla Fruticosa : : : 18

Primrose . . . . . . 38

Primulas . . . . . is 38 (Color Illustration, p. 4)

Pruning . . . . . . 63

Pyrethrum : . . . . $: 40$

Quinces Ornamental : : : : 55

Raspberries . . . . . . 58.59

Red Bud . . . . . . . 23

Red Hot Poker . . . . . 40

Rhododendrons : *: : 27

Rhus . . . . . . 20

Rose Growing : : : : 29.34

(Color Illustrations, p. 70)

Roses, Climbing (Color Illustration, p. 71) 33.34

Roses, Hybrid Perpetual . 29-30

Roses, Hybrid Tea . . : 31.32

Roses, Moss . . . . . 34

Roses, Polyantha : . : : 33

Rose of Sharon Hybrids : : $\begin{array}{r}15 \\ \hline\end{array}$

Salisburia . . . . . 25

Sambucus • $\cdot \cdot \cdot \cdot \cdot \cdot 16$

Shasta Daisy • • • • • 37

Snowball • . . . . 19

. . . . . . 19

Spindle Tree • • • • . 16

(Color Illustrations, p. 3 )

Spray Calendar $\dot{1} \cdot{ }^{\circ} \cdot 67$

$\begin{array}{ll}\text { Spray Methods and Formulas . } & 66 \\ \text { Spruce . . . . . } & 27\end{array}$

Strawberry Plants :. . $^{\circ} \quad .61$

Sumac . : : 20

Sweet Scented Shrub : : 15

Symphoricarpus . . . . 19

(Color Illustration, p. 3)

Tamarix

Taxus

Thorn

Trees and Shrubs, Planting 62

Tree of Heaven . . . . 23

Trumpet Vine : : : : : $\quad 22$

Tulips . . . $\cdot \bullet^{\circ} \cdot{ }^{\circ} 41$

Tulip Tree . . . . . 25

Veronica . . . . . 36

Viburnum Climbing : : : : 2122

Walnut . . . . . 25

Weeping Willow : $: \vdots: \begin{aligned} & 25 \\ & \text { Weigela }\end{aligned}$

Weigela (Color Illustration, p. '2)

When Trees Fruit • • • 65

Windfower $\cdot{ }^{*} \cdot 25$

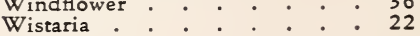

Yew . . . . . . 27 


\section{These Varieties Always in Big Demand}
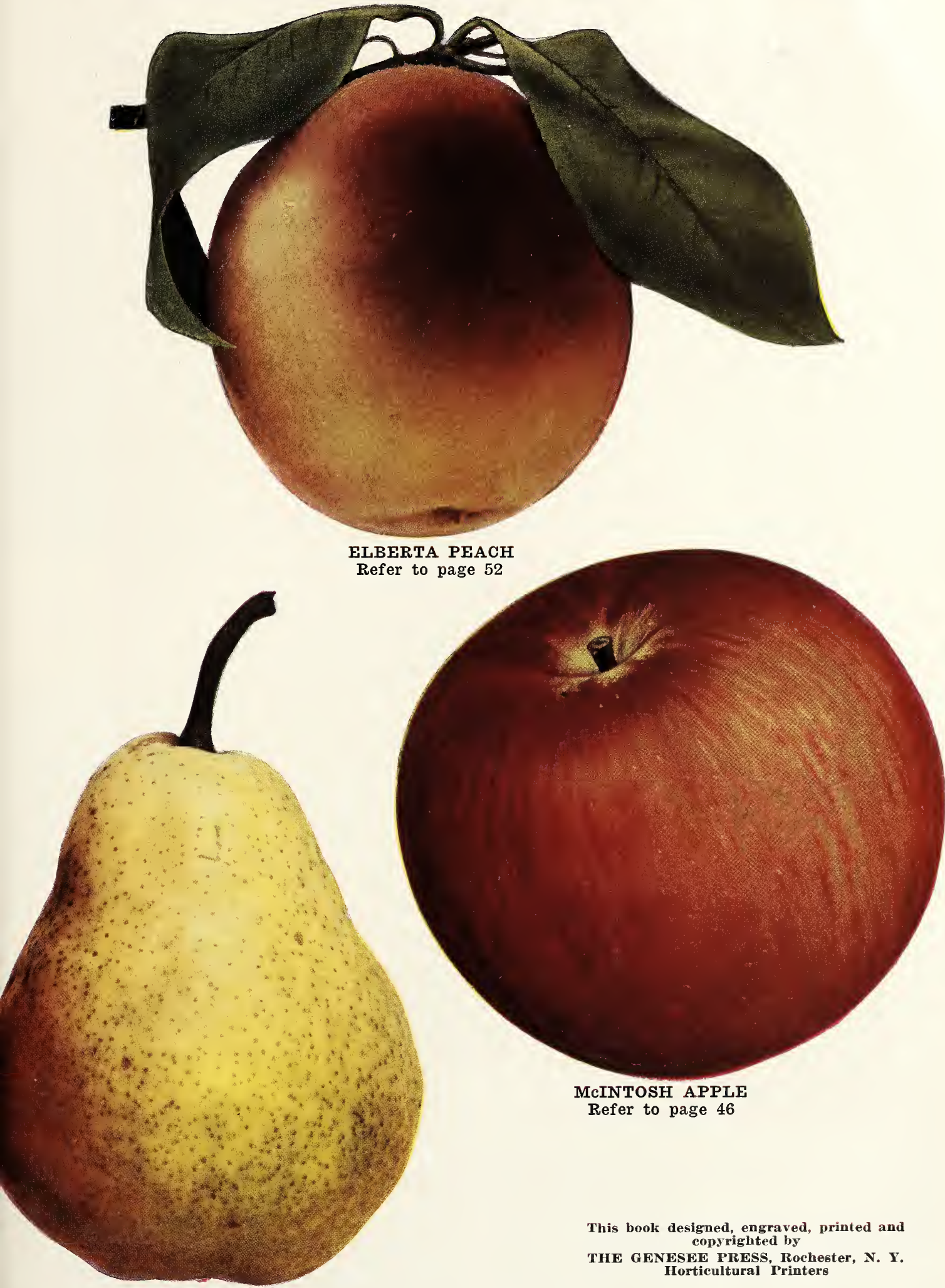

BARTLETT PEAR

Refer to page 48

This book designed, engraved, printed and THE GENESEE PRESS, Rochester, N. Y. Horticultural Printers 


\section{A Vigorous Climber of Intense Crimson Color}

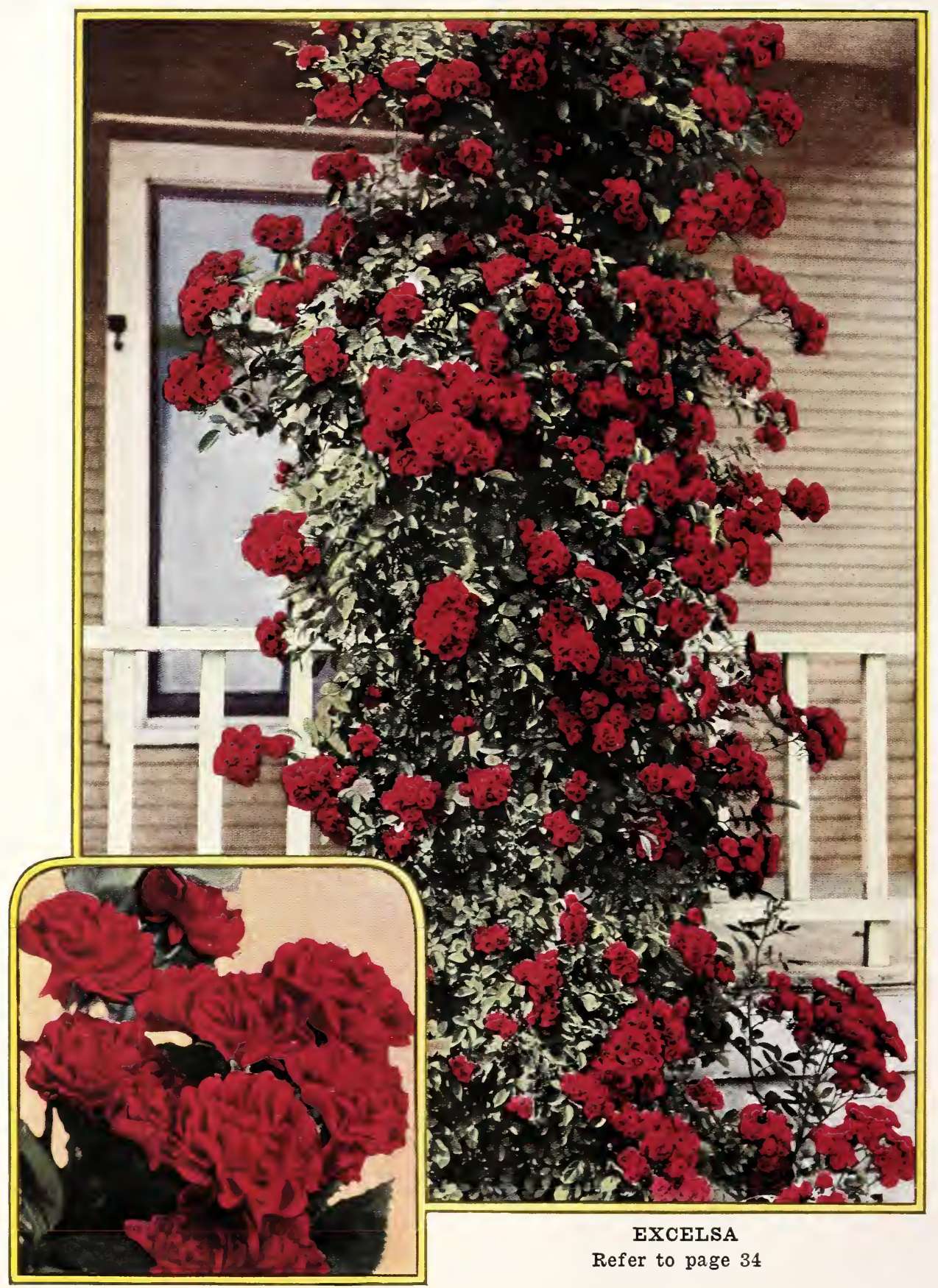

Very hardy. Grows 8 or 10 feet in a single season. A gorgeous bloomer.

Does not require cultivation. 


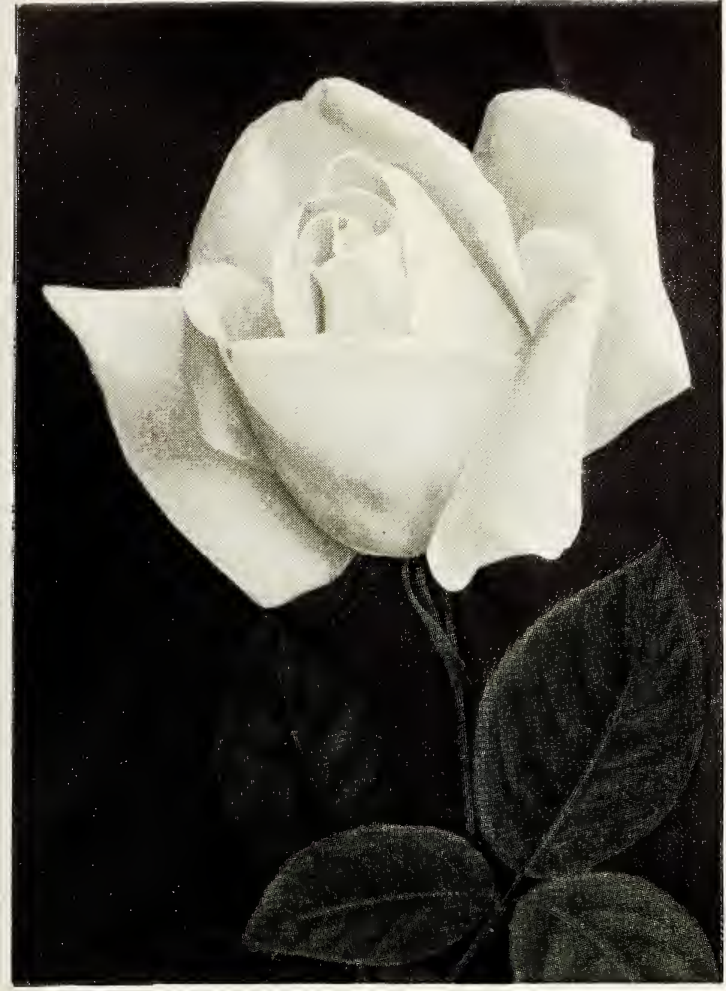

FRAU KARI DRUSCHKI

Refer to page 30

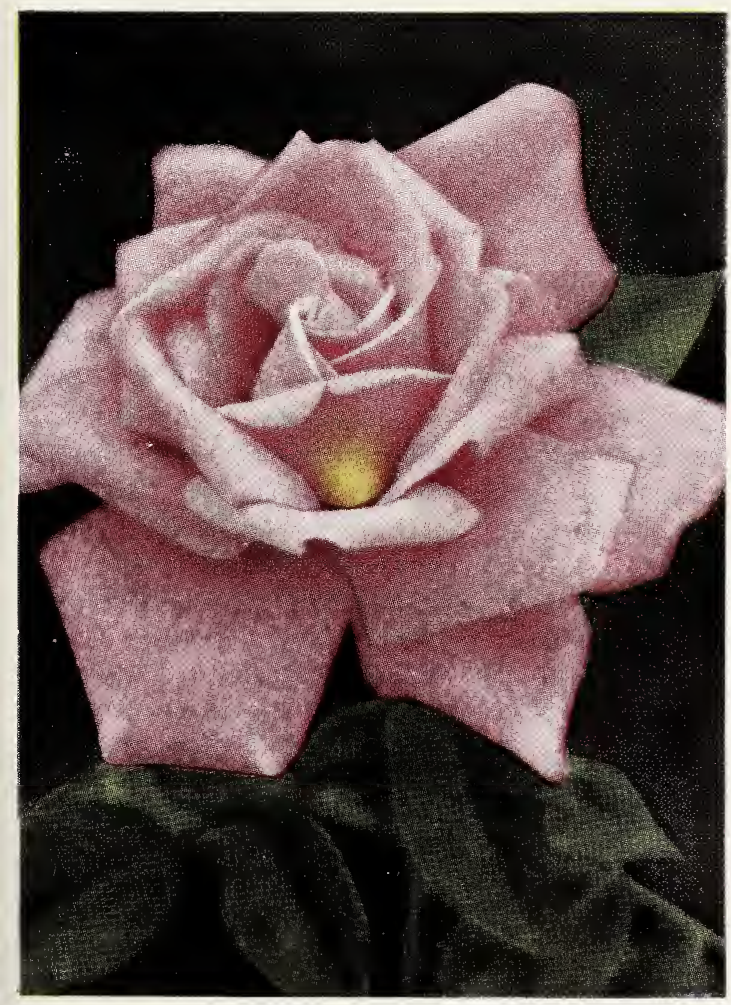

PINK COLUMBIA

Refer to page 31

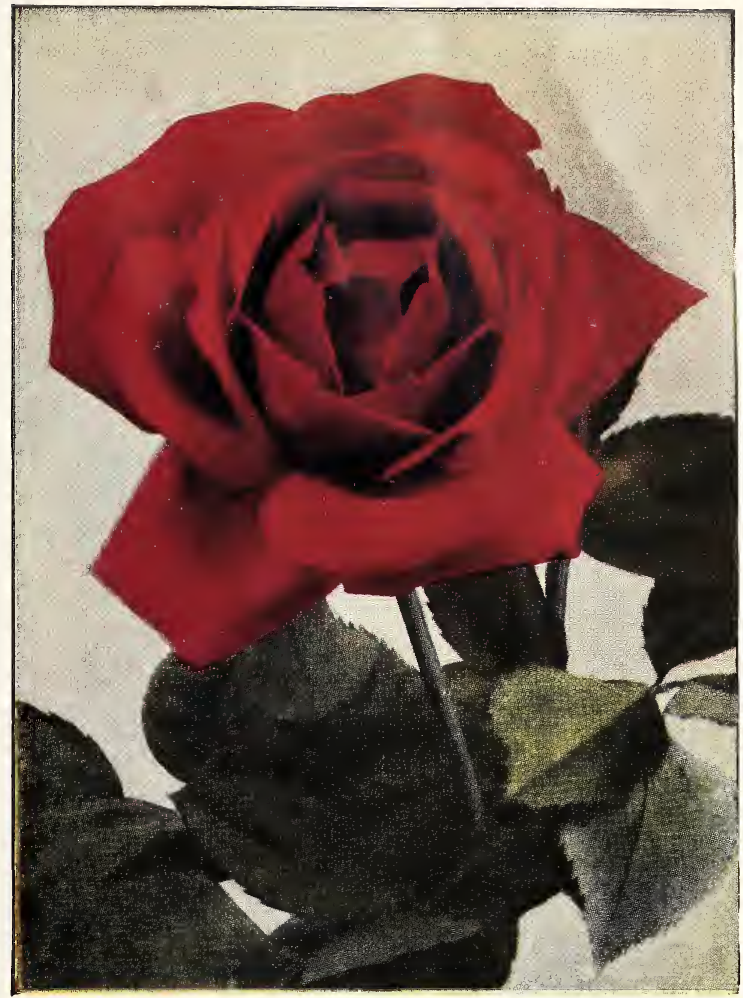

GRUSS AN TEPLITZ Refer to page 31

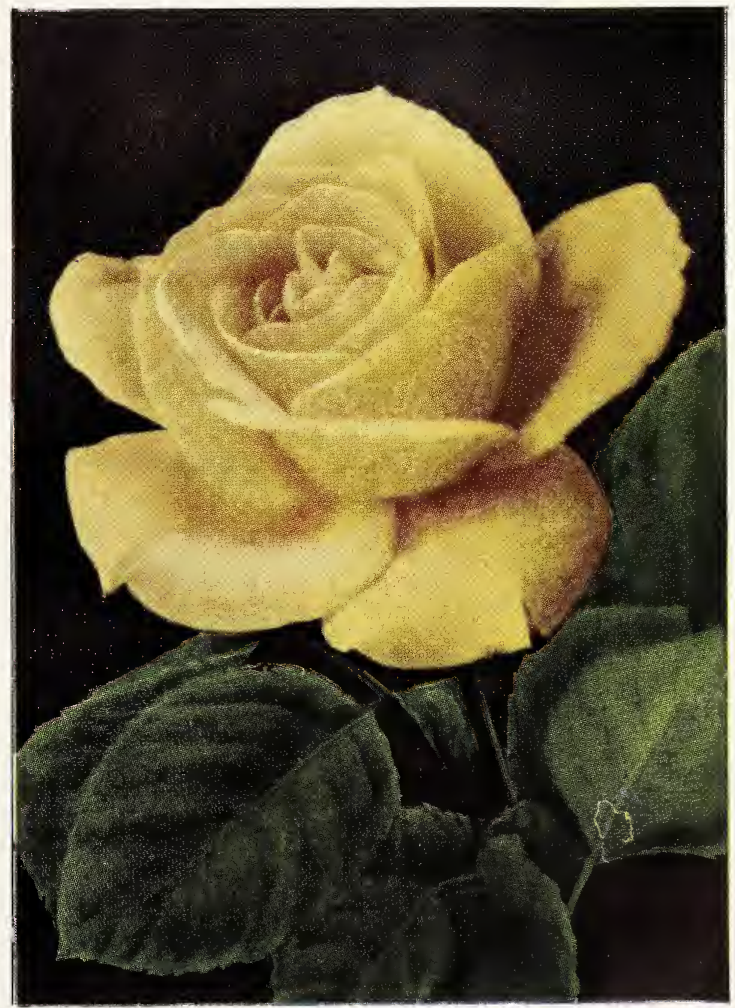

OPHELIA 


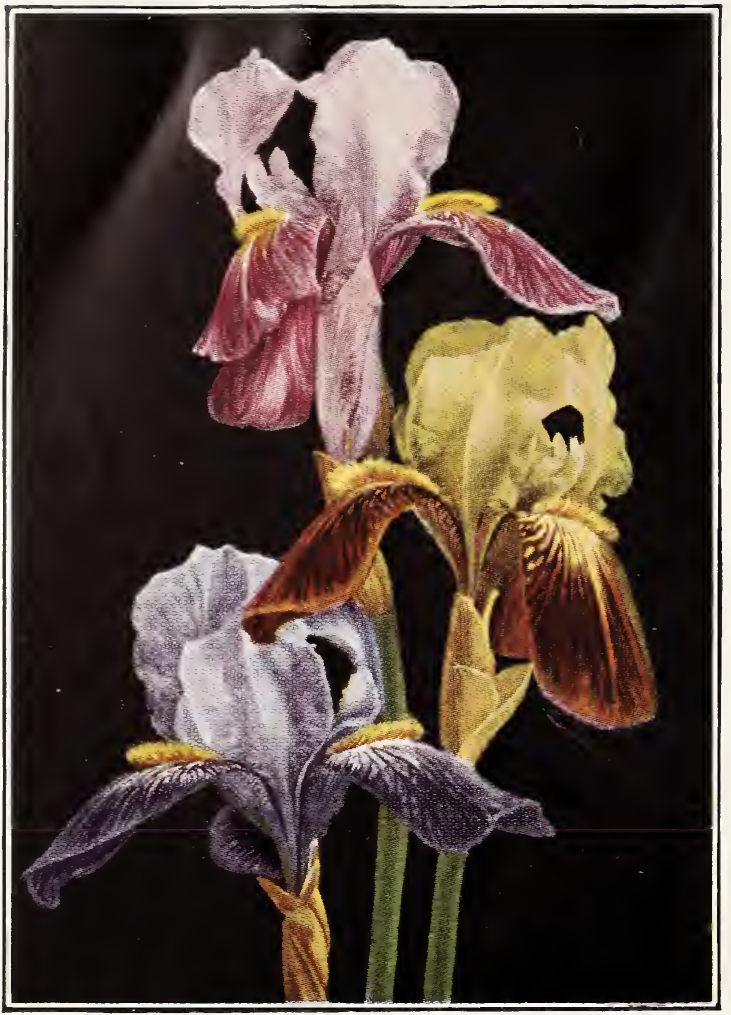

IRIS-(German) Iris germanica

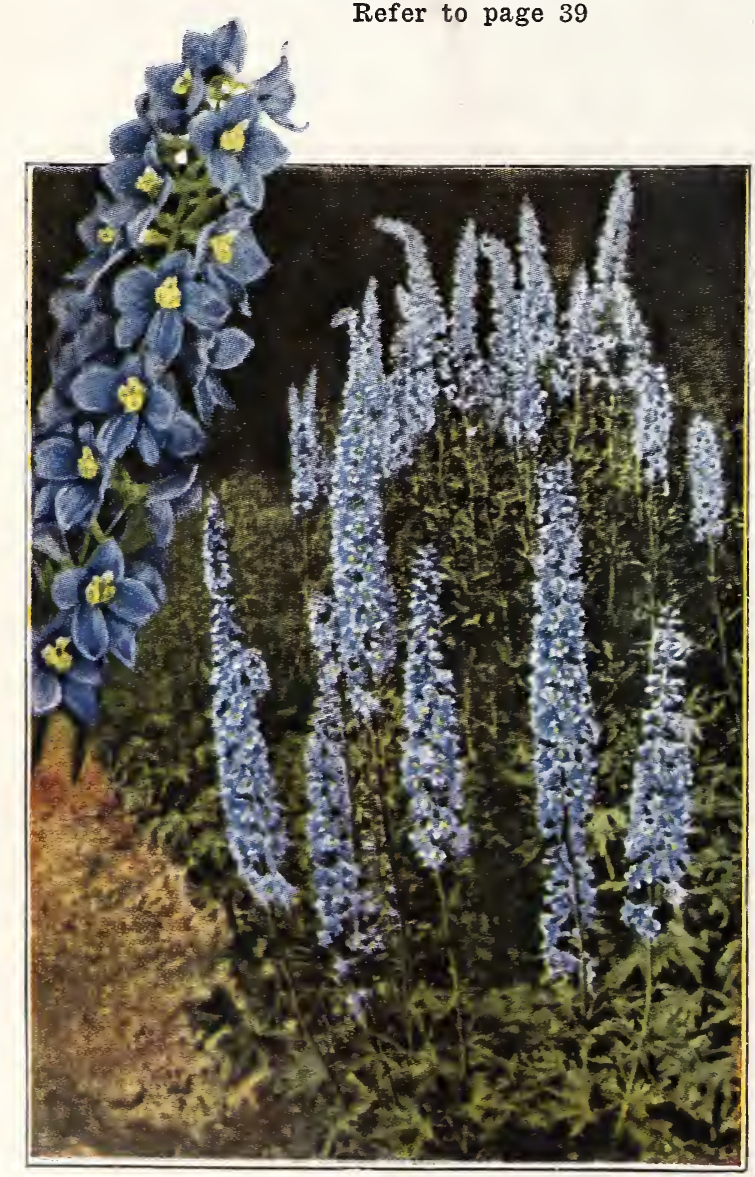

LARKSPUR-Delphinium formosum

Refer to page 37

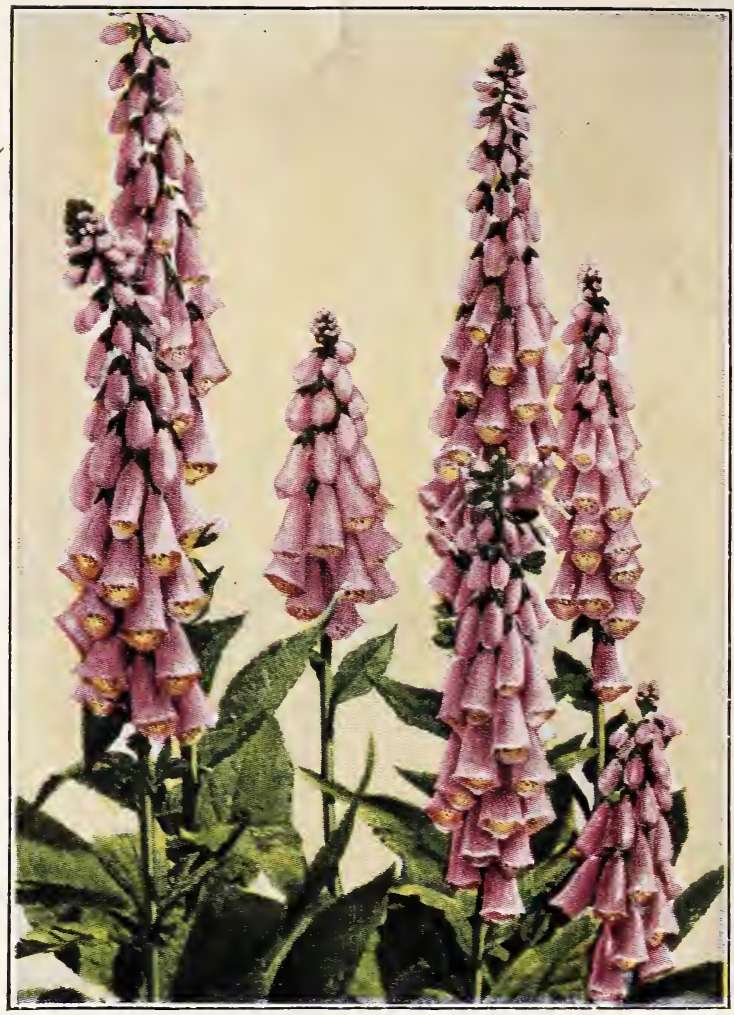

FOXGLOVE-Digitalis purpurea

Refer to page 37

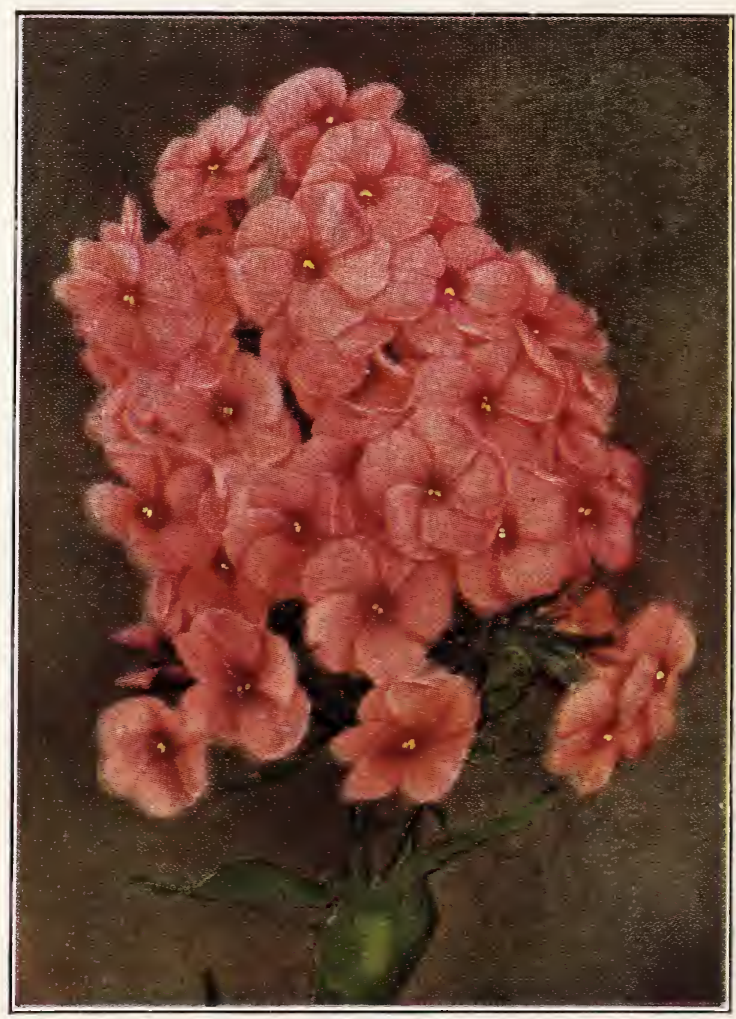

PHLOX-Phlox paniculata var. Refer to page 40 